Florida International University

FIU Digital Commons

FIU Electronic Theses and Dissertations

University Graduate School

7-25-2003

\title{
Characterizing fracture distribution in layered rocks using geographic information system-based techniques
}

Kajari Ghosh

Florida International University

Follow this and additional works at: https://digitalcommons.fiu.edu/etd

Part of the Geology Commons

\section{Recommended Citation}

Ghosh, Kajari, "Characterizing fracture distribution in layered rocks using geographic information systembased techniques" (2003). FIU Electronic Theses and Dissertations. 3932.

https://digitalcommons.fiu.edu/etd/3932

This work is brought to you for free and open access by the University Graduate School at FIU Digital Commons. It has been accepted for inclusion in FIU Electronic Theses and Dissertations by an authorized administrator of FIU Digital Commons. For more information, please contact dcc@fiu.edu. 
FLORIDA INTERNATIONAL UNIVERSITY

Miami, Florida

CHARACTERIZING FRACTURE DISTRIBUTION IN LAYERED ROCKS USING GEOGRAPHIC INFORMATION SYSTEM-BASED TECHNIQUES

A thesis submitted in partial fulfillment of the requirements for the degree of MASTER OF SCIENCE in

GEOLOGY

by

Kajari Ghosh 
To: Dean Arthur W. Herriott

College of Arts and Sciences

This thesis, written by Kajari Ghosh, and entitled Characterizing Fracture Distribution in Layered Rocks Using Geographic Information System-Based Techniques, having been approved in respect to style and intellectual content, is referred to you for judgment.

We have read this thesis and recommend that it be approved.

Grenville Draper

Dean Whitman

Michael R. Gross, Major Professor

Date of Defense: July 25, 2003

The thesis of Kajari Ghosh is approved.

Dean Arthur W. Herriott College of Arts and Sciences

Dean Douglas Wartzok University Graduate School

Florida International University, 2003 


\section{ACKNOWLEDGMENTS}

I am deeply indebted to my mentor and advisor, Dr. Michael Gross, for providing invaluable professional, academic, and personal counsel. Dr. Gross gave me the opportunity to work on such an interesting project and has provided me with the tools one needs to approach a scientific problem. I am sincerely grateful and indebted to the committee members, Dr. Grenville Draper and Dr. Dean Whitman for the ideas I developed during the number of courses I took with them. I thank Diane Pirie, Rosa Necolardes and Bonnie Boddicker for pleasantly providing logistical support. Finally, I would like to express my thanks to all the students at the Florida International University, Department of Earth Sciences for being an essential source of friendship and support. A special recognition of the warm friendship I have shared with the individuals should go to Daniel Davila, Alex Manda, Carlos Molina and Sumanjit Aich. Funding for this research project was provided by the United States Army Research Office, Grant No. DAAD1999-1-0306. 


\section{ABSTRACT OF THE THESIS \\ CHARACTERIZING FRACTURE DISTRIBUTION IN LAYERED ROCKS USING GEOGRAPHIC INFORMATION SYSTEM-BASED TECHNIQUES}

by

Kajari Ghosh

Florida International University, 2003

Miami, Florida

Professor Michael R. Gross, Major Professor

Fractures are discrete planar features that are heterogeneously distributed throughout the earth's upper crust. Methods commonly used to quantify fracture populations typically yield singular values/indexes for the attribute of interest. These values are useful in characterizing the bulk properties of a fracture population, but are unable to address the inherent spatial heterogeneities of the fracture network.

This study explores techniques to map fractures and capture the spatial heterogeneity of fracture networks within a Geographic Information System (GIS). The study was performed on exposures of the intensely fractured Monterey Formation in Santa Barbara, California. Results of the GIS-based spatial analysis provide a framework to (a) quantify the dependence of fracture style on lithology, (b) compare and contrast geometric properties of fracture populations hosted in alternate stratigraphic units, (c) evaluate fracture intensity as a function of proximity to large faults, and (d) quantify geometric properties of fracture networks that impact fluid flow. 


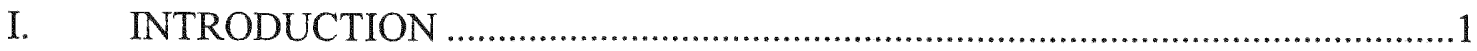

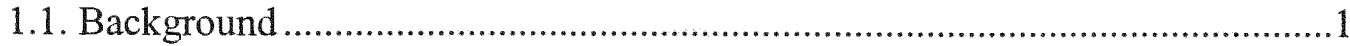

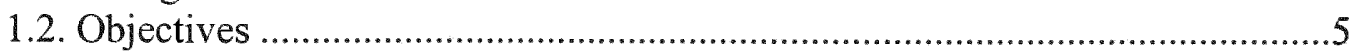

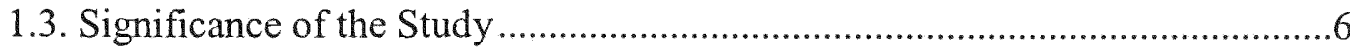

II. GEOLOGIC SETTING AND OUTCROP DESCRIPTION ….............................

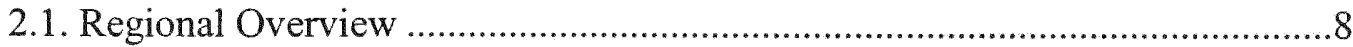

2.2. Monterey Formation Exposures at Arroyo Burro ..........................................11

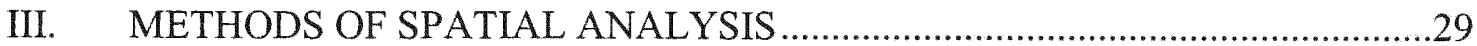

3.1. GIS and Remote Sensing Packages Used ..................................................29

3.2. Transfer of Field Data to Digital Format ........................................................30

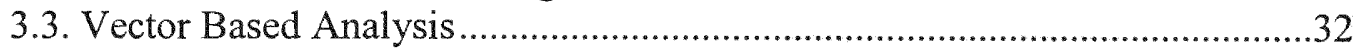

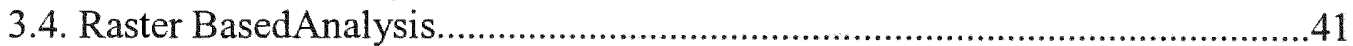

IV. SPATIAL ANALYSIS OF FRACTURED OUTCROPS:

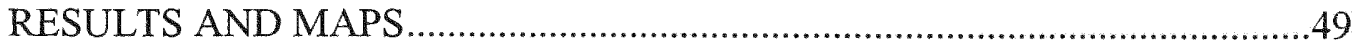

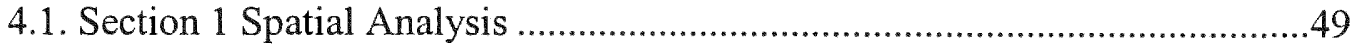

4.2. Section 2 Spatial Analysis ......................................................................

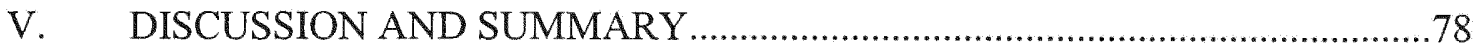

5.1. Comaparison of joints and small faults in alternate layers of Section 1 .........78

5.2. Implications for fluid flow through fracture networks ..................................8

5.3. Dip separation map .................................................................................95

5.4. Fracture intensity as a function of proximity to large faults ..........................96

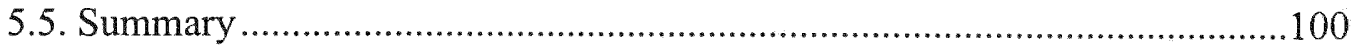

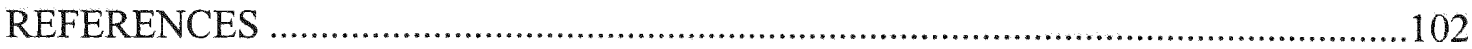




\section{LIST OF TABLES}

TABLE

PAGE

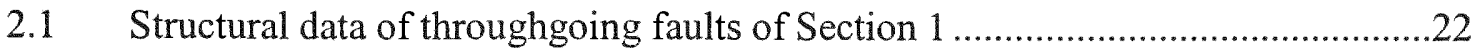

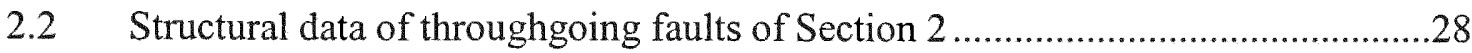

3.1 Root mean square error of control points for the first order polynomial transformation of Section 1 outcrop photograph

3.2 Root mean square error of control points for the second order polynomial transformation of Section 1 outcrop photograph

4.1 Joint spacing statistics within porcellanite units of Section 1 .53

4.2 Small fault spacing statistics within mudstone units of Section 1 .54

4.3 Results of buffer analysis on Section 1 backbones

4.4 Fracture intensity statistics of Section 2 .71

5.1 Summary of fracture spacing statistics at Section 1

5.2 Summary values of coefficient of variation of joints in Section 1 .80

5.3 Summary values of coefficient of variation of small faults in Section 1 .82

5.4 Joint intensity statistics in porcellanite units of Section 1 .83

5.5 Small fault intensity statistics in mudstone units of Section 1 83 


\section{LIST OF FIGURES}

FIGURE

PAGE

1.1a Schematic diagram illustrating hierarchy of joints in layered rocks.....................

$1.1 \mathrm{~b}$ Schematic diagram illustrating the concept of fracture partitioning.......................4

1.1c Map from Gillespie et al., (2001), showing fracture zone .....................................

2.1 Tectonic map of the Western Transverse Ranges and surrounding regions............9

2.2a Stratigraphic column for the Monterey Formation along the western Santa

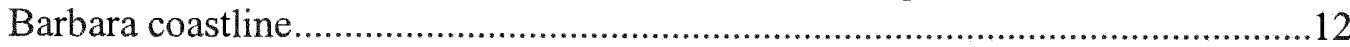

2.2b Measured section of the Monterey Formation at Arroyo Burro Beach .................12

2.3 Location of Arroyo Burro section plotted of Geologic map of Santa Barbara......13

2.4 Location of outcrops plotted on geologic map of Arroyo Burro ...........................15

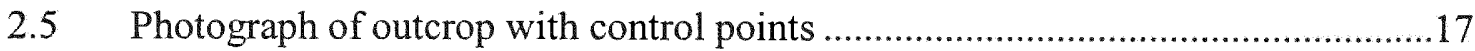

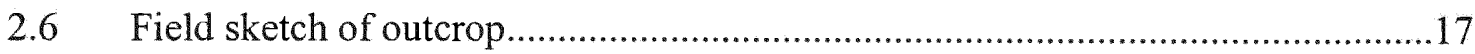

2.7 Cross section showing distribution of normal faults at Arroyo Burro Beach........19

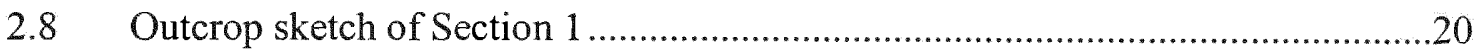

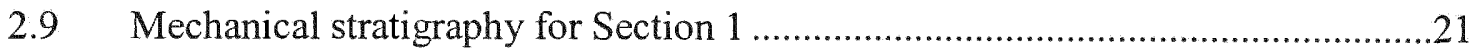

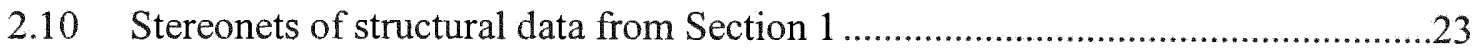

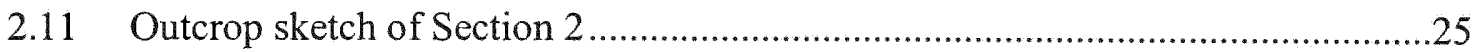

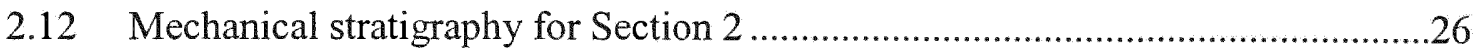

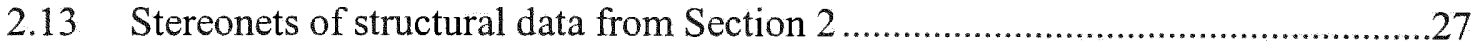

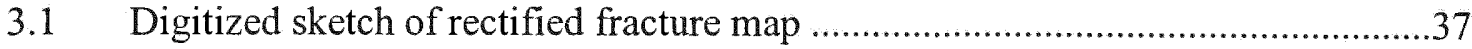

3.2 Schematic diagram of the scanline method of measuring fracture spacing...........37

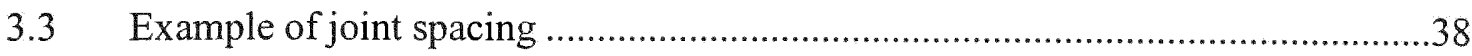


3.4 Illustration of method used for calculating fractal dimension ..............................38

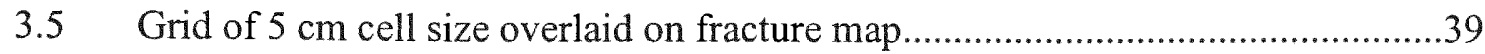

3.6 Example of fracture network with dead-end fracture segments and fracture segments belonging to the backbone

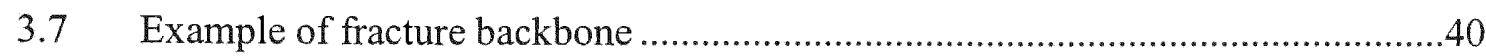

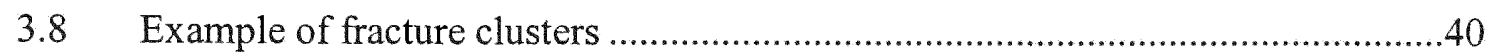

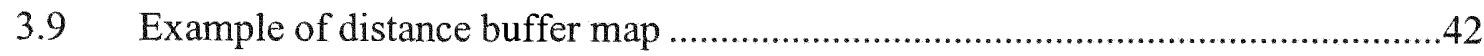

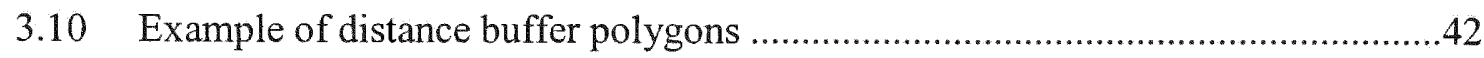

3.11 Schematic diagram illustrating Arc Info "linedensity" routine ............................46

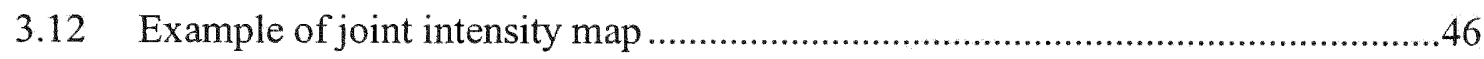

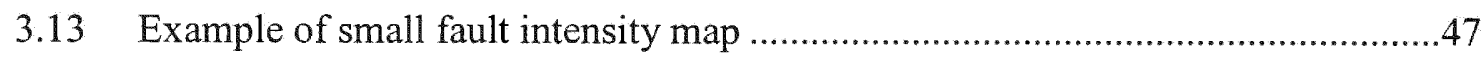

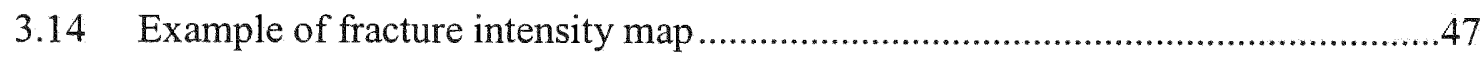

3.15 Sketch illustrating the "summarize zone" function ..............................................48

3.16 Sketch illustrating method of fault displacement measurement ..........................48

4.1 Frequency histograms of joints and small faults at Section 1 ............................50

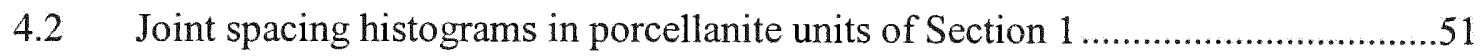

4.3 Small fault spacing histograms in mudstone units of Section 1 ..........................52

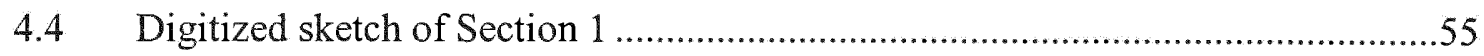

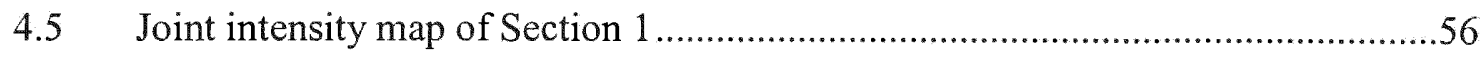

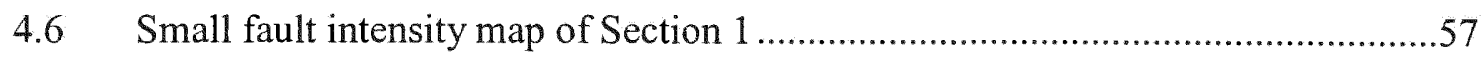

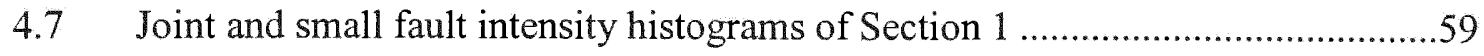

4.8 Fractal dimension plots for joints and small faults of Section 1 .........................60

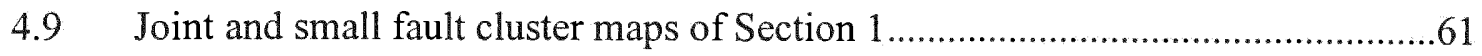


4.10 Fracture cluster maps of Section 1

4.11 Fracture backbone map of Section 1 with all fractures......................................64

4.12 One cm buffer zone mapped around Section 1 backbones ...................................65

4.13 Two cm buffer zone mapped around Section 1 backbones .................................66

4.14 Three cm buffer zone mapped around Section 1 backbones .............................67

4.15 Four $\mathrm{cm}$ buffer zone mapped around Section 1 backbones .................................68

4.16 Five cm buffer zone mapped around Section 1 backbones.................................69

4.17 Fault map and fault dip separation map of Section 1.........................................

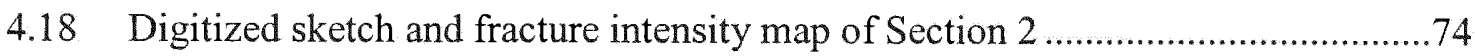

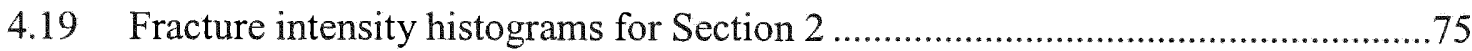

4.20 Plots of average fracture intensity as a function of distance from nearest big

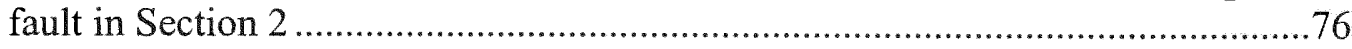

4.21 Histograms representing average fracture intensity as a function of distance

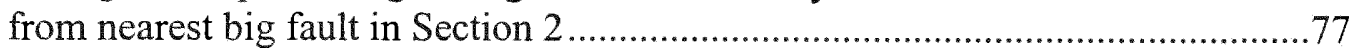

5.1 Graph showing confidence intervals for the coefficient of variation ....................81

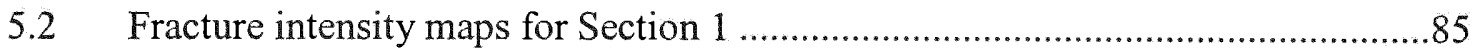

5.3 Joint intensity map superimposed on small fault intensity map of Section 1........86

5.4 Table and histogram of percent of total area covered by each fracture type .........87

5.5 Schematic diagram illustrating concept of percolation theory ...............................90

5.6 Schematic diagram illustrating fault-fracture mesh .........................................92

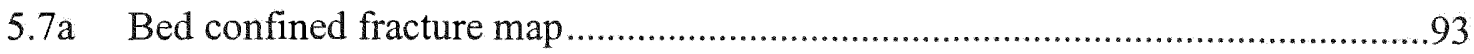

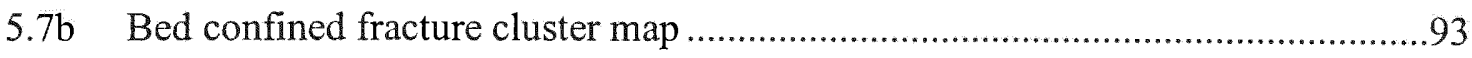

5.8 Schematic diagram illustrating fault-fracture mesh inferred from this study ........94 
5.9 Plots of average fracture intensity in mudstone units as a function of distance from nearest big fault in Section 2

5.10 Histograms representing average fracture intensity in mudstone units as a function of distance from nearest big fault in Section 2 


\section{CHAPTER 1}

\section{INTRODUCTION}

\subsection{Background}

Fractures are among the most common structures in the earth's upper crust, where brittle deformation predominates as a result of relatively low temperatures and pressures (Engelder, 1993). The general term "fracture" describes any planar discontinuity (joint, fault or vein) of deformational origin. Fractures are divided into two main groups based on their sense of motion: joints are extensional, opening-mode (mode I) fractures with displacement perpendicular to the fracture plane, whereas faults (modes II and III) display evidence of significant shear displacement (Pollard and Aydin, 1988). Fractures form by the release of elastic strain energy in response to an applied force (Lawn, 1993). Thus, fractures and their associated structures may serve as indicators of tectonic stress and strain (Angelier, 1994; Gross and Engelder, 1995). The style (i.e., faulting versus jointing), extent of development (e.g., density, dimensions) and orientation of fractures depend on a number of factors including stress magnitude, stress field orientation, rock fabric, lithology and mechanical properties of the rock. As a consequence of these temporally and spatially varying factors, the distribution of fractures in rock is highly heterogeneous.

In layered sedimentary rocks, fractures are often confined to discrete stratigraphic intervals referred to as "mechanical layers" or "mechanical units" (Narr and Suppe, 1991; Gross et al., 1995). A mechanical unit is defined by the common structural style - in this case brittle fractures - that characterizes deformation within that interval of rock. Thus, a 
mechanical unit may consist of several stratigraphic beds that share the same population of fractures. Most mechanical layer boundaries are bedding contacts, especially contacts separating beds of contrasting lithologies (Underwood et al. 2003). Fractures confined to one mechanical layer are termed "single layer" or "bed-confined" fractures, whereas fractures that traverse multiple mechanical layers are referred to as "multi-layer" or “throughgoing" fractures (Fig.1a) (Bahat, 1988; Becker and Gross, 1996). The heights (cross sectional trace lengths) of bed-confined fractures are often constrained by the mechanical unit thickness. In fact, many field studies report a linear correlation between joint spacing and bed thickness, such that thinner beds have more closely-spaced joints than thicker beds (Price 1966; Narr and Suppe, 1991; Gross, 1993; Bai and Pollard, 2000). In addition to bed thickness, joint spacing depends upon lithology and strain magnitude, the latter often being related to structural position such as proximity to fracture zones and relation to fold geometry (Becker and Gross, 1996; Hennings et al., 2000).

Differences in mechanical properties may lead to the development of different fracture styles in adjacent lithologies (Fig.1b). For example, regional extension of the Monterey Formation of California since the middle Miocene led to the coeval development of joints in competent lithologies (cherts, porcellanites, dolostones) and faults in less competent mudstones (Gross, 1995). Wilkins (1999) observed a similar relationship in clastic rocks of the Glen Canyon Sandstone, Utah, where joints predominate in sandstone beds and small faults are restricted to shale horizons. The dependence of fracture style on lithology, referred to as "fracture partitioning", has important implications for fluid flow through fractured bedrock. Faults and joints differ 
in terms of their roughness, kinematics, aperture, mineralization and gouge/breccia thickness, all important parameters that control the hydraulic conductivity of a fracture (Smith and Schwartz; 1984, Long and Witherspoon, 1985; Brown, 1987; Priest, 1993; Odling, 1995). Thus, mechanical units of different fracture types will likely display markedly different behavior in terms of fluid flow properties.

Many techniques have been developed to characterize rock masses by quantifying fracture attributes such as spacing (and its inverse, fracture density), length, aperture, connectivity and fractal dimension (Priest and Hudson, 1976; LaPointe and Hudson, 1985; Narr and Suppe, 1991; Gillespie et al., 1993; Wu and Pollard, 1995; Renshaw, 1997; Mauldon et al., 2001; La Pointe, 2002; Peacock et al., 2003). Regardless of the approach, results are typically quantified in terms of a bulk value (1-D, 2-D or 3-D) for the region of interest (e.g. median fracture spacing and its standard deviation) or alternatively as histograms of a specific fracture attribute (e.g., length, aperture or spacing). However, these methods are unable to characterize the spatial variability of the fracture networks within the region of analysis, an issue of extreme importance due to the aforementioned heterogeneous nature of fracture populations. We illustrate this point with the fracture trace map of Gillespie et al. (2001) shown in Figure 1c. One dimensional scanlines (e.g., Priest and Hudson, 1976; Narr and Suppe, 1991) or twodimensional surveys (Wu and Pollard, 1995; Mauldon et al., 2001) designed to measure fracture density yield only bulk values for the entire area. For example the Priest and Hudson (1976) 1-D scanline method applied to a traverse along X-X' (Fig. 1c) yields a median fracture spacing of 1.15, whereas the $\mathrm{Wu}$ and Pollard (1995) 2-D method 

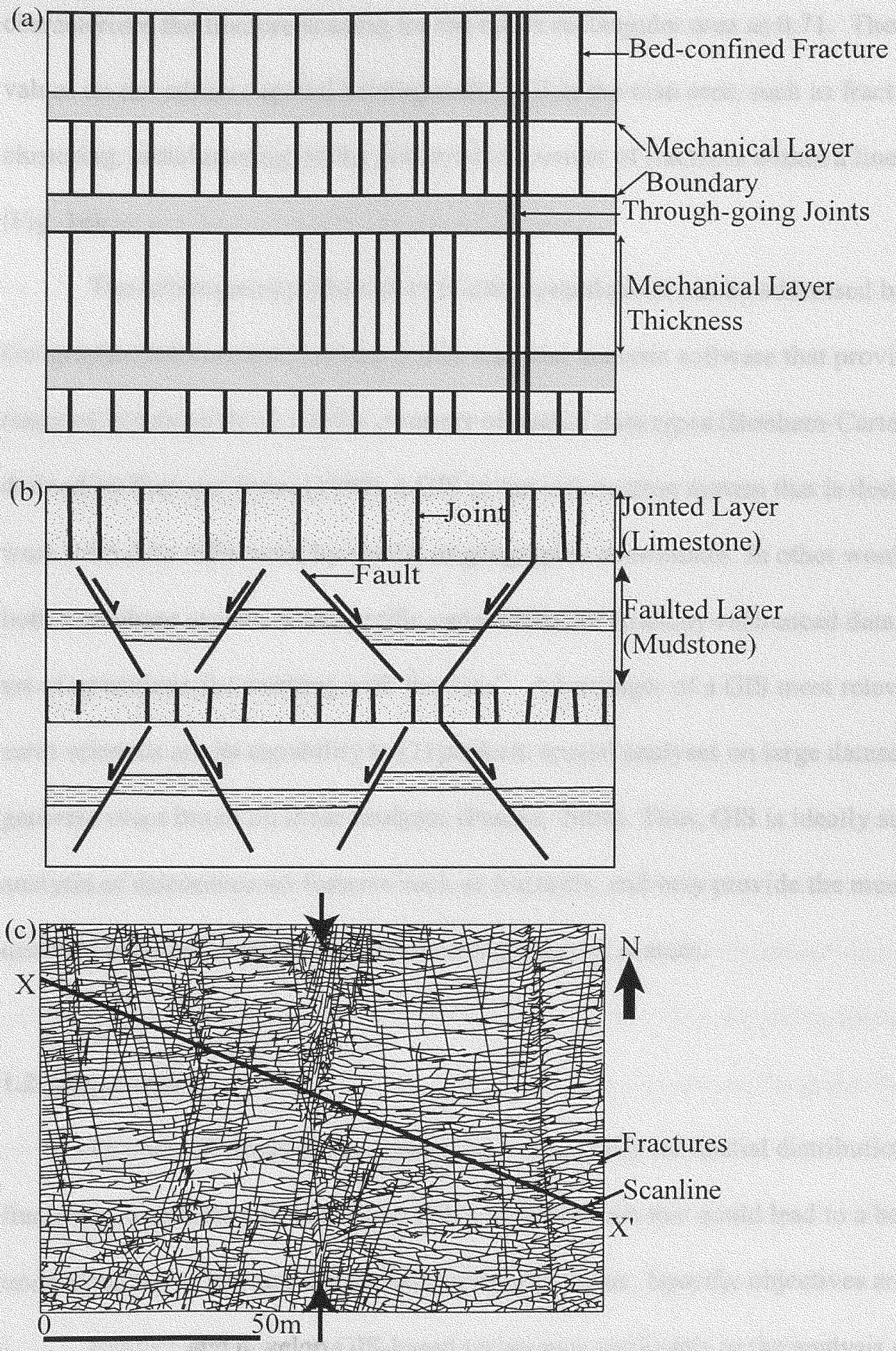

Fig. 1 (a) Schematic diagram illustrating hierarchy of joints in layered rocks. (b) Schematic diagram illustrating the concept of fracture partitioning, whereby joints and faults are confined to different lithologies. (c) Map from Gillespie et al., 2001. The fracture zone is indicated by black arrows. 
characterizes the fracture spacing for the entire rectangular area as 0.71 . These bulk values do not address spatial heterogeneity within the map area, such as fracture clustering, anticlustering, or the preferred alignment of fractures within a linear zone (Fig. 1c).

The heterogeneity inherent in fracture populations can be addressed by using Geographic Information Systems (GIS), a spatial analysis software that provides a broad range of functionality to handle a variety of spatial data types (Bonham-Carter, 1994). As defined by Star and Estes (1990), a GIS is "an information system that is designed to work with data referenced by spatial or geographic coordinates. In other words, a GIS is both a database system with specific capabilities for spatially-referenced data, as well as a set of operations for working with the data". Advantages of a GIS most relevant to the earth sciences are its capability to (1) perform spatial analyses on large datasets and (2) generate maps based on these analyses (Paulus, 2000). Thus, GIS is ideally suited for the analysis of discontinuous features such as fractures, and may provide the means to quantify important structural trends in fractured rock masses.

\subsection{Objectives}

The overall goals of my research are to quantify the spatial distribution of fractures using GIS, and to explore GIS-based methods that could lead to a better understanding of fracture distribution in layered rocks. Specific objectives are to: i. Explore and develop GIS-based techniques applicable to the analysis of twodimensional fracture maps. 
ii. Evaluate the spatial heterogeneity of fracture systems in terms of fracture intensity, fractal dimension and fault displacement gradients.

iii. Establish the parametric differences between joint and fault populations hosted in alternate layers of the same rock formation.

iv. Investigate effects of mechanical stratigraphy on the spatial distribution of fractures in layered rocks.

v. Evaluate the relationship between fracture intensity and proximity to large faults.

vi. Evaluate geometric properties of fracture networks that impact fluid flow, such as fracture connectivity and percolation clusters.

\subsection{Significance of the study}

Fracture distribution directly affects the hydrologic and mechanical properties of rock. Fractures may serve as conduits for fluid flow or may act as barriers to flow. For example an interconnected network of opening-mode fractures can transform an otherwise impermeable rock into a viable aquifer or economic hydrocarbon reservoir. Fractures also play a major role in landscape evolution. Thus, a good understanding of fracture geometry, distribution and fracture mechanism is critical for groundwater modeling and evaluating rock mass stability.

This study develops appropriate techniques to quantify the spatial distribution of fractures. It also explores the geologic factors that control these spatial variations, such as stratigraphic layering and structural position. The permeability of a fractured rock mass is controlled by the extent to which the individual fractures are linked to form a continuous fracture network through the rock. Thus, the connectivity of a fracture system 
determines the effective permeability of the rock mass, which in turn is dependent on the fracture geometry and distribution. The analytical techniques developed in this study may provide insight on the two dimensional connectivity of fracture networks. 


\section{CHAPTER 2}

\section{GEOLOGIC SETTING AND OUTCROP DESCRIPTION}

\subsection{Regional overview}

The field area for this study is located in the Santa Barbara basin of central coastal California, which is part of the Western Transverse Ranges, a crustal block situated west of the San Andreas Fault (Fig. 2.1).

\subsubsection{Tectonic setting}

In early Cenozoic time the California borderland was a convergent margin, as the Farallon plate subducted beneath the North American plate (Atwater, 1989). During the middle Cenozoic, the Pacific plate collided with the North American plate initiating the San Andreas Transform Fault system. The Santa Barbara basin is one of a series of extensional basins that developed along the California borderland at the beginning of the Miocene (Howell et al., 1980; Clark et al., 1994). Paleomagnetic data suggests that the Santa Barbara basin has undergone $90^{\circ}$ of clockwise rotation since the early Miocene (Crouch, 1979; Luyendyk et al., 1980; Hornafius, 1985). The tectonic stress regime along the California borderland switched from transtension in the Miocene to transpression in the early Pliocene (Yerkes, 1985; Clark et.al., 1991; Nicholson et al., 1992), most likely the consequence of changes in the relative plate motion between the Pacific and North American plates at 8-6 Ma (Argus and Gordon, 2001). 


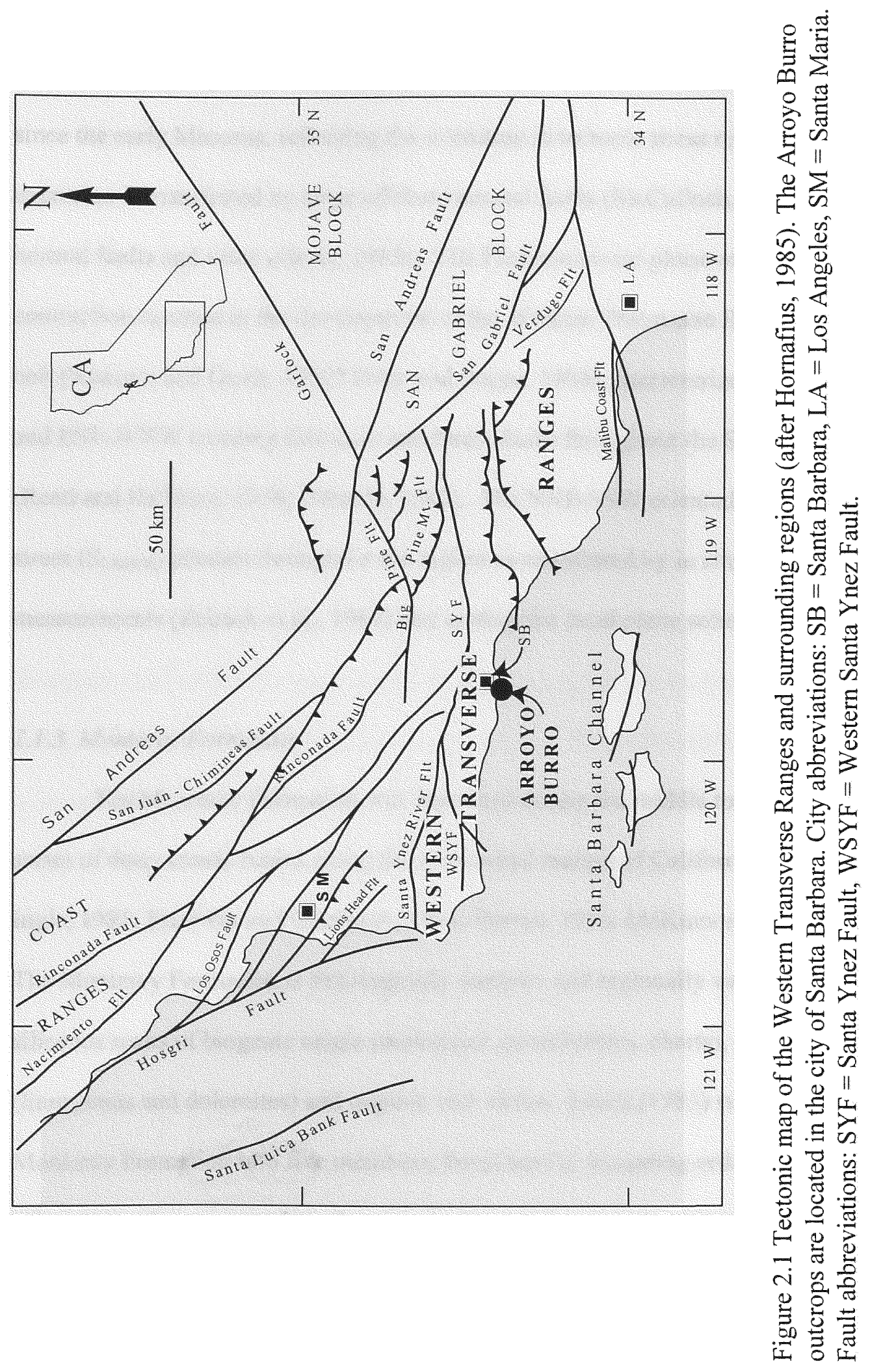




\subsubsection{Structural style}

Two main phases of deformation are recorded in the Western Transverse Ranges since the early Miocene, reflecting the evolution in tectonic stress regimes. Miocene extension is manifested by large offshore normal faults (McCulloch, 1989) and mesoscale normal faults and veins (Gross, 1995). The Pliocene-recent phase of NNE-SSW contraction resulted in the development of the Western Transverse Ranges fold and thrust belt (Namson and Davis, 1990; Shaw and Suppe, 1994), characterized by a series of E-W and ESE-WNW trending fold axes and thrust faults throughout the Santa Barbara basin (Reed and Hollister, 1936; Dibblee, 1982). The NNE-SSW oriented maximum horizontal stress ( $\left.\mathrm{S}_{\mathrm{HMAX}}\right)$ persists throughout the region as manifested by in situ stress measurements (Zoback et al., 1987) and earthquake focal plane solutions (Yerkes, 1985).

\subsubsection{Monterey Formation}

The Monterey Formation was deposited during the middle to late Miocene in a series of deep anoxic basins along the continental margin of California (Issacs, 1980; Ingle, 1981; Pisciotto and Garrisson, 1981; Barron, 1986; McKinnon, 1989; Behl, 1999). The Monterey Formation is lithologically complex and regionally variable, consisting of siliceous rocks of biogenic origin (diatomites, porcellanites, cherts), carbonates (limestones and dolomites) and organic-rich shales. Isaacs (1983) subdivided the Monterey Formation into five members, listed here in ascending order: the lower calcareous-siliceous member, the organic phosphatic marl member, the transitional marlsiliceous member, the upper calcareous-siliceous member and the clayey siliceous 
member (Fig. 2.2a). Stratigraphic thicknesses of the Monterey Formation range from $400 \mathrm{~m}$ along the Santa Barbara coastline to $1100 \mathrm{~m}$ along Santa Maria coastline.

Despite its relatively young age the Monterey Formation is intensively deformed, due in large part to its deposition and subsequent burial adjacent to an active plate boundary. Many early extensional structures in the Monterey Formation were reactivated and/or inverted during the later phase of regional contraction (McIntosh et al., 1991; Gutiérrez-Alonso and Gross, 1997). The style of structural deformation within the Monterey Formation reflects the overall thin-skinned tectonics of the larger fold-thrust belt, and is characterized by fault-related folds at many scales (Namson and Davis, 1990; Gutiérrez-Alonso and Gross, 1997). Thin clay-rich layers served as detachment horizons, resulting in disharmonic folding within the formation. Although fracturing took place throughout its history, the most intense brittle deformation in the Monterey Formation occurred in response to Pliocene-recent shortening. The NNE-SSW shortening resulted in extension parallel to the regional fold axes. In the Monterey Formation this alongstrike extension was accommodated by the development of joints, veins and normal faults (Belfield et al., 1983; Narr and Suppe, 1991; Gross and Engelder, 1995).

\subsection{Monterey Formation exposures at Arroyo Burro}

\subsubsection{General overview}

At Arroyo Burro Beach Park within the city of Santa Barbara, a 91 meter thick stratigraphic section of the Monterey Formation is repeatedly exposed over a distance of 2 kilometers (Figs. 2.2b, 2.3); (Hornafius, 1994). The repetition of the section is due to tectonic folding and faulting. At Arroyo Burro structural shortening is accommodated by 


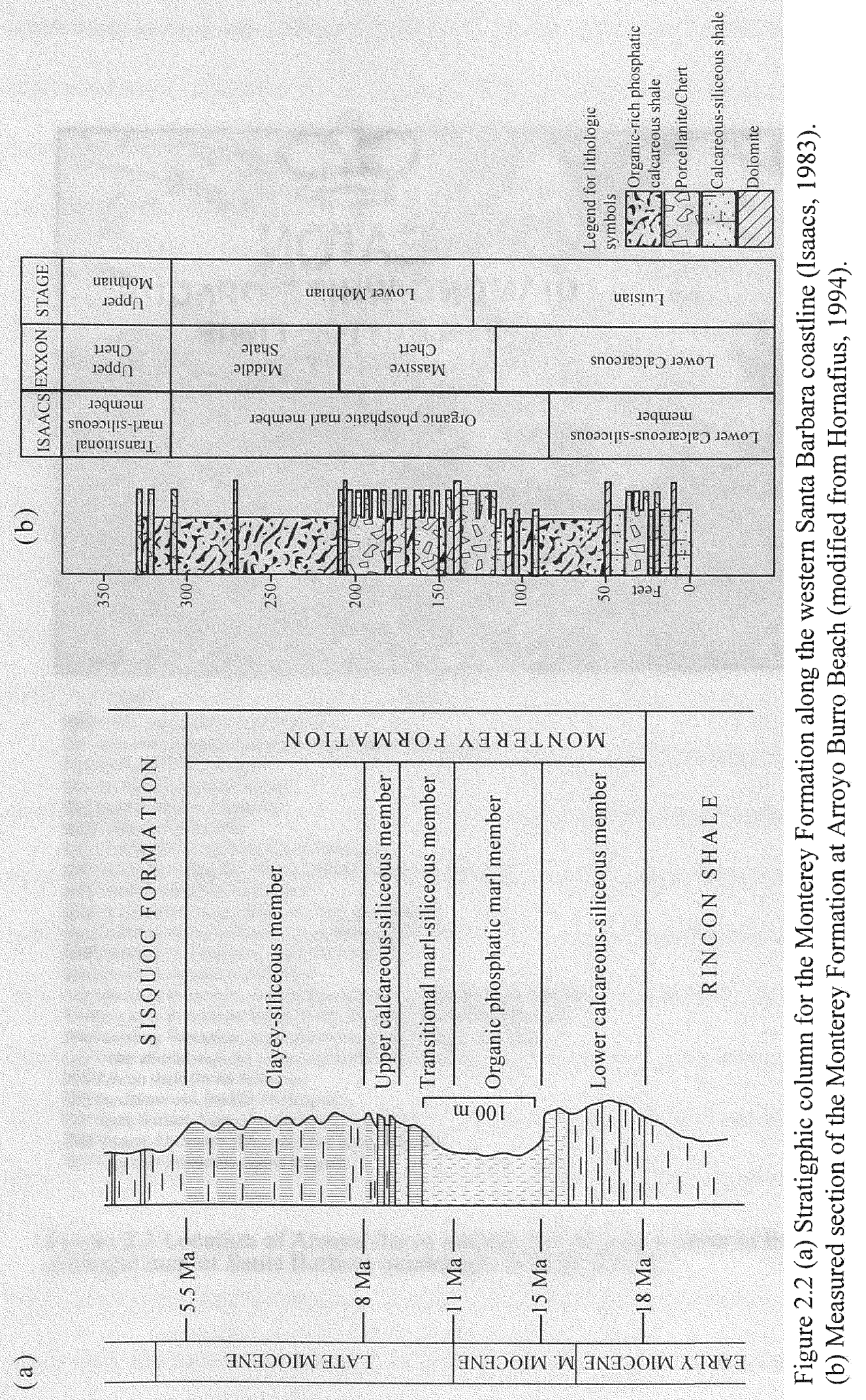




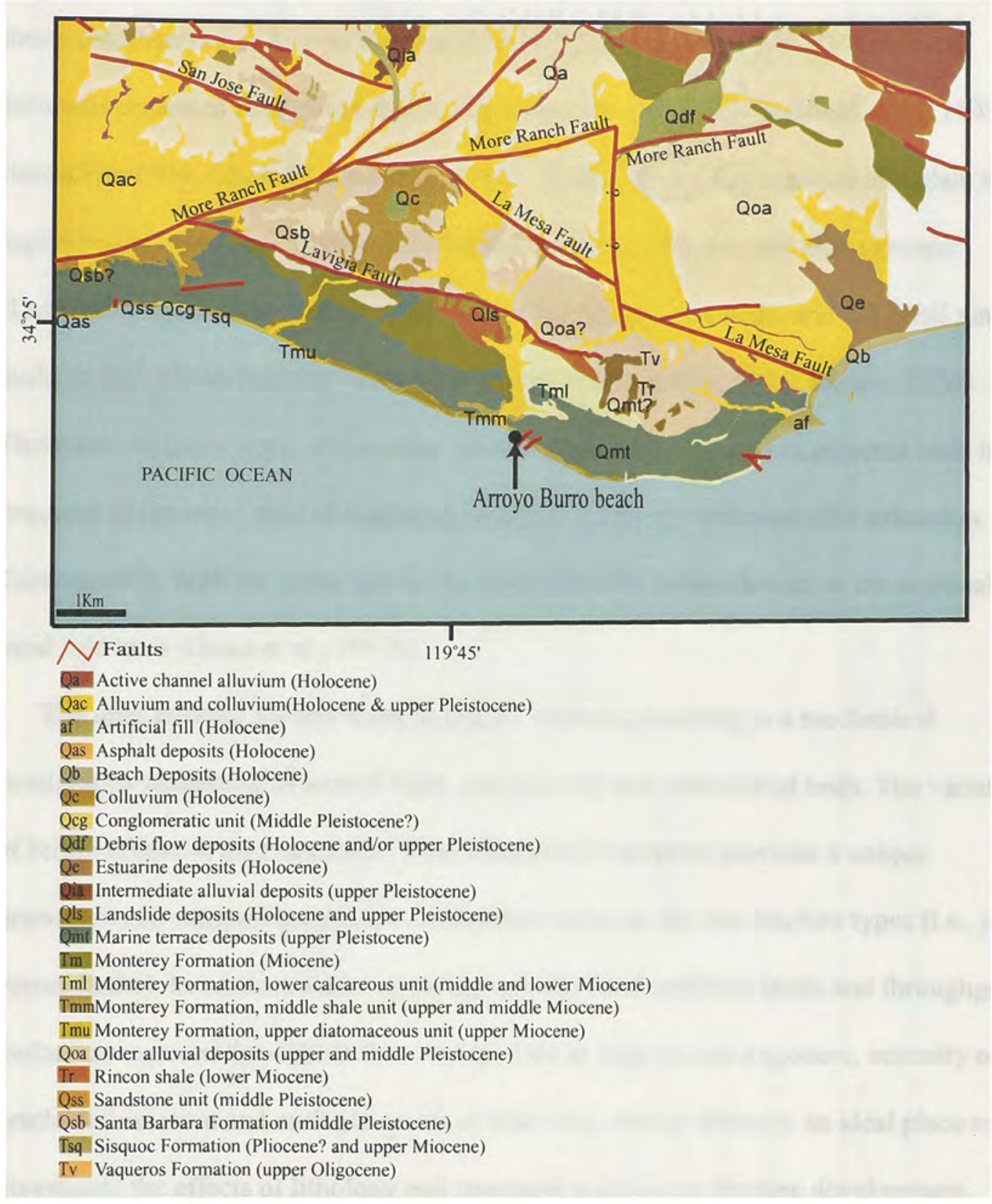

Figure 2.3 Location of Arroyo Burro section plotted on a portion of the geologic map of Santa Barbara quadrangle (USGS, 2001). 
multi-layer flexural slip folding (Gross et al., 1997b). The folds trend NW-SE with subhorizontal axes, reflecting NE-SW directed regional shortening. Among the large structures observed at Arroyo Burro are throughgoing tar-filled breccia zones and dolomite-cemented fault zones that traverse the entire cliff face (Belfield et al., 1993; Hornafius, 1994; Eichhubl and Boles, 1998). Bed-confined fractures are abundant within exposures of the organic phosphatic marl member, and fall into two main groups:

(1) opening-mode joints and veins in dolostone and siliceous beds, and (2) small normal faults in phosphatic-rich mudstone beds (Gross and Engelder, 1995; Sibson, 1996). These two different types of fractures - joints and faults - formed in adjacent beds in response to the same applied boundary conditions, namely strike-parallel extension. Consequently, both the joints and faults strike NE-SW, perpendicular to the regional and local fold axes (Gross et al., 1997b).

The area selected for this study is highly fractured resulting in a mechanical stratigraphy consisting of jointed beds, faulted beds and unfractured beds. The variation of brittle failure in alternate beds of the Monterey Formation provides a unique opportunity to compare parametric differences between the two fracture types (i.e., joints versus faults). In addition faults at multiple scales (bed confined faults and throughgoing faults) are exposed throughout the outcrop. Due to high quality exposure, intensity of brittle deformation and multiple scales of fractures, Arroyo Burro is an ideal place to investigate the effects of lithology and structural position on fracture development.

Two outcrops of the organic phosphatic marl member exposed at Arroyo Burro were selected for detailed analysis. Section 1 is located approximately $1 \mathrm{~km}$ east of the entrance to the park on the NE limb of a small anticline (Fig. 2.4). Section 2 is 


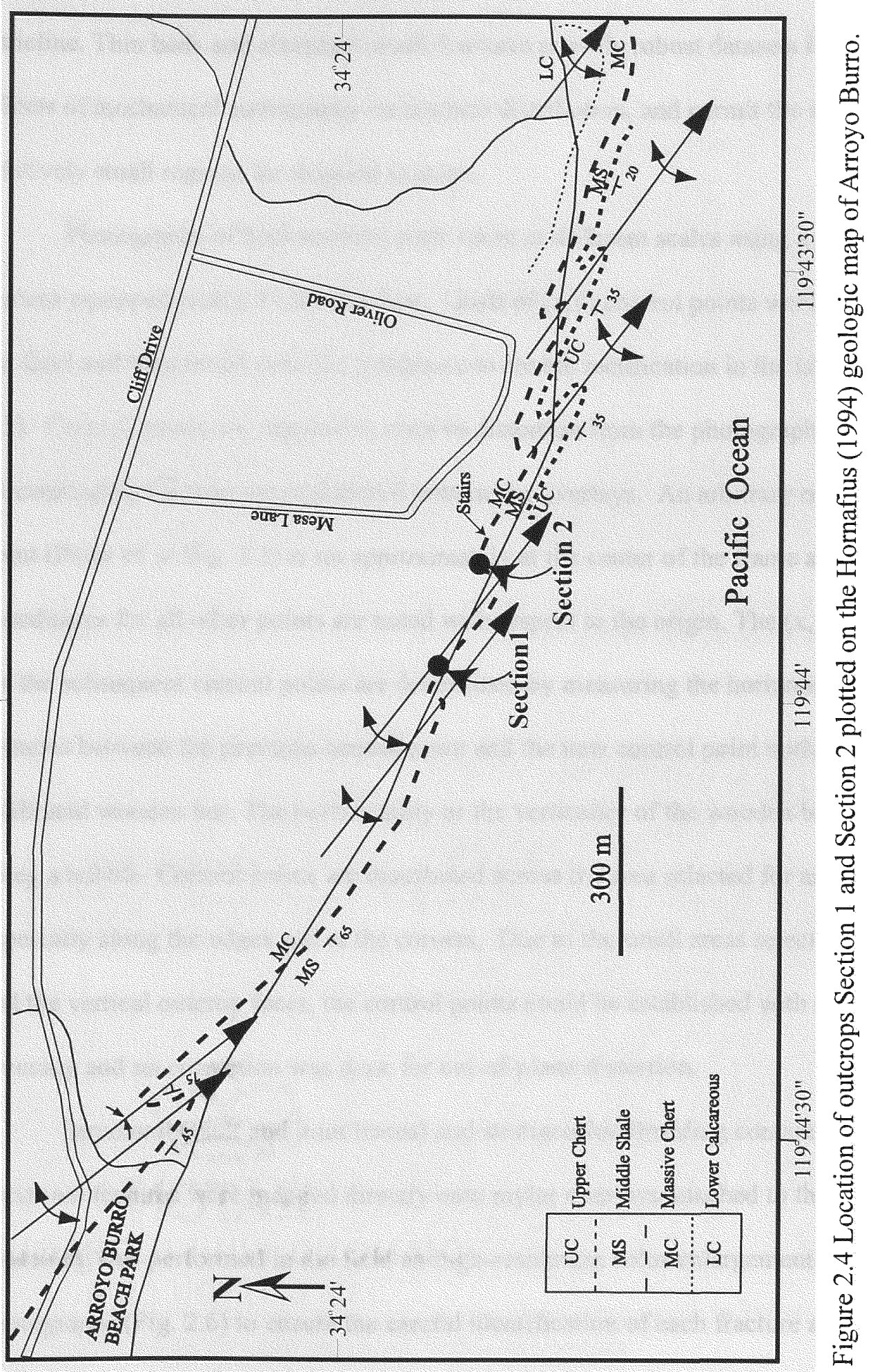


approximately 170 meters to the SE of Section 1 within the hinge zone of the adjacent anticline. Thin beds and abundant small fractures provide robust datasets for evaluating effects of mechanical stratigraphy on fracture distribution, and permit the selection of relatively small regions for detailed analysis.

Photographs of both sections were taken at different scales using a Pentax ZX-10 camera equipped with a 35-80 mm lens. Grids of $(x, y)$ control points were measured in the field and transferred onto the photobase to enable rectification in the laboratory (Fig. 2.5). Control points are required to remove distortion from the photographs and their corresponding fracture maps sketched onto mylar overlays. An arbitrary origin control point (Point \#1 in Fig. 2.5) is set approximately at the center of the frame and the (x,y) coordinates for all other points are noted with respect to the origin. The $(x, y)$ coordinates for the subsequent control points are determined by measuring the horizontal and vertical distance between the previous control point and the new control point with a straight edge calibrated wooden bar. The horizontality or the verticality of the wooden bar is ensured using a bubble. Control points are distributed across the area selected for analysis, especially along the edges and at the corners. Due to the small areas selected for analysis and the vertical outcrop faces, the control points could be established with considerable accuracy and no correction was done for out-of-plane distortion.

Structural (fault and joint traces) and stratigraphic (bedding contacts, marker horizons) features were mapped directly onto mylar overlays attached to the photographs. Sketching was performed in the field on high-resolution color enlargements of the photographs (Fig. 2.6) to ensure the careful identification of each fracture and its precise positioning on the sketch. Overall sketches of each exposure were drawn in order to 


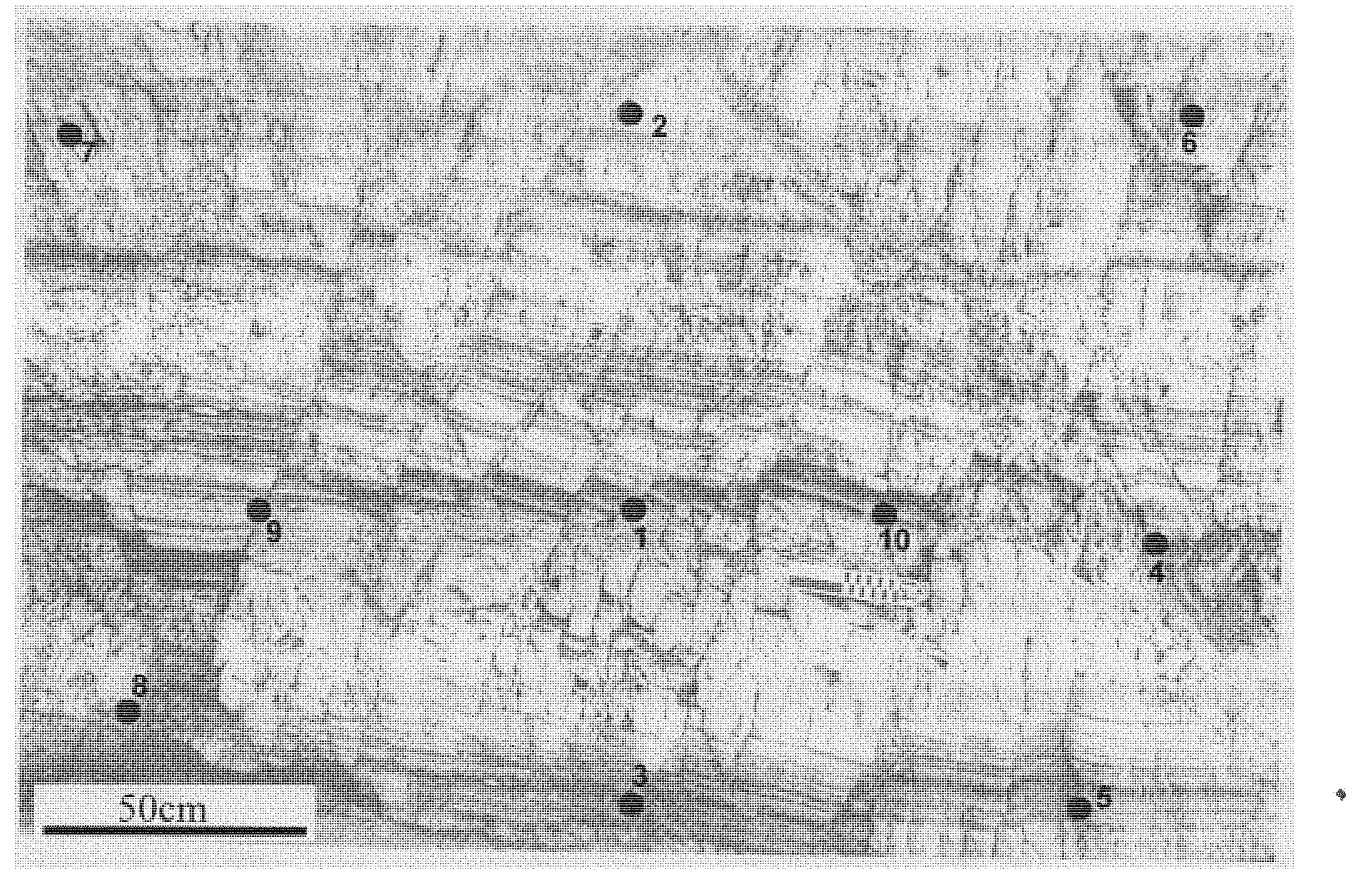

Fig. 2.5 Photograph of outcrop with "control points". Control point \#1 is chosen as the arbitrary origin of the coordinate system and point \#2 and \#3 are aligned vertically with respect to $\# 1$.

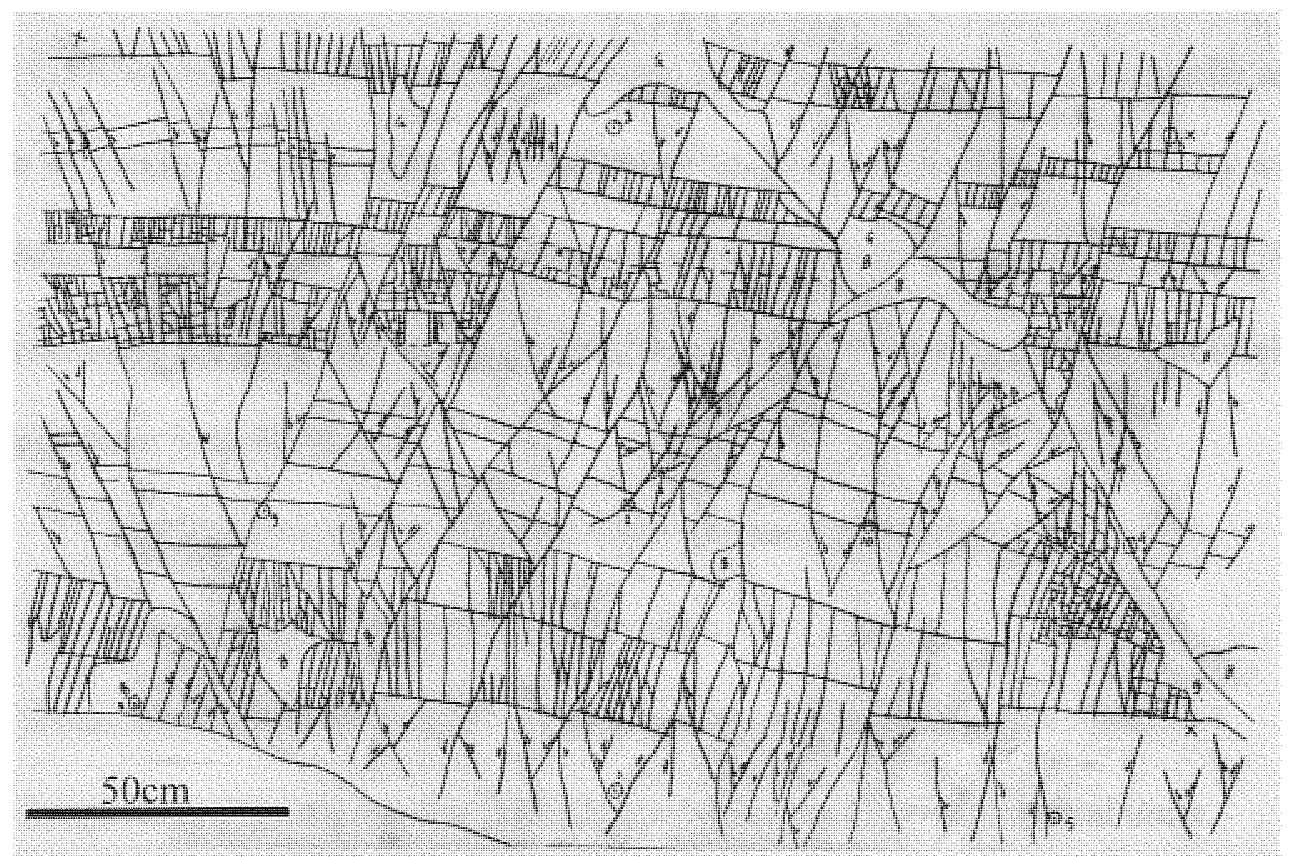

Fig. 2.6 Field sketch drawn on mylar overlay of photograph in Figure 2.5. Control points are also transferred to the field sketch. 
provide geologic context for the smaller areas selected for quantitative spatial analysis.

Field data measured at each section include orientations of bedding, stratigraphic sections (lithology, bed thickness), and the orientations of faults and joints.

\subsubsection{Section 1}

Section 1 is found within the SE portion of the cross section presented in Gross et al. (1997b) (Fig. 2.7). Gross et al. (1997) divided the section into 19 mechanical units, capped at the top by a clay layer that served as a structural detachment during flexuralslip folding. The strike section reveals throughgoing normal faults cutting across multiple beds (Fig. 2.7). Within this section, alternating beds of organic-rich mudstone and siliceous porcellanites contain bed-confined normal faults and joints, respectively. The overall sketch for Section 1 encompasses mechanical units 7 through 17 of Gross et al. (1997b), whereas the subregion selected for detailed analysis, a rectangular area 240 $\mathrm{cm} \times 155 \mathrm{~cm}$, includes units 7 through 15 (Fig. 2.8). Mechanical stratigraphy within the subregion was further divided into finer mechanical units for this study (Fig. 2.9). Bed thicknesses for porcellanites range from 6 to $15 \mathrm{~cm}$, whereas mudstone bed thicknesses range from 9 to $40 \mathrm{~cm}$.

Three main types of fractures were observed in Section 1:

1. Joints mostly confined to porcellanite units.

2. Small normal faults confined to organic-rich mudstone units.

3. Large throughgoing normal faults that traverse multiple mechanical units.

(See Fig. 2.8 and the list of 16 large faults in Table 2.1). 


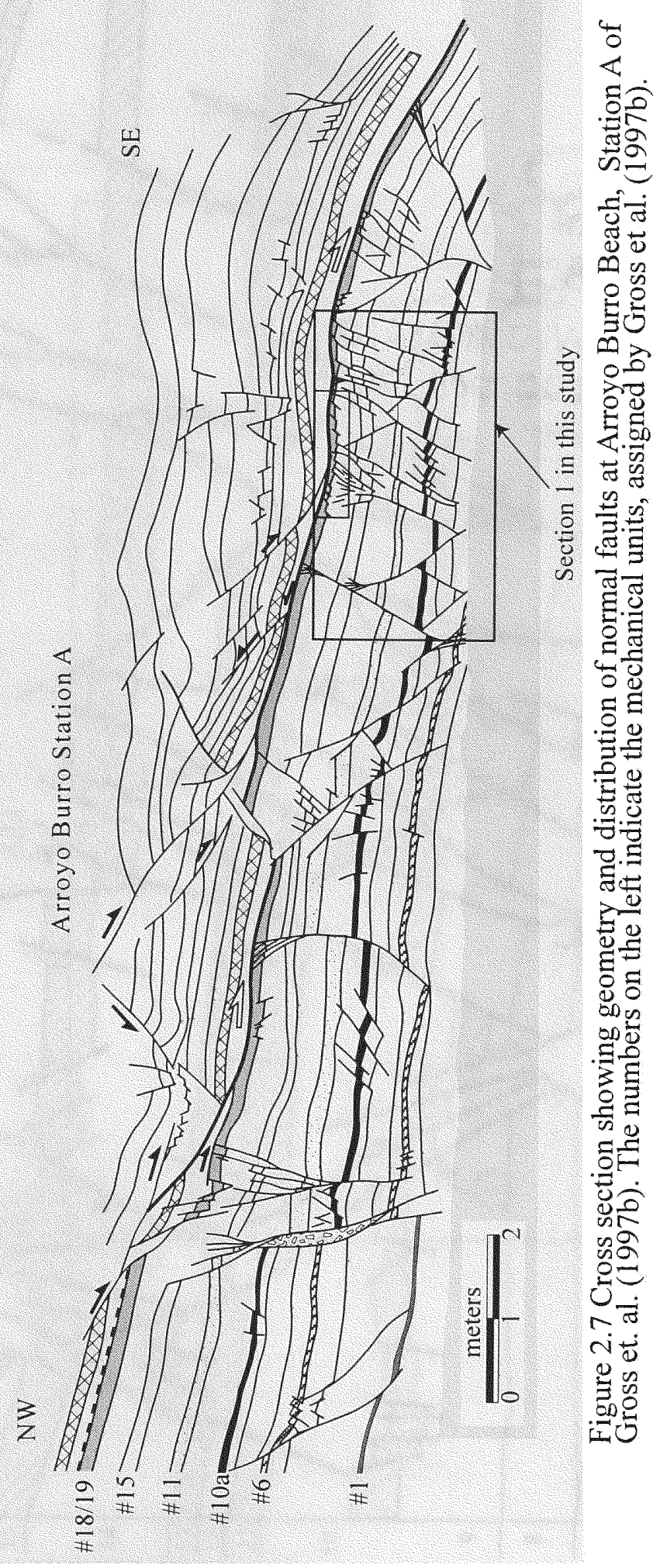




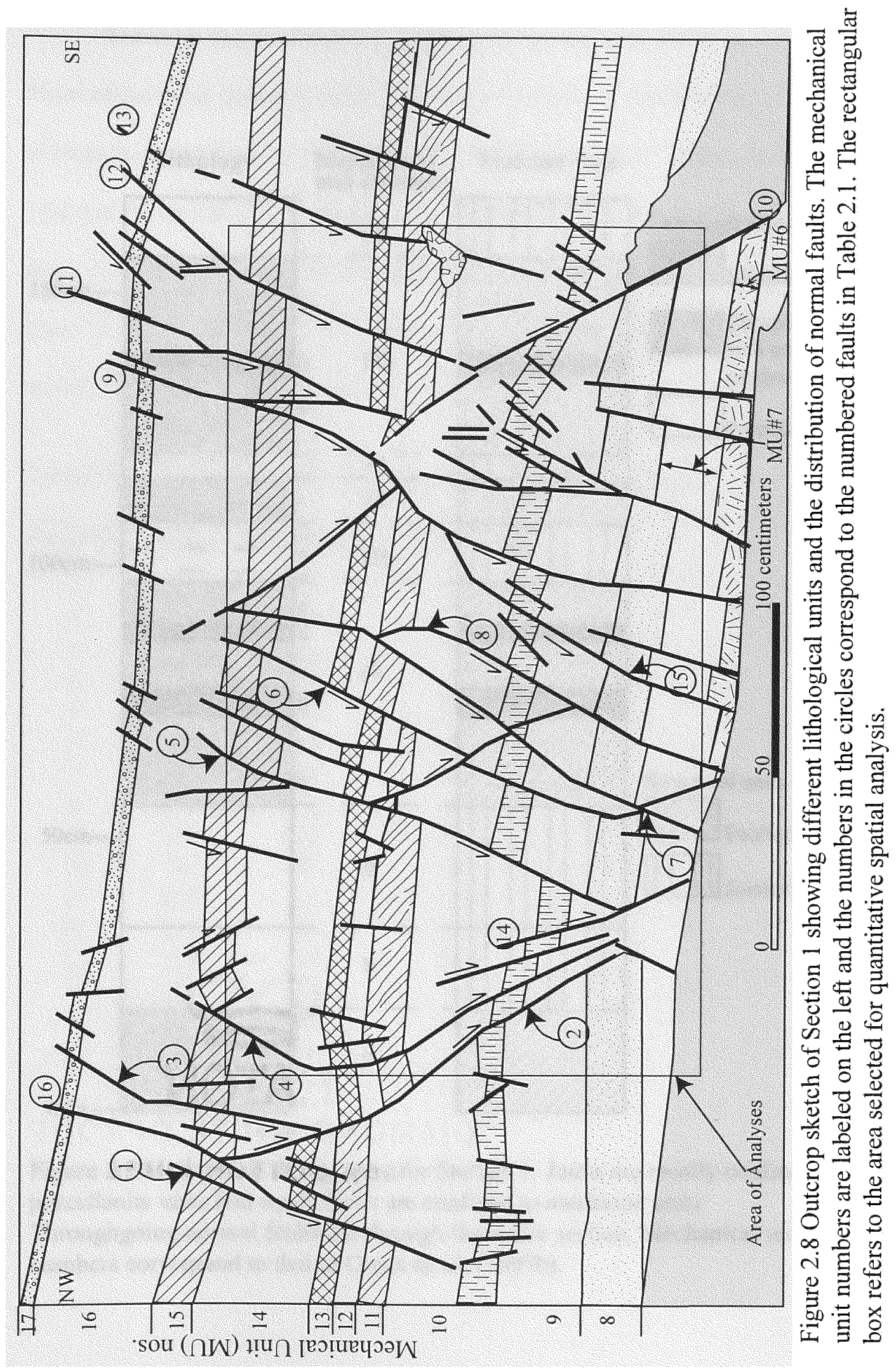




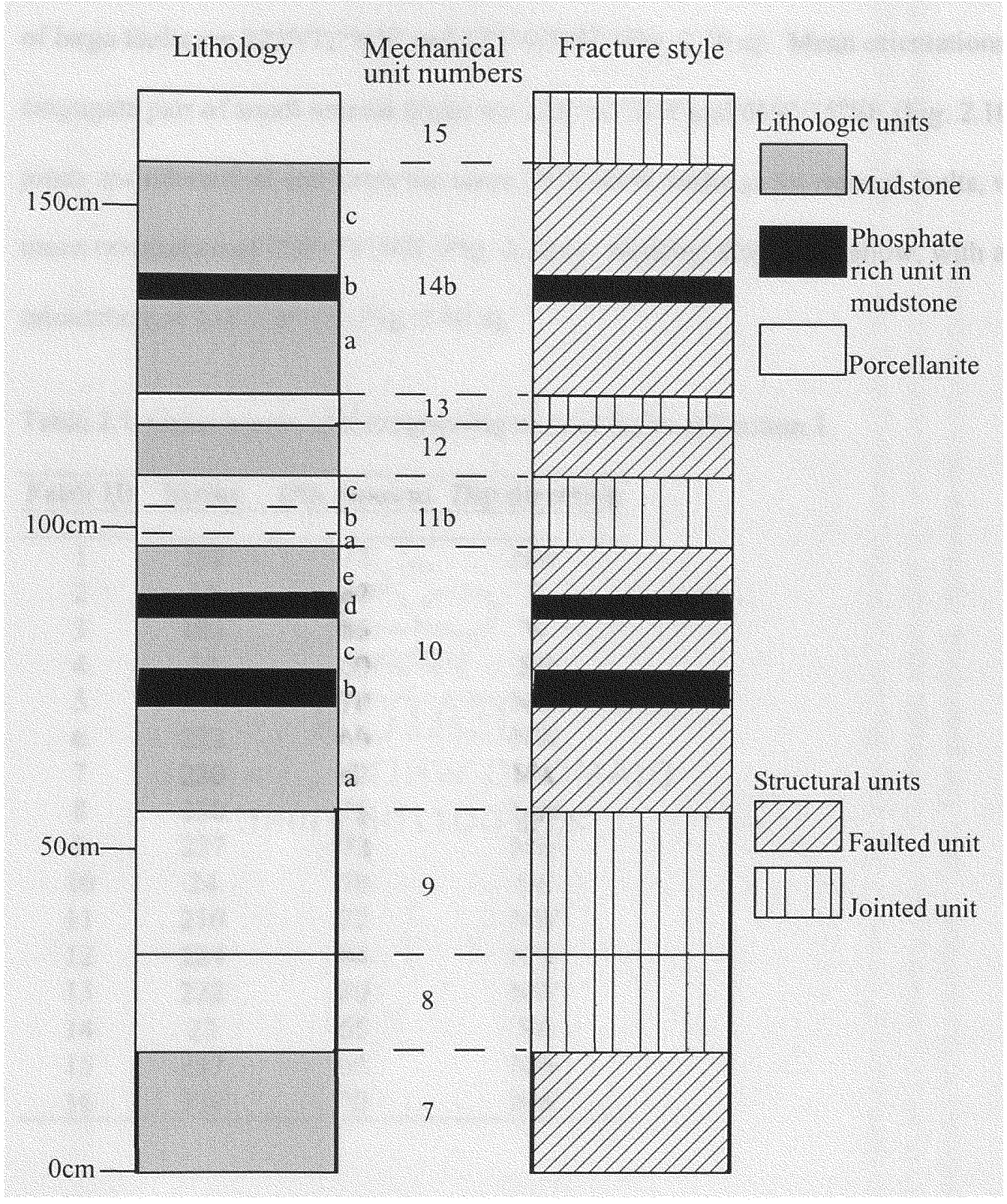

Figure 2.9 Mechanical stratigraphy for Section 1. Joints are mostly confined to porcellanite units and small faults are confined to mudstone units. Throughgoing normal faults cut through the entire section. Mechanical unit numbers correspond to that of Gross et. al. (1997b). 
The large and small normal faults appear as similarly oriented conjugate pairs. Mean orientations (listed as strike direction / dip amount / dip direction) for the two sets of large faults are $222^{\circ} / 71^{\circ} \mathrm{NW}$ and $025^{\circ} / 69^{\circ} \mathrm{SE}$ (Fig. 2.10 a). Mean orientations for the conjugate pair of small normal faults are $221^{\circ} / 63^{\circ} \mathrm{NW}$ and $019^{\circ} / 75^{\circ} \mathrm{SE}$ (Fig. $2.10 \mathrm{~b}$ ). The joints are subvertical and share the same NNE-SSW strike as the normal faults, with a mean orientation of $226^{\circ} / 71^{\circ} \mathrm{NW}$ (Fig. $2.10 \mathrm{c}$ ). Bedding dips are shallow, with a mean orientation of $335^{\circ} / 16^{\circ} \mathrm{NE}$ (Fig. $2.10 \mathrm{~d}$ ).

Table 2.1. Orientations of throughgoing normal faults of Section 1.

\begin{tabular}{cccc}
\hline Fault ID & Strike & Dip amount & Dip direction \\
\hline & & \multicolumn{3}{c}{} \\
\hline 1 & 212 & 72 & NW \\
2 & 18 & 82 & E \\
3 & 195 & 85 & W \\
4 & 39 & 60 & SE \\
5 & 220 & 70 & NW \\
6 & 222 & 60 & NW \\
7 & 230 & 62 & NW \\
8 & 230 & 75 & NW \\
9 & 237 & 72 & NW \\
10 & 24 & 70 & SE \\
11 & 210 & 72 & NW \\
12 & 224 & 84 & NW \\
13 & 222 & 80 & NW \\
14 & 22 & 65 & SE \\
15 & 237 & 65 & NW \\
16 & 230 & 70 & NW \\
\hline
\end{tabular}




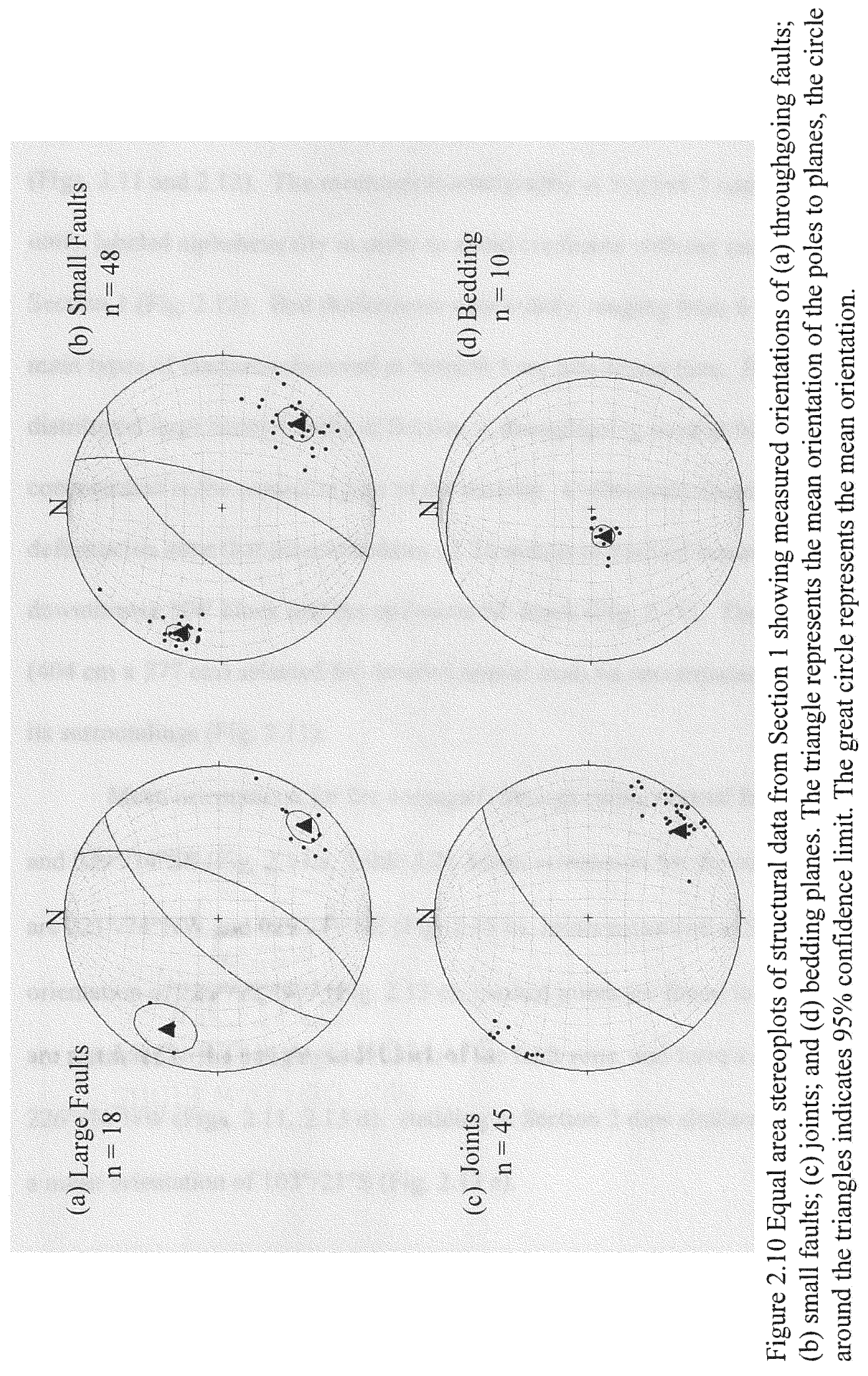




\subsubsection{Section 2}

The lithologic composition of Section 2 is primarily mudstone (calcareous, phosphatic and siliceous) with only one porcellanite unit near the base of the section (Figs. 2.11 and 2.12). The mechanical stratigraphy at Section 2 consists of nine main units, labeled alphabetically in order to avoid confusion with the numbered units at Section 1 (Fig. 2.12). Bed thicknesses vary widely, ranging from 6 to $95 \mathrm{~cm}$. The three main types of fractures observed at Section 1 are also found here. However, unlike the distributed large normal faults in Section 1, throughgoing normal faults in Section 2 are concentrated in the central region of the outcrop. Collectively these faults represent a deformation zone that accommodates $\sim 1.25$ meters of vertical separation between the downthrown NW block and the upthrown SE block (Fig. 2.11). The rectangular area $(404 \mathrm{~cm} \times 377 \mathrm{~cm})$ selected for detailed spatial analysis encompasses the fault zone and its surroundings (Fig. 2.11).

Mean orientations for the conjugate through-going normal faults are $223^{\circ} / 66^{\circ} \mathrm{NW}$ and $029^{\circ} / 74^{\circ} \mathrm{SE}$ (Fig. 2.13 a, Table 2.2). Mean orientation for the conjugate small faults are $221^{\circ} / 74^{\circ} \mathrm{NW}$ and $029^{\circ} / 71^{\circ} \mathrm{SE}$ (Fig. 2.13 b). Joints measured at Section 2 have a mean orientation of $228^{\circ} / 72^{\circ} \mathrm{NW}$ (Fig. $2.13 \mathrm{c}$ ). Faulted joints are found locally in unit D. They are restricted to the hangingwall block of the fault zone, and have a mean orientation of $226^{\circ} / 74^{\circ} \mathrm{NW}$ (Figs. $2.11,2.13 \mathrm{~d}$ ). Bedding at Section 2 dips shallowly to the south, with a mean orientation of $103^{\circ} / 21^{\circ} \mathrm{S}$ (Fig. $2.13 \mathrm{e}$ ). 


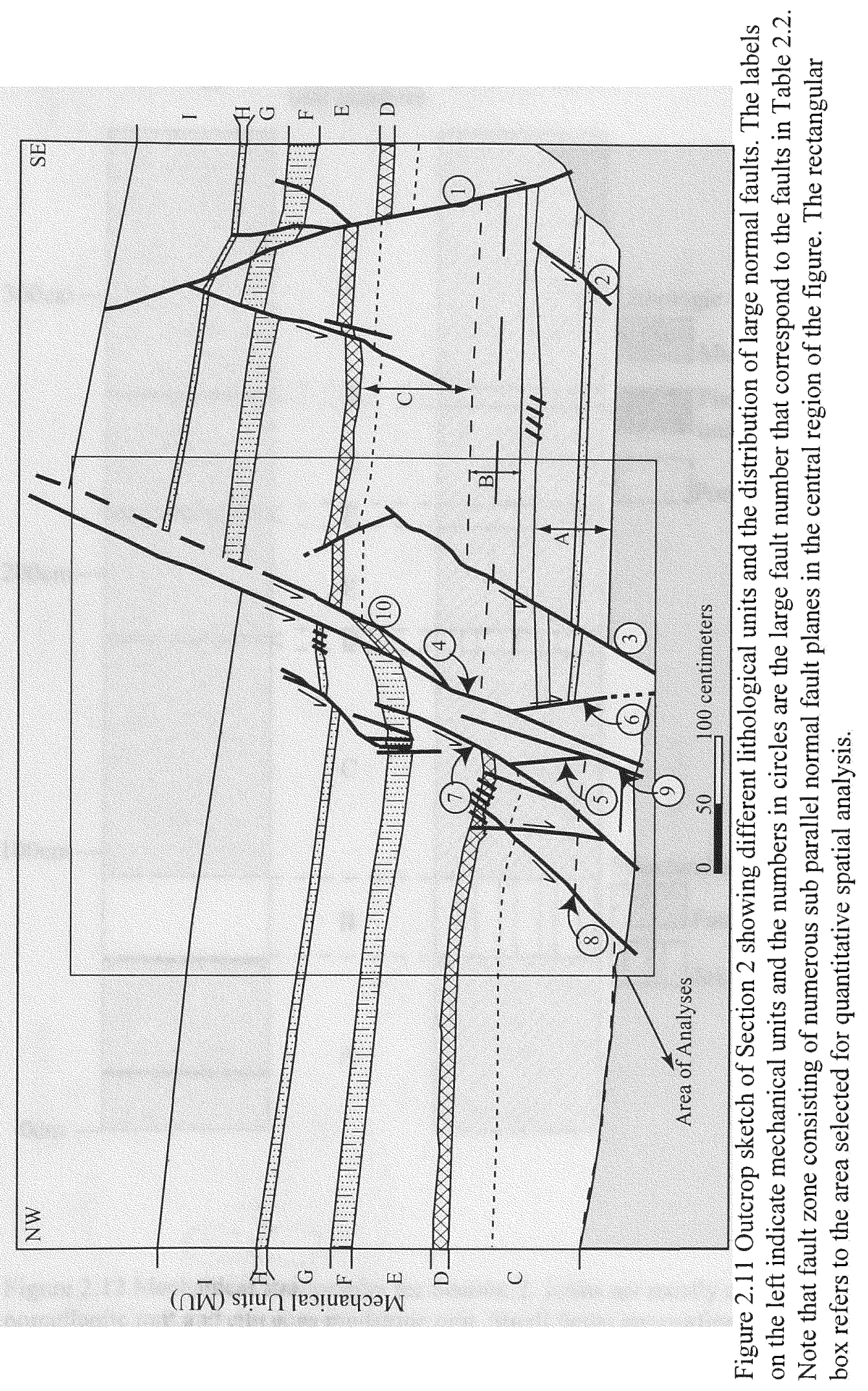




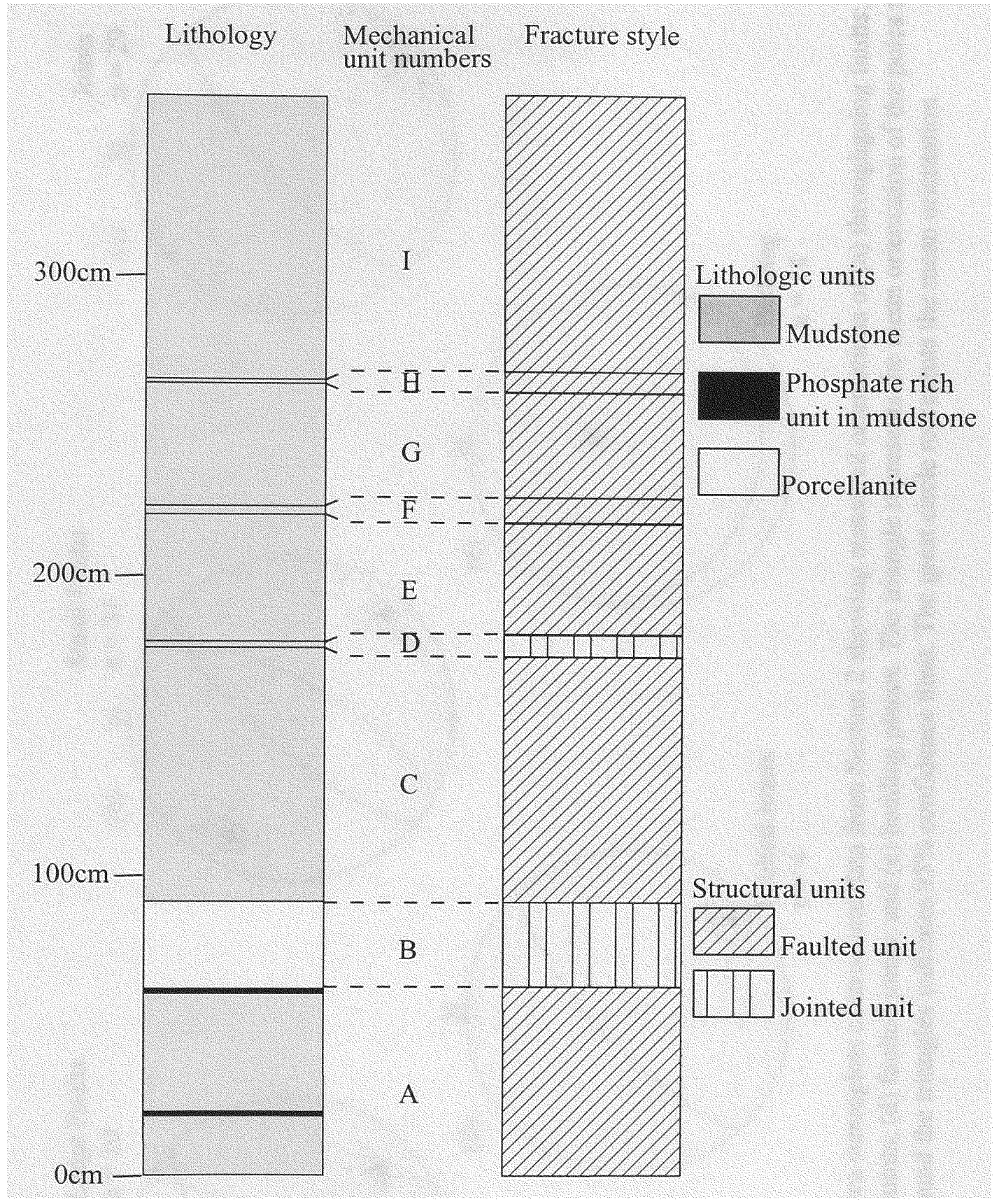

Figure 2.12 Mechanical stratigraphy for Section 2. Joints are mostly confined to porcellanite unit and siliceous mudstone unit. Small faults are confined to mudstone units, while throughgoing normal faults cut through the entire section. 


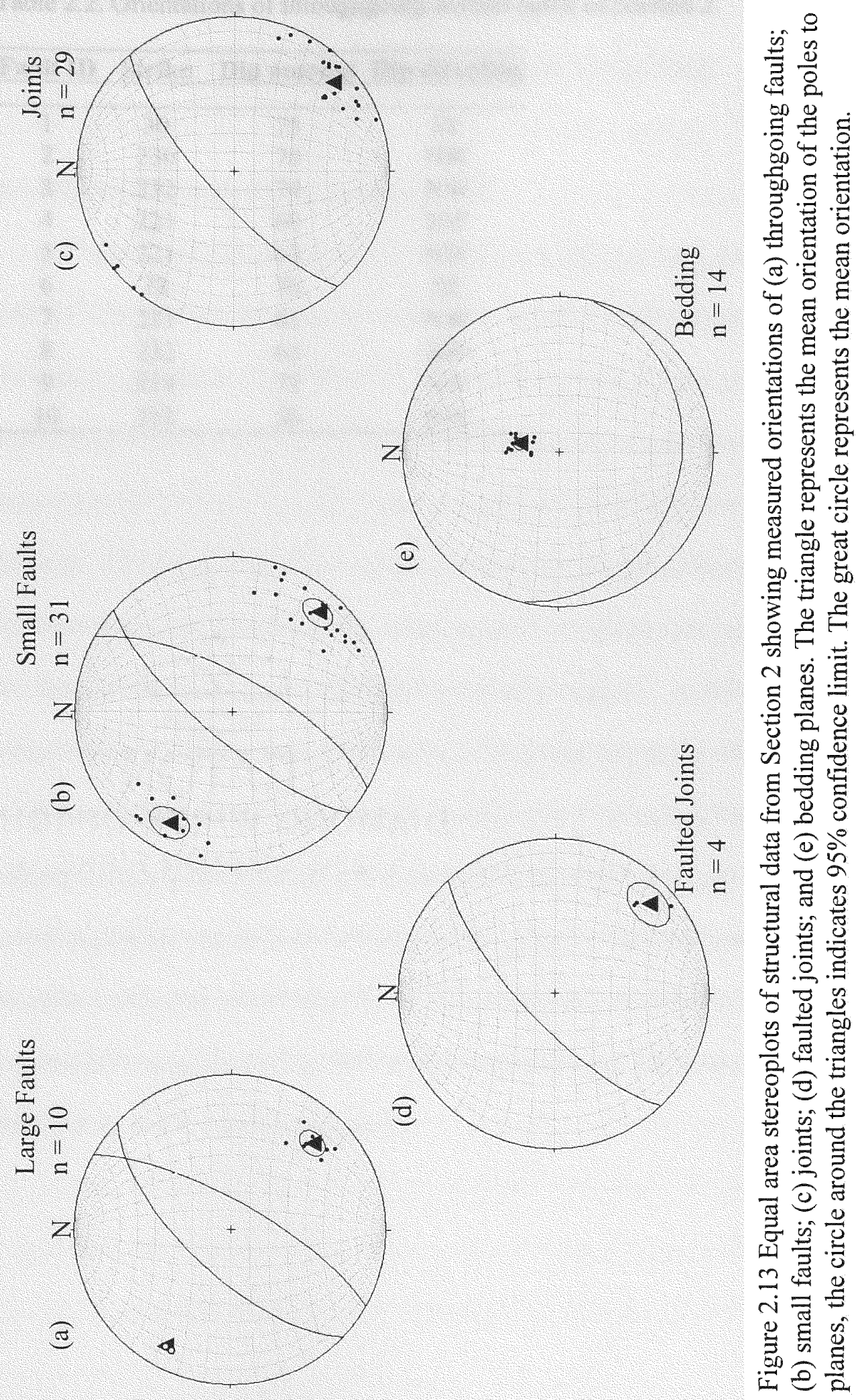


Table 2.2. Orientations of throughgoing normal faults of Section 2.

\begin{tabular}{cccc}
\hline Fault ID & Strike & Dip amount & Dip direction \\
\hline & & \multicolumn{2}{c}{. } \\
\hline 1 & 30 & 75 & SE \\
2 & 230 & 70 & NW \\
3 & 232 & 74 & NW \\
4 & 221 & 69 & NW \\
5 & 221 & 63 & NW \\
6 & 28 & 76 & SE \\
7 & 221 & 61 & NW \\
8 & 232 & 63 & NW \\
9 & 214 & 73 & NW \\
10 & 212 & 56 & NW \\
\hline
\end{tabular}




\section{CHAPTER 3}

\section{METHODS OF SPATIAL ANALYSIS}

\subsection{GIS and remote sensing packages used}

Spatial analyses were performed using the ESRI software, Arc View $3.2^{\circledR}$ and Arc GIS $8.1^{\circledR}$ (including Arc tools, Arc editor and Arc Info). ERDAS imagine $8.6^{\circledR}$ was used for image rectification. Specifically, three capabilities of GIS have proved extremely useful in evaluating fracture networks. One is the ability to generate maps comprised of numerous cells, with each cell having an assigned or calculated value of a fracture attribute. These maps constitute models that quantify the spatial distribution of an attribute, such as fracture intensity. Thus, regions of high fracture intensity (as well as low fracture intensity) can be identified and further analyzed. Overlay analysis, the comparison of different maps generated over the same region, is a second powerful tool of GIS well suited for fracture analysis. In this manner different factors that may influence fracture development can be compared, providing a quantitative method to establish possible correlations between fracture intensity and proximity to fault zones, for example. Lastly, the capabilities of Arc View extensions to identify fracture intersection and termination points have proved to be remarkably helpful in evaluating the structural connectivity of the fracture systems. 


\subsection{Transfer of field data to digital format}

The first step in the spatial analysis process is to transfer photographs and fracture sketches into digital format to produce a base map within the GIS. This is accomplished by taking careful field measurements and then applying image analysis to these data with remote sensing software. Once the photographs and sketches are rectified, they are imported into the GIS for spatial analysis.

Upon returning to the laboratory the photographs and fracture sketches are scanned and uploaded into ERDAS imagine version 8.6. The scanned images are then rectified by referencing the coordinates of the control points set at the outcrop (Fig. 2.5). Rectification refers to the process used to remove distortion and to calibrate photographic units to real-world distances (ERDAS, 2001). The software builds a transformation equation that relates the control point coordinates to the coordinates of the scanned image, and then applies that equation to the entire raster image. In this study a second order polynomial transformation is applied to the whole image. Initially a first order polynomial transformation was considered, which yielded an average RMS error of 1.9, with a maximum error of 4.2 at control point number 5 (Table 3.1). Then I excluded the control point number 5, which reduced the average RMS error to 1.6 and the maximum error of 3.8 at control point number 7. Next to improve the results of RMS error a second order polynomial transformation was performed that reduced the average RMS error to 0.4 , with a maximum RMS error of 0.9 at control point number 6 (Table 3.2). The "nearest neighbor" resampling method is used during rectification. The rectified image is then imported into the GIS software. Distances between control points and dimensions of 
structural features measured in the field are compared to the same features measured directly in the GIS in order to verify the accuracy of rectification.

The distortion-free sketches (Fig. 2.6) are digitized in the GIS software in order to generate a base map for spatial analysis. The digitization was done off the field sketch to make certain that the digitized sketch bears one-to-one correspondence with the structural interpretation made in the field. Digitizing off the field sketch rather than the photograph ensures the proper detection of each fracture.

Table 3.1 Table showing Root Mean Square (RMS) error for the first order polynomial transformation of Section 1 outcrop photograph.

\begin{tabular}{cc}
\hline Control point & RMS Error \\
\hline 1 & \\
\hline 2 & 0.263 \\
3 & 0.434 \\
4 & 0.828 \\
6 & 0.916 \\
7 & 2.603 \\
8 & 3.845 \\
9 & 2.879 \\
10 & 1.276 \\
\hline
\end{tabular}

Table 3.2 Table showing Root Mean Square (RMS) error for the second order polynomial transformation of Section 1 outcrop photograph.

\section{Control point RMS Error}

\begin{tabular}{cc}
\hline 1 & 0.084 \\
2 & 0.064 \\
3 & 0.72 \\
4 & 0.675 \\
6 & 0.893 \\
7 & 0.775 \\
8 & 0.152 \\
9 & 0.222 \\
10 & 0.426 \\
\hline
\end{tabular}


The rectified fracture sketches are displayed on the computer monitor, and linear features such as joints, faults and bedding contacts are traced using a mouse (Fig. 3.1). The output is a digital data set that is spatially referenced to the source document (i.e., the rectified sketch and photograph). Different geologic features (e.g., joints, faults and bedding) are classified into separate data categories, so that they can be analyzed both individually and in combination with other features.

Two main types of spatial analyses were performed based on data structure format, vector analyses and raster analyses. Vector data consist of points, lines, arcs and polygons that represent objects defined by sets of vertices. A raster data structure is a series of rows and columns that form a regular grid pattern. Each cell within this matrix is identified by its coordinate position and an attribute (or a calculated value). The following sections describe the specific methods used to analyze the fractures within the GIS.

\subsection{Vector based analysis}

Fractures and stratigraphic units are stored in the GIS database in vector data format. Fracture traces and stratigraphic contacts are represented by arcs, stratigraphic layers by polygons and fracture terminations are represented by points. The following analyses were performed on these vector data:

\subsubsection{Fracture length}

Fracture length is measured in Arc View as traces exposed on the outcrop surface. In Arc View, after digitizing the fracture maps, the length of all the features are updated 
automatically by using the "xtools" extension available with the Arc View GIS package. Fracture length is a parameter that characterizes fracture size.

\subsubsection{Fracture Spacing}

Fracture spacing is calculated using the GIS software in a manner similar to the methods employed in field. In the field, traverses are taken perpendicular to the average orientation of the fracture set, and the distance between two consecutive joints intersecting the line of traverse is defined as the fracture spacing. In the GIS software, scanlines are drawn approximately perpendicular to the fracture traces (Fig. 3.2). The scanline is split at the intersection of the fracture traces, thus the length of each segment of the split-scanline represents the fracture spacing for the adjacent pair of fractures. This is an automated process done by the "point and line" extension downloaded from ESRI website. The length of the split segment is updated using "xtools" extension to get the fracture spacing measurements between adjacent pairs of fractures. The software enables the precise positioning of the scanlines with respect to the upper and lower boundaries of the bed. Where beds are displaced by throughgoing faults the scanlines are shifted to maintain the same stratigraphic position within the bed. In order to ensure representative fracture spacing, three equally spaced scanlines are measured in each bed (Fig. 3.3).

The spacing data derived from each scanline is output as tabular data and exported to Microsoft Excel. The population statistics (maximum, minimum, mean, median, standard deviation, sum and coefficient of variation) of spacing data from scanlines in each bed are calculated in Excel. 
Fracture spacing is an important parameter that characterizes the distribution of joints and faults along a line. It is a standard method used to quantify fracture (onedimensional) distribution. The spacing statistics provide important information regarding fracture clustering.

\subsubsection{Fractal Dimension}

The term "Fractal" was coined by Benoit Mandelbrot (1982) to describe objects that were too irregular to be described by Euclidean geometry. Fractal geometry is a branch of mathematics that can identify and quantify how the geometry of patterns repeats from one size to another (Barton, 1995). As opposed to classical geometry that deals with objects of integer dimension, fractal geometry describes non-integer dimensions. For example in three dimensional space the topological dimension of a straight line is 1 and a flat plane is 2 , whereas the fractal dimension of a curved line is between 1 and 2, and that of an irregular plane is between 2 and 3. The fractal dimension D of an object can be defined by the relationship (Mandelbrot, 1967; Voss, 1988):

$$
\begin{aligned}
& N=1 / r^{D} \\
& \text { Or, } \\
& D=\log N / \log (1 / r)
\end{aligned}
$$

where $\mathrm{r}$ is the linear scaling and $\mathrm{N}$ is the resulting increase in size.

The fractal dimension of an object varies between its Euclidean dimension and its Euclidean dimension plus one. Thus the fractal dimension of fractures, represented by lines, varies between 1 and 2 . The fractal dimension of a fracture distribution is an indicator of homogeneity, complexity and connectivity of fracture network. 
The fractal dimension for a $2 \mathrm{D}$ fracture network may be calculated using the box counting method (Fig. 3.4) (Mandelbrot, 1983; Feder, 1988). In this method, a grid of cells (or box) is laid over the fracture map and the numbers of cells (N) intersecting one or more fractures are counted. This procedure is repeated for a large number of cell sizes (r). The $N$ and $1 / \mathrm{r}$ values are plotted on $\log$-log axes and the slope of the best fit line gives the fractal dimension for the fracture network. To obtain a more rigorous result, small increments between the cell sizes are used (Pruess, 1995).

Using the Arc View "Edit tools" extension, several grids of various cell sizes (r) are drawn to cover all of the fractures in the study area. The cell sizes are chosen according to the fracture size and the dimensions of the study area. The smallest cell size is greater than the length of the smallest fracture, whereas the largest cell size is less than the size for which all the cells are intersected by the fractures. The cells intersecting with one or more fractures are highlighted (Fig. 3.5) by setting a logical query in Arc View and the number of cells $(\mathrm{N})$ intersected by fractures for each grid size is noted from the attribute table of the grid. Then $\mathrm{N}$ versus $1 / \mathrm{r}$ is plotted on a logarithmic scale. The slope of the best fit line through the data points gave the fractal dimension of the respective fracture distribution.

\subsubsection{Fracture Connectivity}

In a fracture network, a group of linked fractures is known as a "cluster" (Stauffer, 1985), a term borrowed from the concepts of percolation theory (Chelidze, 1986;

Bebbington et al., 1990; Berkowitz and Balberg, 1993; Berkowitz, 1995; and Gueguen, et al., 1997). The cluster size of any fracture network is defined as the proportion of the 
total fracture trace length in the study area belonging to the largest cluster (Odling, 1997). Thus:

Cluster size $=\sum$ Fracture trace length in the largest cluster_(cluster length). $\sum$ Fracture trace length in the study area

Fractures in the percolating cluster, which are devoid of any dead-end fracture segments (Fig. 3.6), constitute the "fracture backbone" (Priest, 1993) that connects the opposite sides of the study area (Fig. 3.7).

GIS software can identify clusters and the backbone within fracture networks. In the first step, the intersection nodes of fractures are converted to points using the Arc View "point and line" function, then the fractures that contain an intersection node are separated from the network by making a logical query. These fractures constitute the fracture clusters (Fig. 3.8). Next, the termination points of the fractures belonging to the clusters are converted to points. In the following step, termination points within fracture clusters are selected by making a logical query and these fracture segments are deleted to generate a fracture cluster without any dead-end fracture segments. Finally, any fracture cluster that intersects the two opposite sides of the study area is identified. This is the backbone of the fracture network that establishes a continuous pathway for fluid flow. The permeability of a fracture backbone depends on the connectivity of the fracture network. Thus it is very important to identify the backbone of the fracture system because it facilitates flow through the fracture network. 


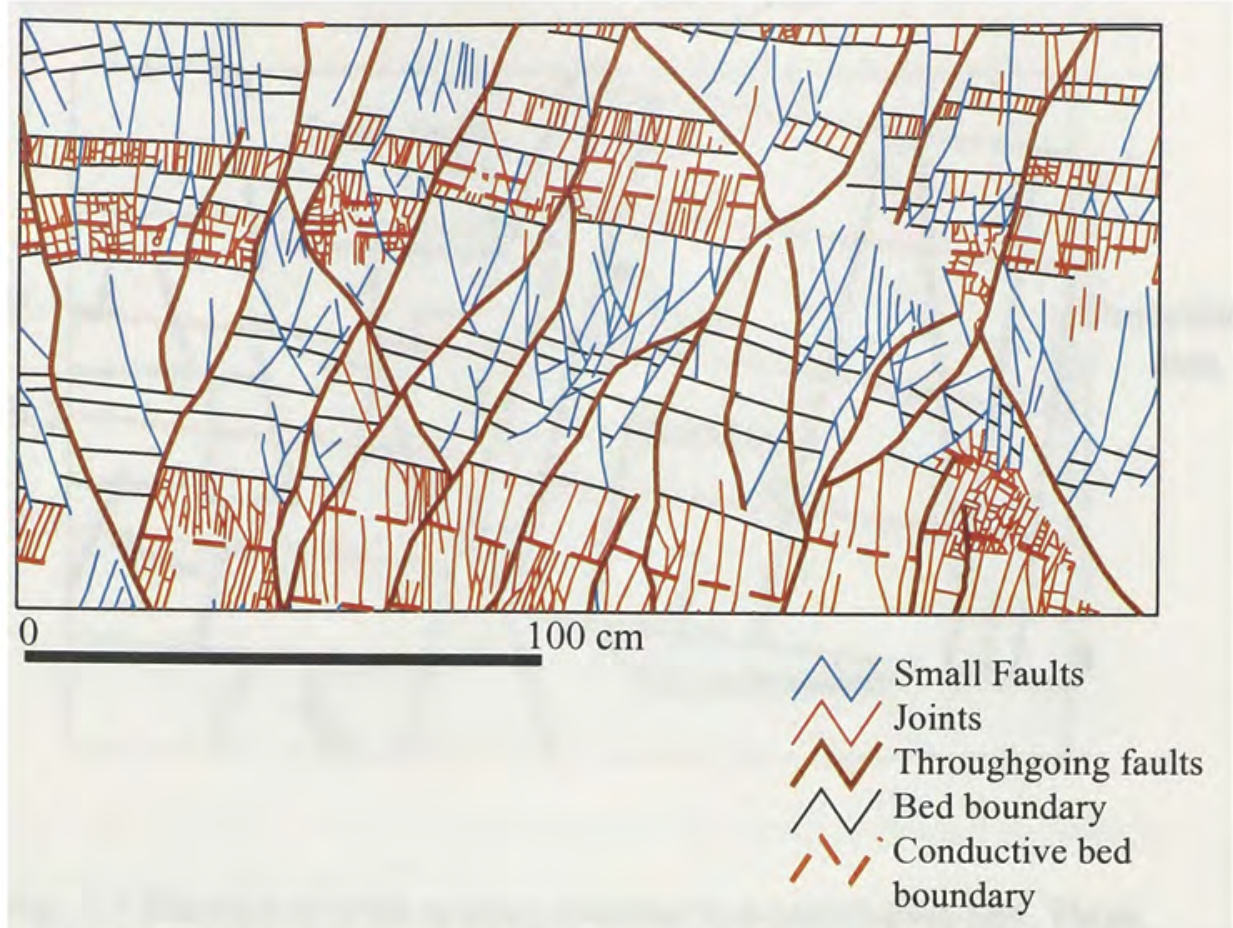

Fig. 3.1 Digitized sketch of rectified fracture map shown in Figure 2.5 and Figure 2.6.

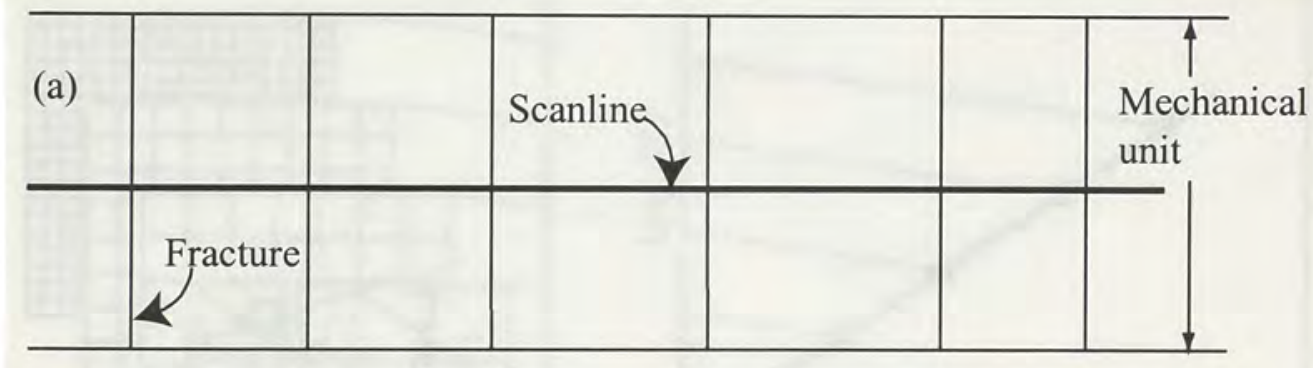

(b)

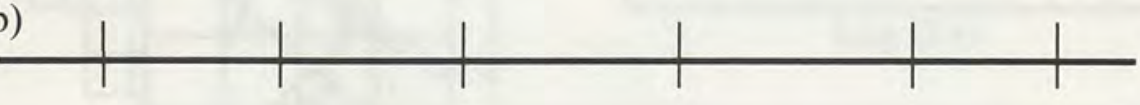

(c)

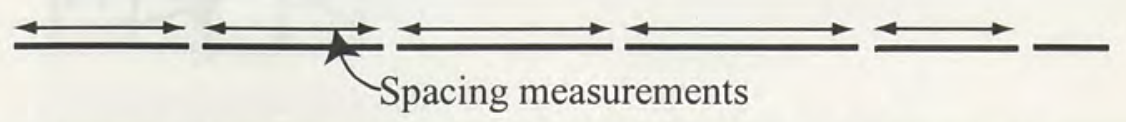

Fig. 3.2 Schematic diagram illustrating the scanline method of measuring fracture spacing. (a) Placement of scanline (b) Cutting of scanline at intersection points. (c) Calculation of spacing values along scanline. 


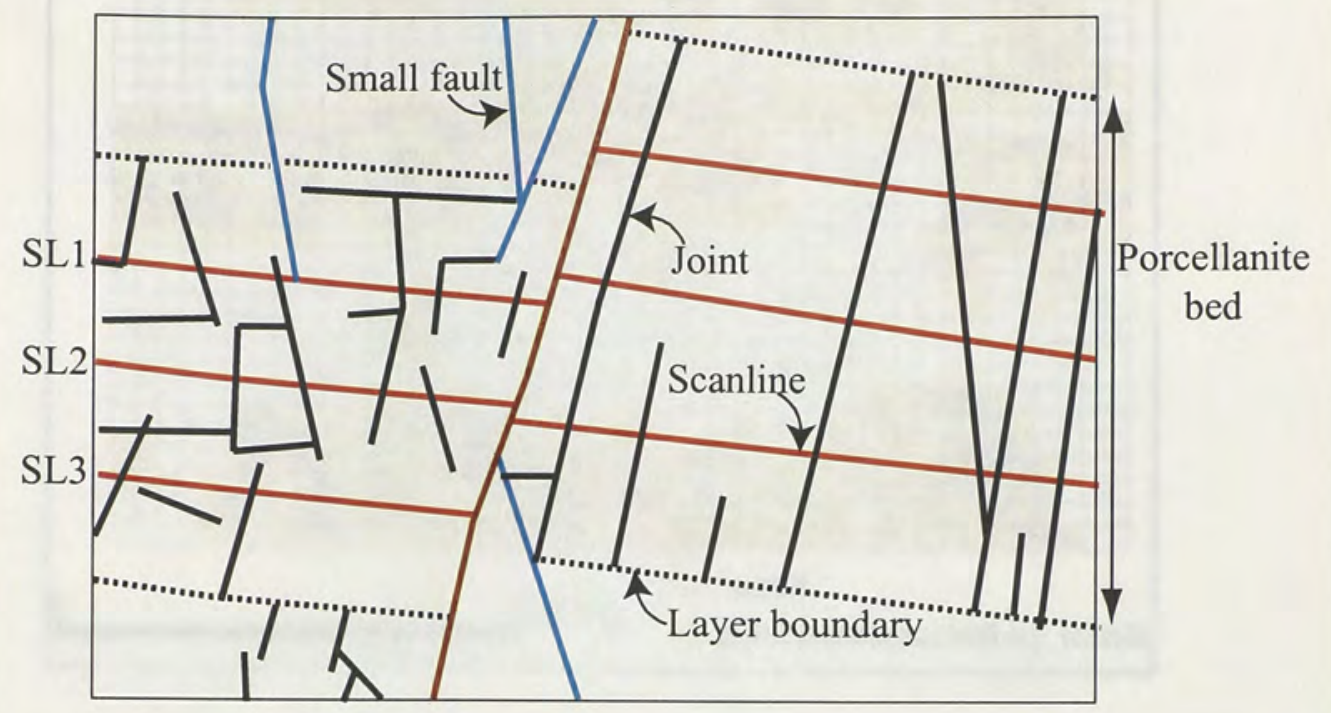

Fig. 3.3 Example of joint spacing scanline in a porcellanite bed. Three equally spaced, parallel scanlines are measured in each bed. Scanline numbers correspond to that of Table 4.1 and 4.2.

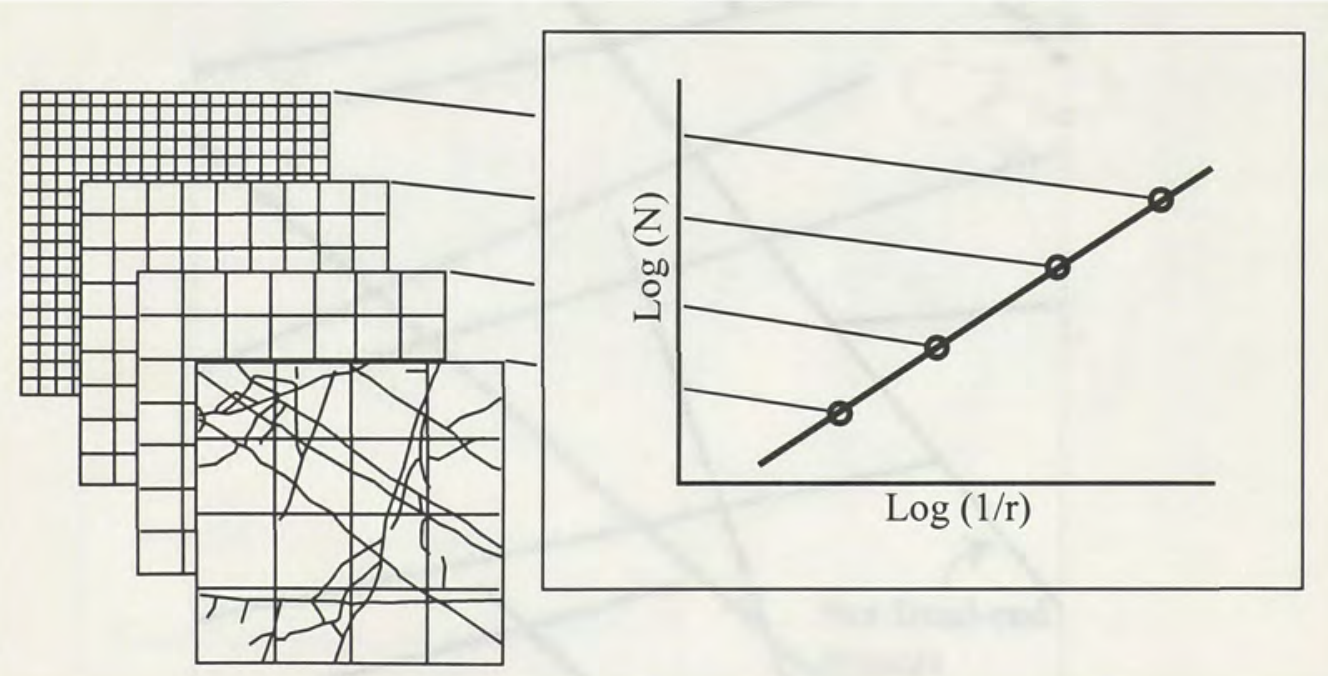

Fig. 3.4 Illustration of method used for calculating fractal dimension (Barton, 1995). $\mathrm{N}=$ Number of cells or boxes intersected by fractures, $\mathrm{r}=$ cell or box size. 


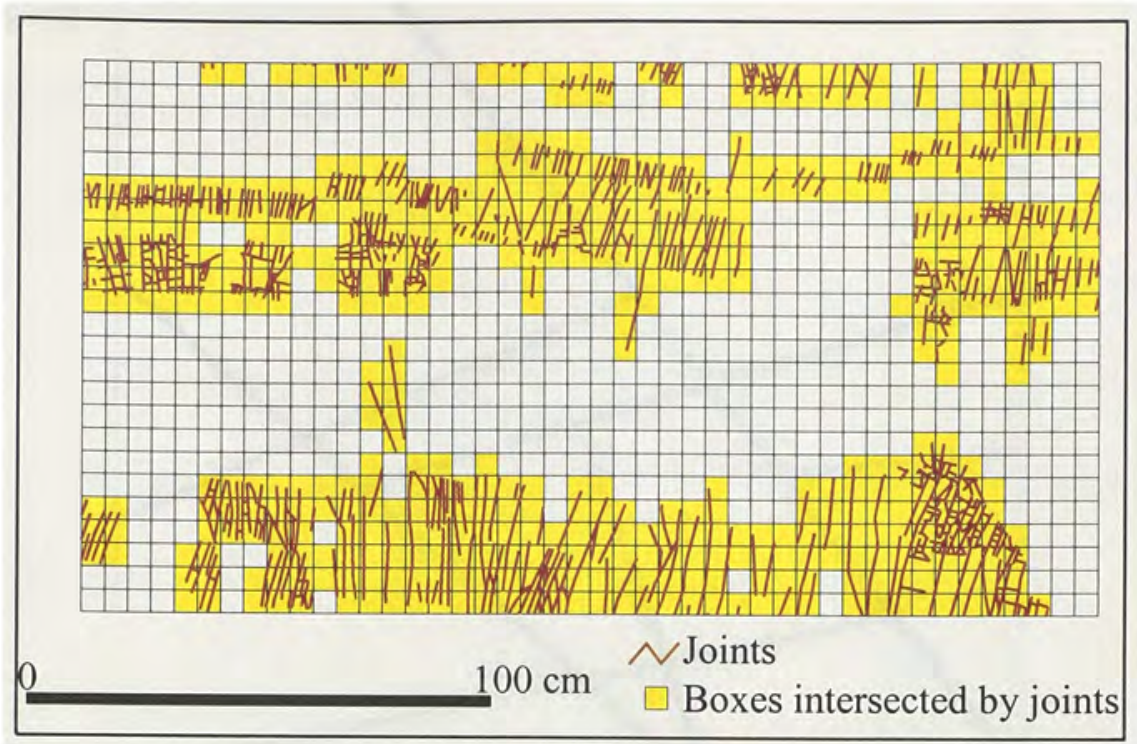

Fig. 3.5 Grid of $5 \mathrm{~cm}$ cell size overlaid on the fracture map to determine the fractal dimension of joints.

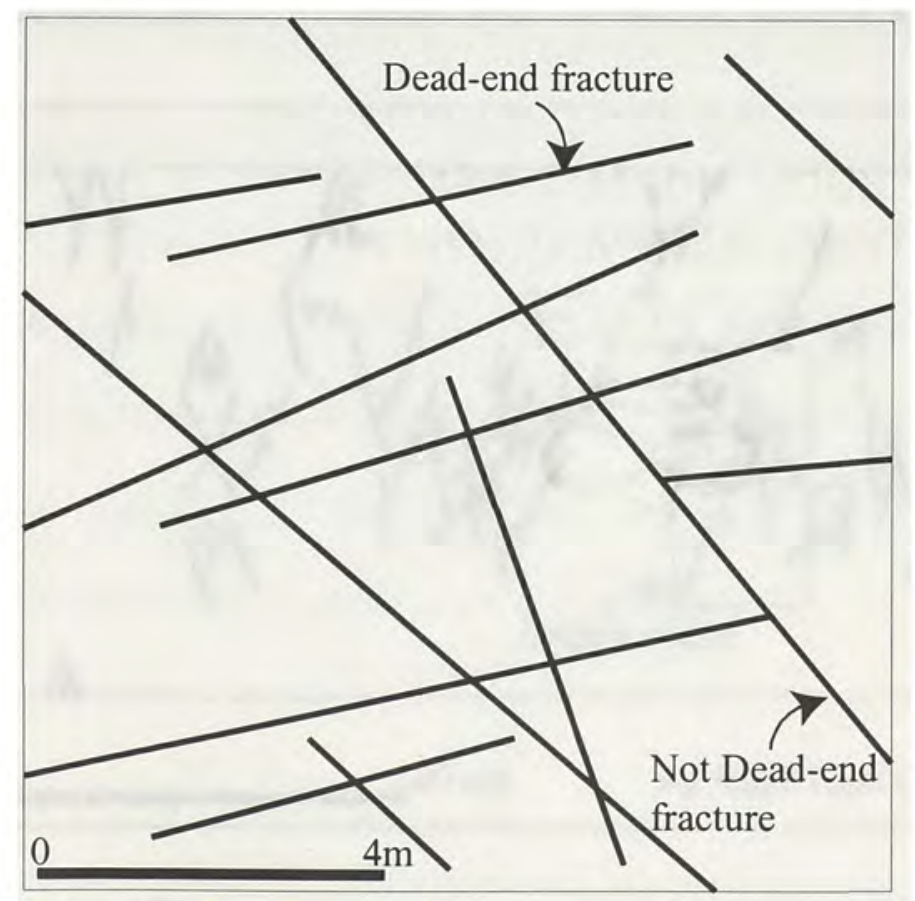

Fig. 3.6 Example of a fracture network with dead-end fracture segments and fracture segments belonging to the backbone (Priest, 1993). 


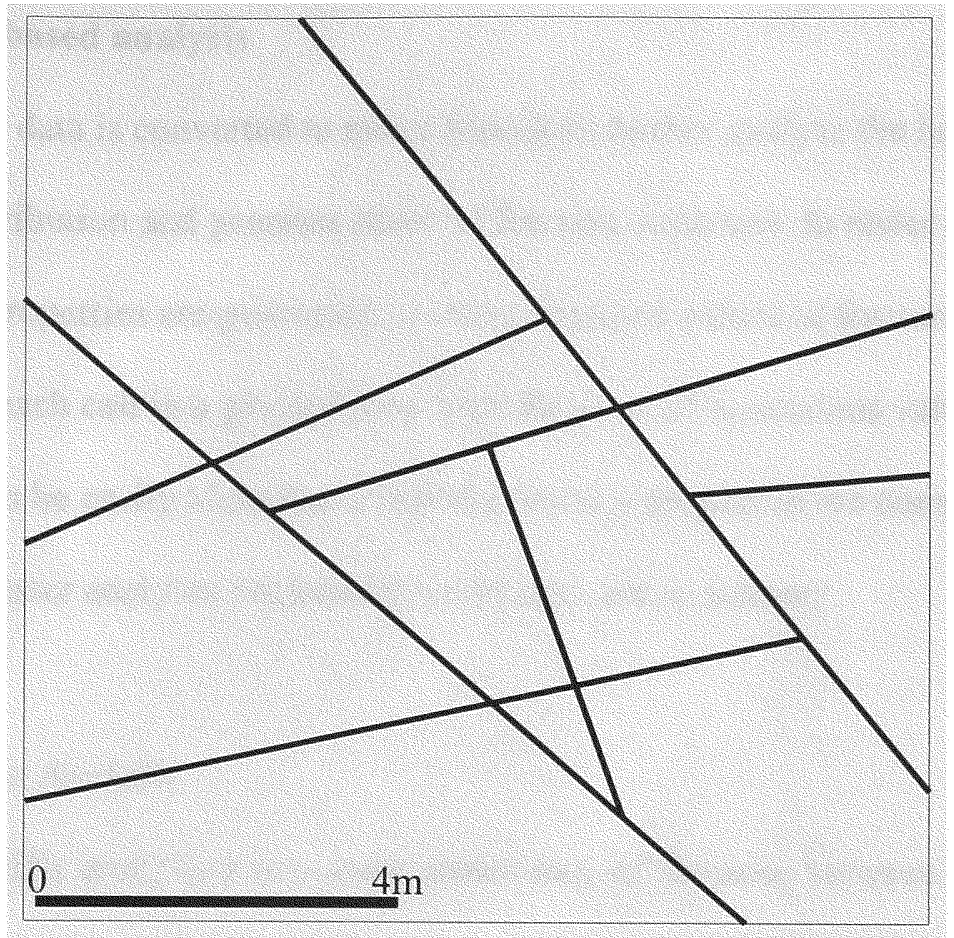

Fig. 3.7 Fracture backbone generated from the fracture network of Figure 3.8.

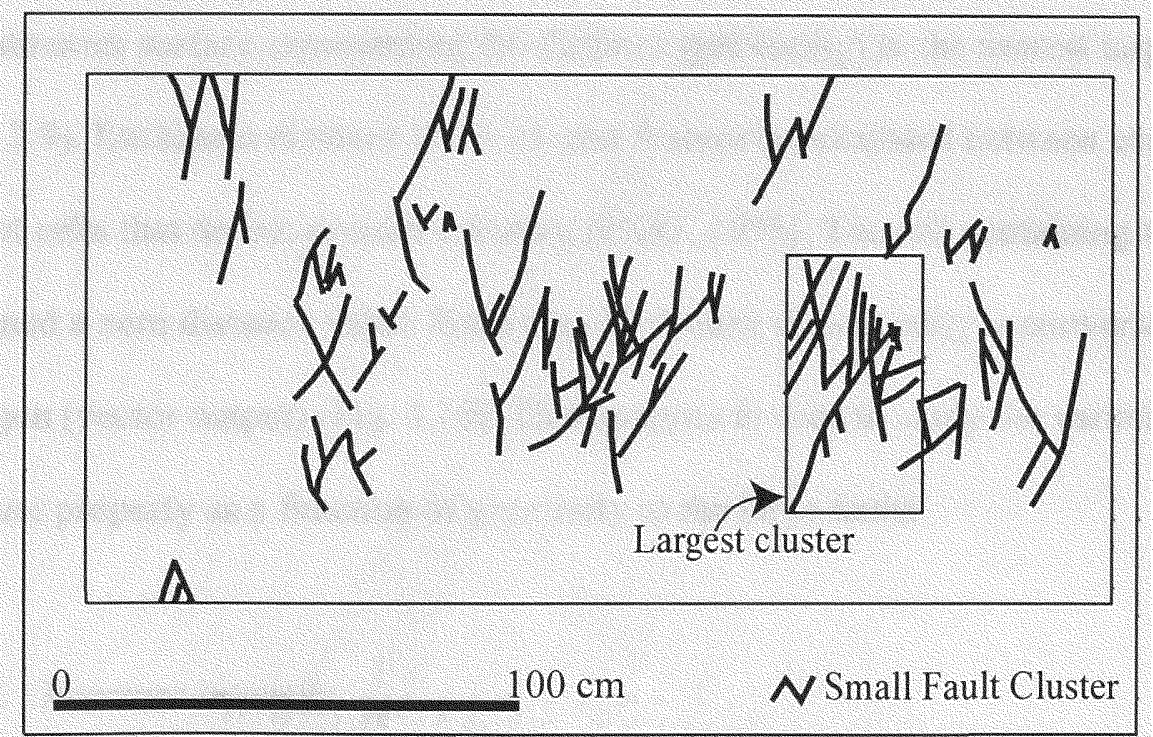

Fig. 3.8 Example of fracture clusters generated from a digitized fracture map. The cluster encompassed by the box is the largest cluster in the area. There is no fracture backbone in this example. 


\subsection{Raster based analysis}

Vector data is converted to raster format to further analyze the heterogeneity of the fracture distribution and generate maps of fracture attributes. In raster data format, maps of fracture properties are generated, where calculated values of fracture attributes are assigned to each cell in a gridded map area. Regions of anomalous values of fracture attributes can be easily identified when the fracture properties are compiled in contour maps. The raster analyses performed on the data are as follows:

\subsubsection{Buffer Analysis}

In buffer analysis a two-dimensional map of 'distance between fractures' is generated using the "Find Distance" function of the Arc View spatial analyst tools. The "find distance" utility in Arc View creates a distance contour for a feature. The output is a continuous surface representing the distance (proximity) to the nearest target feature (Fig. 3.9). Euclidean distance to the closest feature is calculated between each of the output cells that do not contain a feature (ESRI, 1996). The cell containing a feature is assigned a zero distance value. Each classified zone of proximity is converted to a polygon (vector output) (Fig. 3.10). This analysis is used to study the variation of a fracture property as a function of proximity to the large faults.

\subsubsection{Fracture intensity}

Fracture distribution in two-dimensional space is quantified by several methods. Renshaw (1997) defined spatial density of fractures as the summation of the half-length square of all the fractures divided by the study area containing the fractures. Mauldon et. 


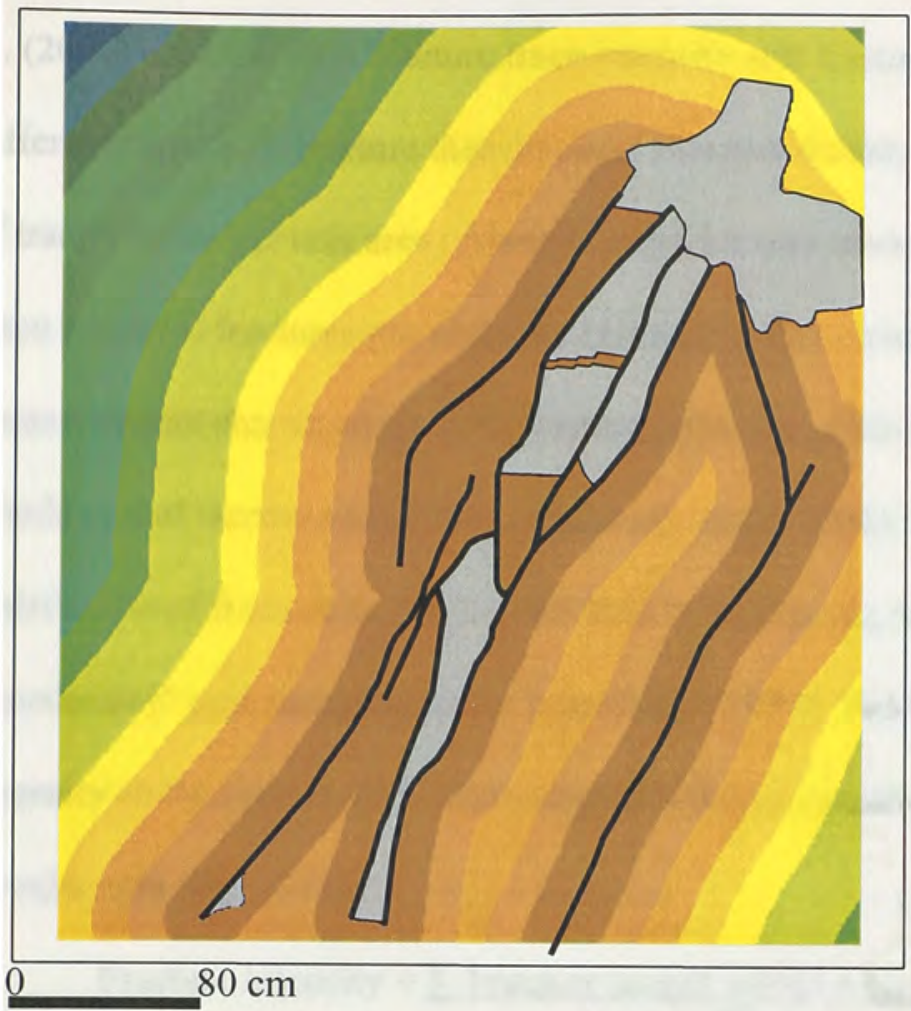

$\square$ Unmappable breccia and gouge NBig Fault Distance buffer around big faults $(\mathrm{cm})$

\begin{tabular}{|l|l|}
\hline & $0-15$ \\
\hline & $15-30$ \\
\hline & $30-45$ \\
\hline & $45-60$ \\
\hline & $60-75$ \\
\hline & $75-90$ \\
\hline & $90-105$ \\
$105-120$ \\
$120-135$ \\
$135-150$ \\
$150-165$ \\
$165-180$ \\
$180-195$ \\
$195-210$ \\
$210-225$ \\
$225-240$
\end{tabular}

Fig. 3.9 Distance buffer map of large faults.

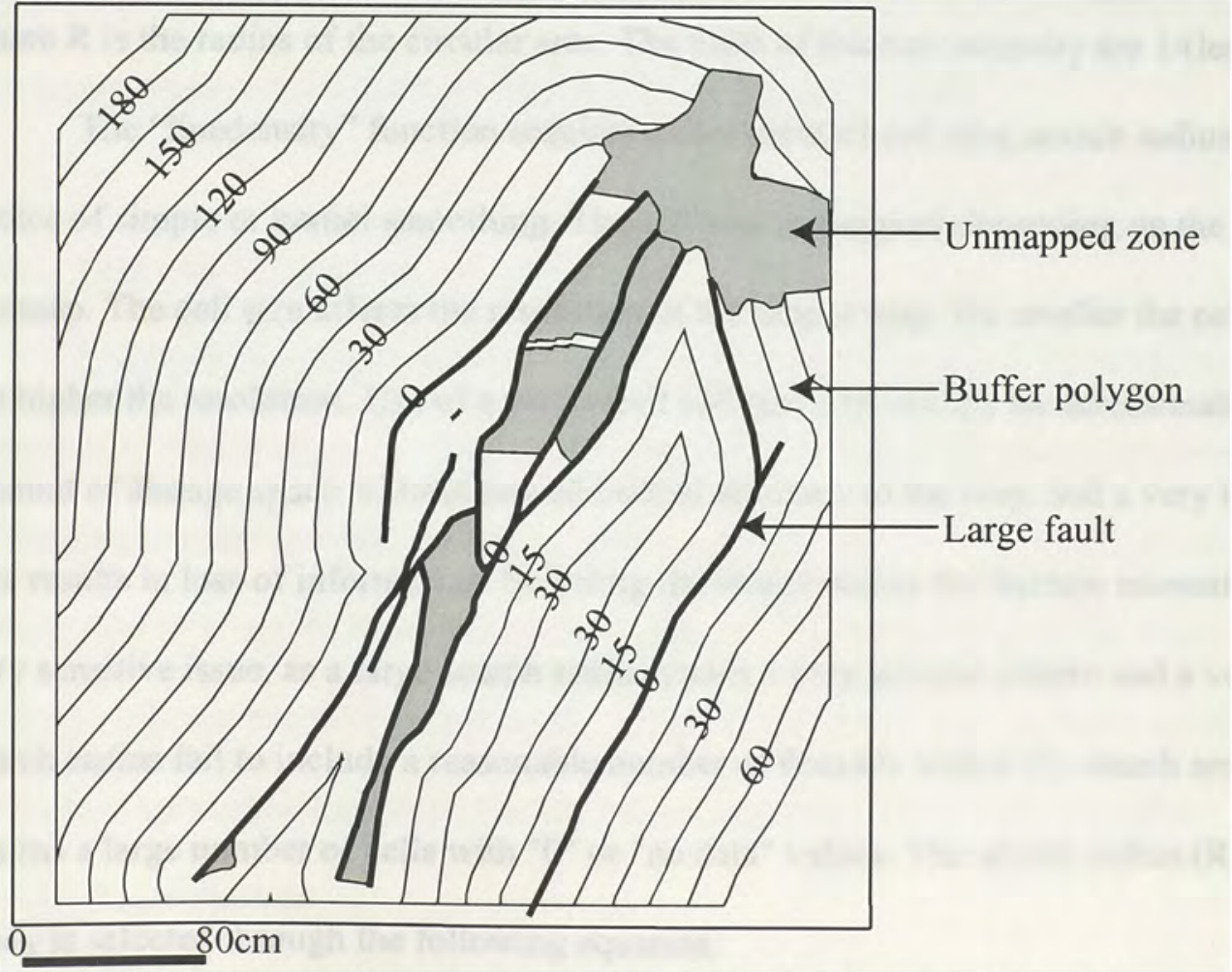

Fig. 3.10 Distance buffer polygons corresponding to the map of Fig. 3.9. 
al. (2001) used the term fracture trace intensity and fracture trace density to characterize different aspects of fracture distributions. Fracture density is defined as the mean number of trace centers per unit area $\left(1 /\right.$ length $\left.{ }^{2}\right)$ and fracture intensity is defined as the mean total trace length of fractures per unit area (1/length). Thus fracture trace intensity is a parameter that characterizes both fracture density and size (Dershowitz and Herda, 1992; Mauldon and Dershowitz, 2000; Rohrbaugh et al., 2002). In this study the spatial distribution of fracture traces is quantified by evaluating fracture intensity using the "linedensity" grid function in Arc Info (ESRI, 1997). The function calculates the fracture intensity as the sum of all fracture lengths within a specified search radius divided by the circular area (Fig. 3.11):

$$
\text { Fracture intensity }=\frac{\sum \text { Fracture length within a circular search area }}{\pi \mathrm{R}^{2}}
$$

where $\mathrm{R}$ is the radius of the circular area. The units of fracture intensity are $1 /$ (length).

The "linedensity" function requires a user input of cell size, search radius and a choice of simple or kernel smoothing. The cell size is assigned depending on the scale of the map. The cell size affects the resolution of the output map; the smaller the cell size the higher the resolution. Use of a very small cell size will occupy an unreasonable amount of storage space without any additional accuracy to the map, and a very large cell size results in loss of information. Selecting the search radius for fracture intensity is a very sensitive issue, as a large search radius yields a very general pattern and a very small search radius fail to include a reasonable number of features within the search area and returns a large number of cells with " 0 " or "no data" values. The search radius $(R)$ for this study is selected through the following equation: 


$$
\mathrm{R}=(\mathrm{A} / \mathrm{n})^{1 / 2}
$$

where $\mathrm{A}$ is the area of study and $\mathrm{n}$ is number of fractures occupying the study area.

Finally, the fracture intensity grid is generated by using the kernel smoothing option of interpolation. Output of the linedensity function is a grid theme with each cell assigned the calculated fracture intensity value (Figs. 3.12, 3.13, 3.14).

The fracture intensity map thus produced has been studied as a whole and also in classified segments. The summary statistics of fracture intensity values for the whole map are output in tabular format. The statistics along different beds are extracted using the 'summarize zones' utility of the spatial analyst functions in Arc View. The function computes the statistics from the cells (mean, sum, maximum, minimum and range) that fall within a cartographic zone defined by polygons (Fig. 3.15). This function is used to compare the fracture intensity statistics in different lithologic units as well as variations of fracture intensity as a function of proximity to the large faults.

\subsubsection{Map overlay analysis}

Using the Arc Info 'linedensity' routine, joint intensity and fault intensity maps are generated for the study area. A minimum threshold value is determined for the map and any cell values that are below the threshold are assigned a 'no data' value, so that they are not considered in any further steps of the analysis. Then the joint intensity map and the fault intensity are overlaid on one another to generate a third map. In the new map, the cell values are reclassified, such that the map is classified into 4 discrete values representing 4 classes:

a) Cells with joint intensities greater than the threshold value. 
b) Cells with fault intensities greater than the threshold value.

c) Cells with both joint and fault intensities greater than the threshold value.

d) Cells with both joint and fault intensities less than the threshold value.

For rock columns exhibiting fracture partitioning, the new map will show a larger area occupied by classes ' $a$ ' and ' $b$ ' compared to ' $c$ '. The result is expressed as percentage of total area covered by each of the four cell types.

\subsubsection{Dip separation map of faults}

Fault displacement magnitude is derivable when a linear feature (e.g. a bedding trace) intersecting the fault surface is displaced by the fault. On the rectified outcrop image, the fault-layer intersection (cut-off line) is identified on either side of the fault trace and a line is drawn to connect the corresponding intersections. The length of this line represents the magnitude of fault separation along the fault trace. Then the displacement magnitude is assigned to the midpoints of each displacement vector (Fig. 3.16). The midpoints of the displacement vectors are interpolated by 'inverse distance weighted' method based on the magnitude, to approximate the displacement values for places where the piercing points could not be identified. The output is a map classified by displacement magnitudes. 


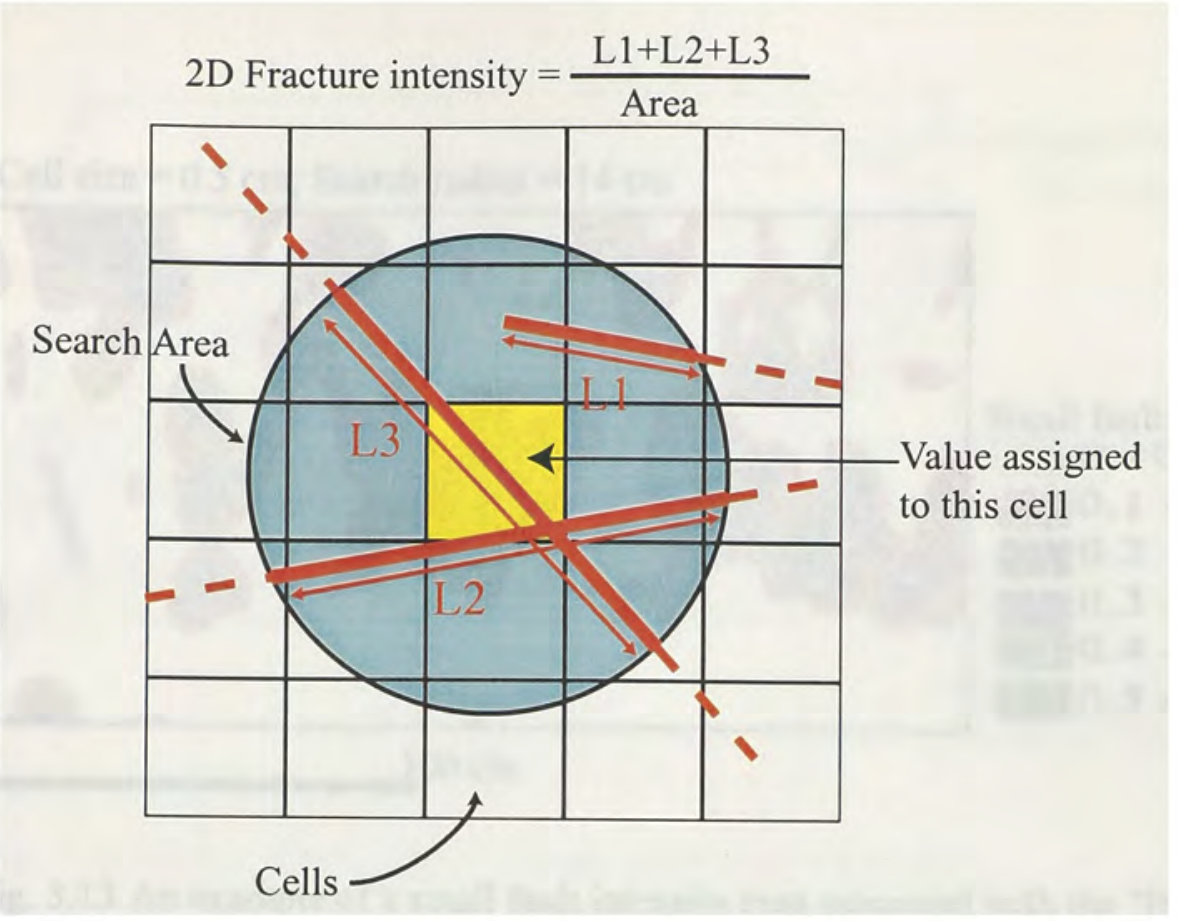

Fig. 3.11 Schematic diagram demonstrating Arc Info "linedensity" routine. The 2D fracture intensity for each cell is calculated as the sum total of all fracture lengths within a prescribed search area.

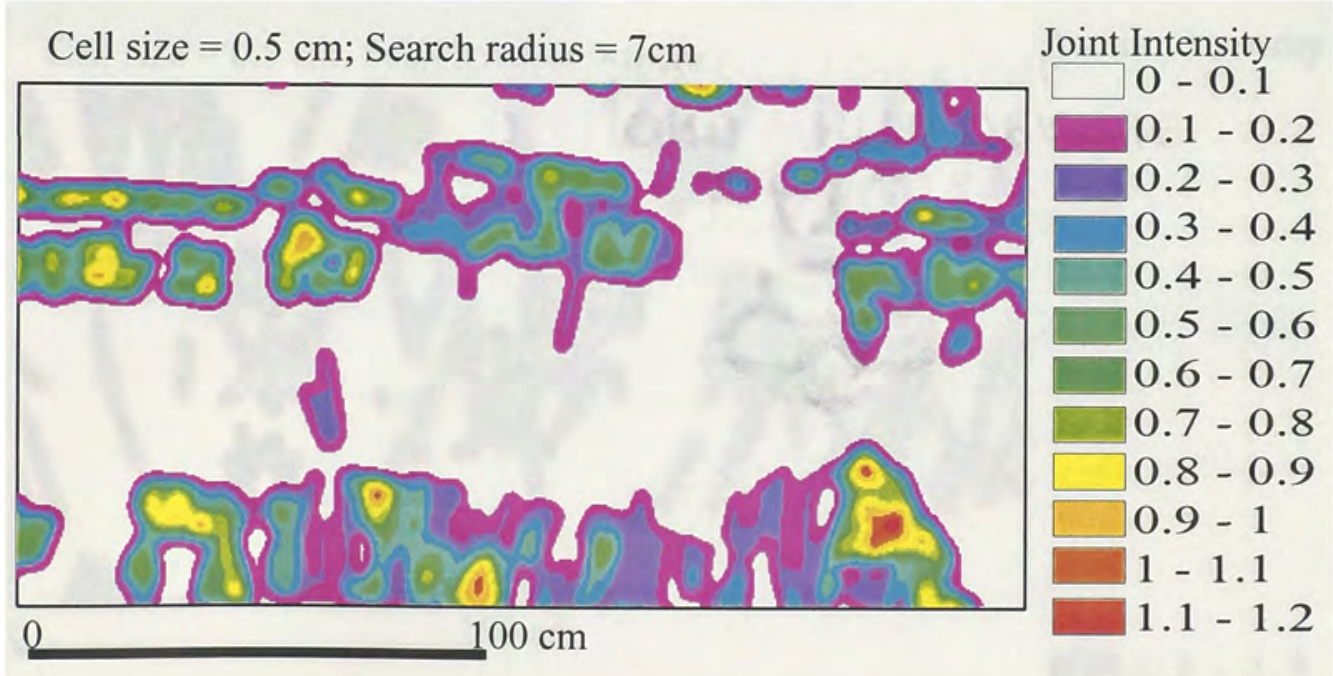

Fig. 3.12 An example of a joint intensity map generated with the "linedensity" function. 


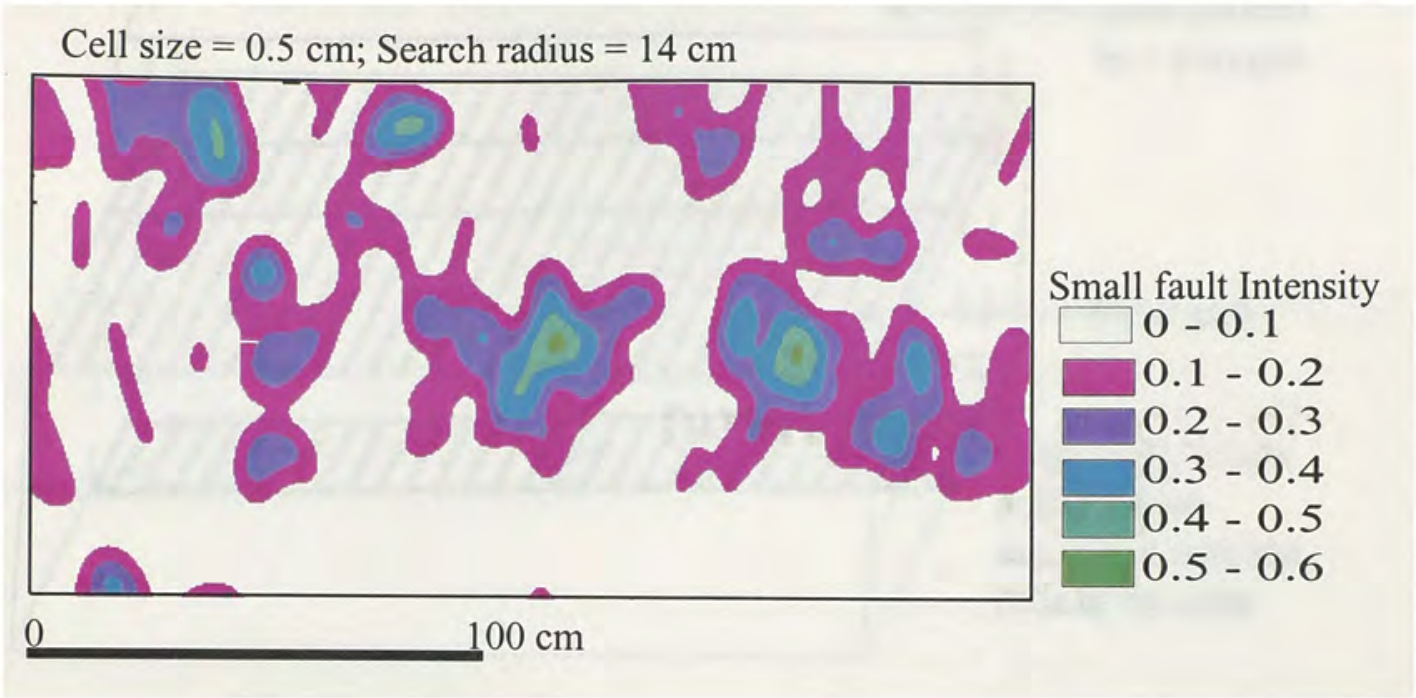

Fig. 3.13 An example of a small fault intensity map generated with the "linedensity" function.

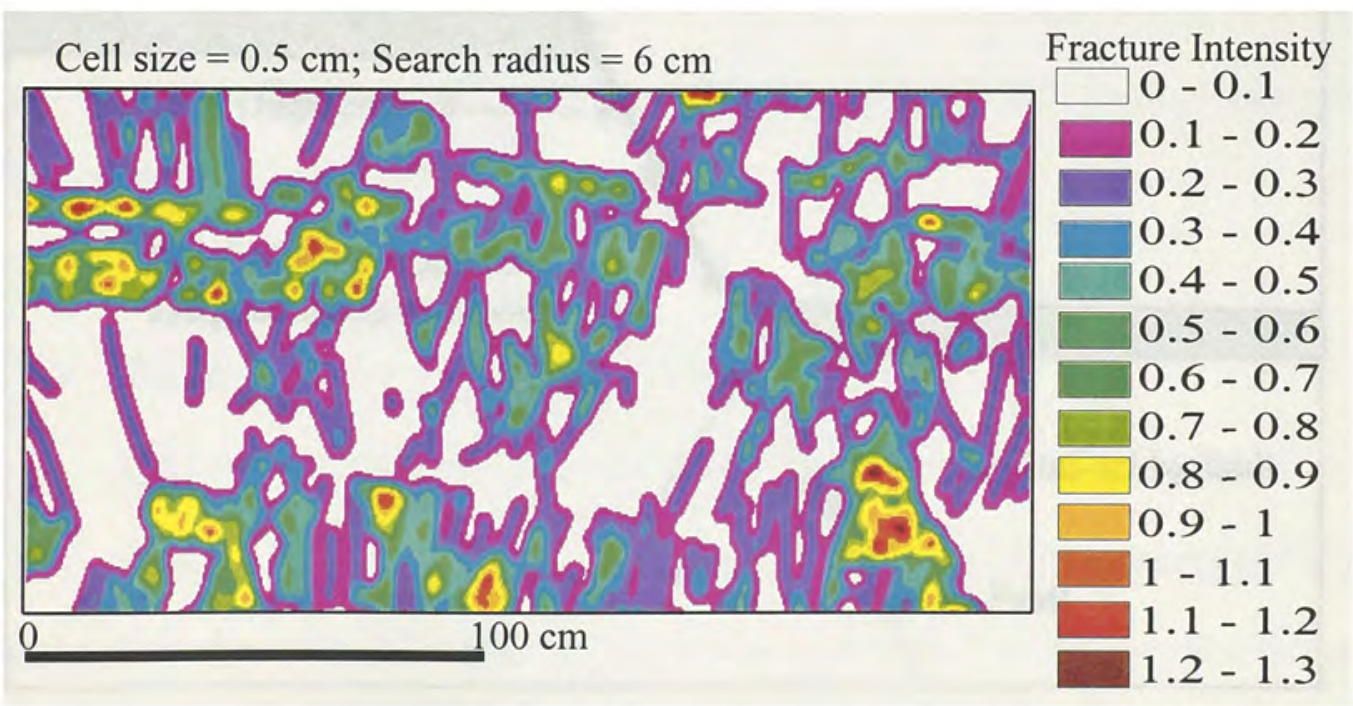

Fig. 3.14 An example of a fracture intensity (joints and small faults together) map generated with the "linedensity" function. 


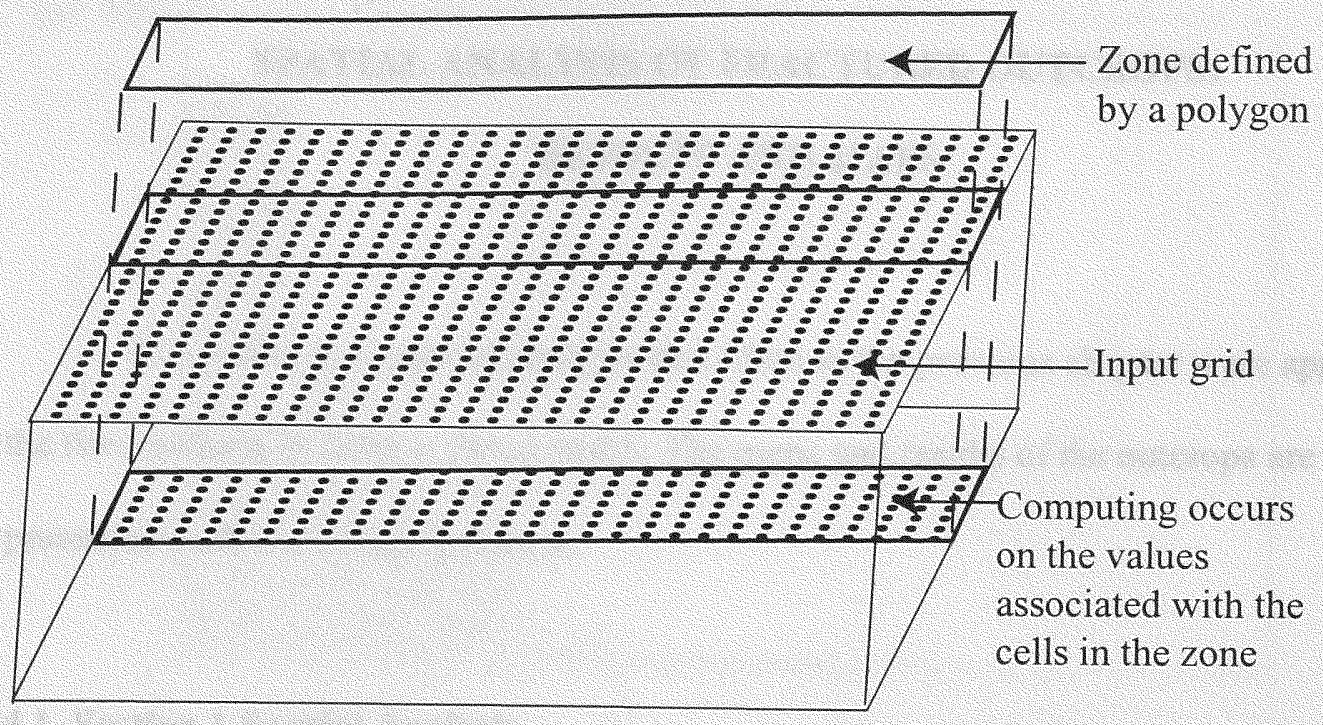

Fig. 3.15 Sketch illustrating the "summarize zone" function.

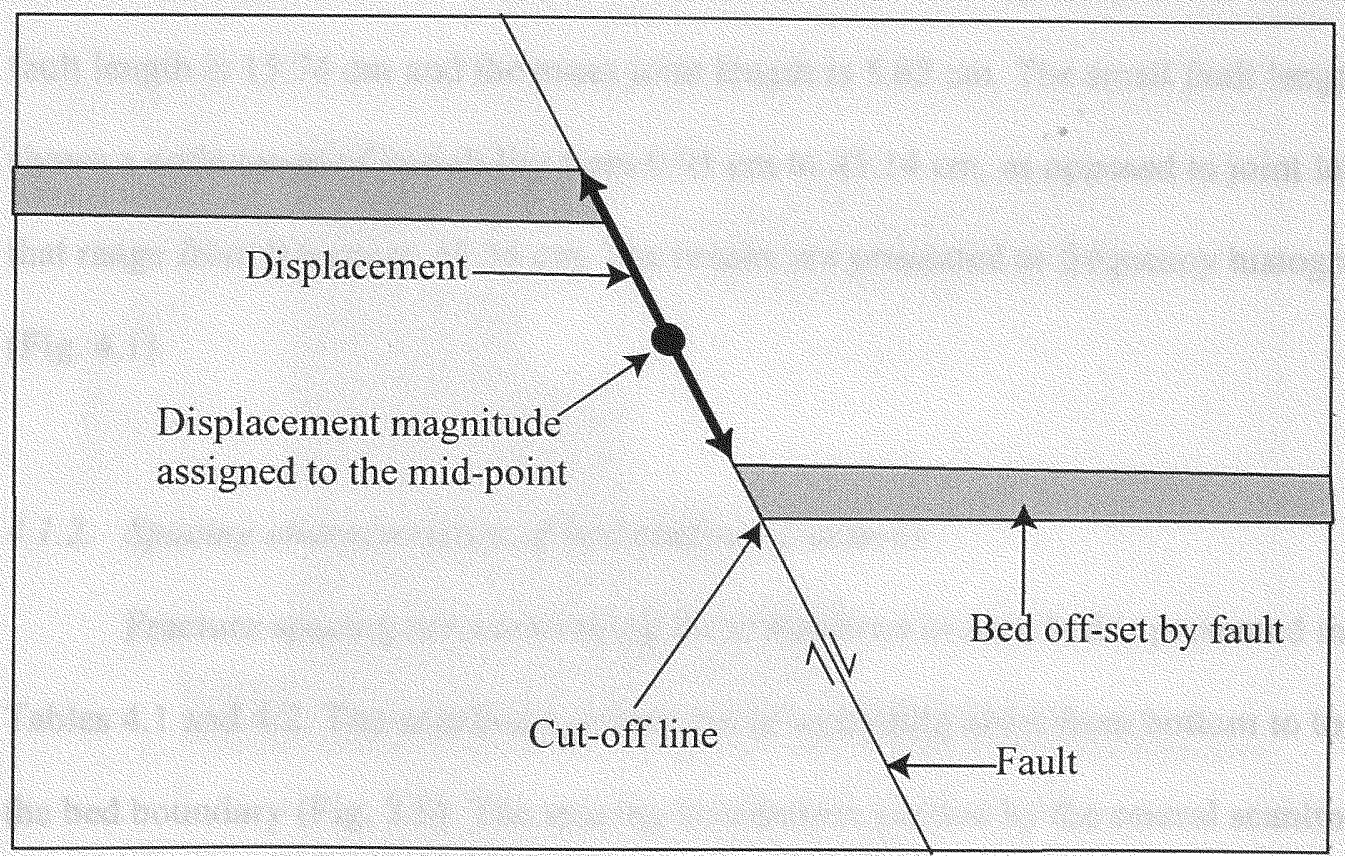

Fig. 3.16 Sketch illustrating method of fault displacment measurement from 2D fracture map. 


\section{CHAPTER 4}

\section{SPATIAL ANALYSIS OF FRACTURED OUTCROPS: \\ RESULTS AND MAPS}

The methods of spatial analysis described in the previous chapter were applied to the two sections at Arroyo Burro beach. The maps and results of the outcrops are presented in the following sections.

\subsection{Section 1 Spatial Analysis}

\subsubsection{Length characteristics of bed confined fractures}

The length pattern of the joints and small faults are very distinct. The mean small fault length is $15.74 \mathrm{~cm}$ and the mean joint length is $5.82 \mathrm{~cm}$. The small fault length also shows a wide range of variability from $0.91 \mathrm{~cm}$ to $45.14 \mathrm{~cm}$, as opposed to joint lengths that range from $0.6 \mathrm{~cm}$ to $35.35 \mathrm{~cm}$. The results are presented as frequency histograms (Fig. 4.1).

\subsubsection{Spacing characteristics of bed confined fractures}

Fracture spacing measured along three scanlines in each bed is presented in Tables 4.1 and 4.2. The scanline numbers are in ascending order from bottom to top of the bed boundary (Fig. 3.5). The spacing distribution yielded by the central scanline in each bed is plotted as frequency histograms (Figs. 4.2, 4.3). The average joint spacing is $2.02 \mathrm{~cm}$ and the median spacing is $1.7 \mathrm{~cm}$, which indicates that the spacing distribution is 

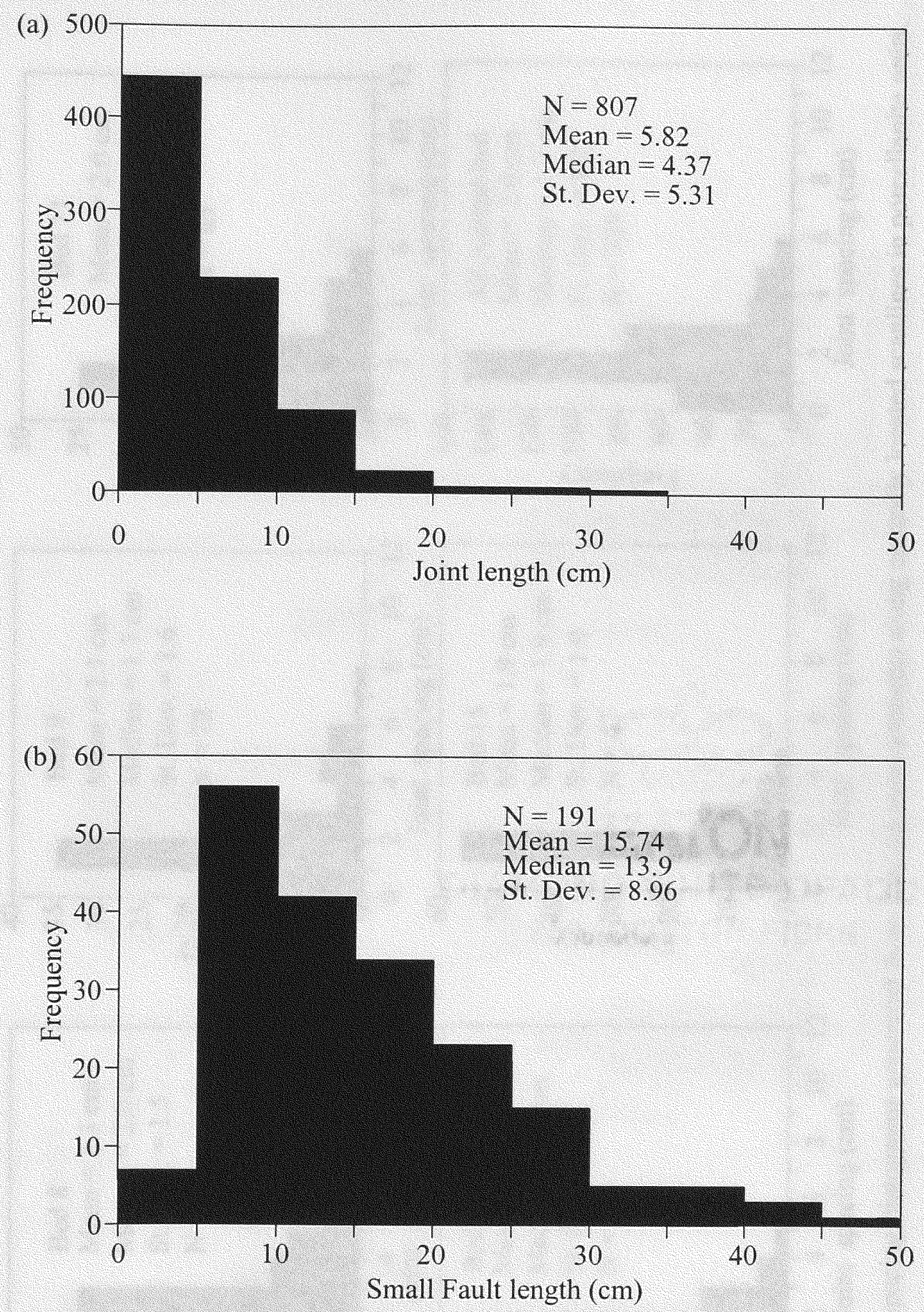

Fig. 4.1 Frequency histograms of (a) joint length and (b) small fault length measured at Section 1. 


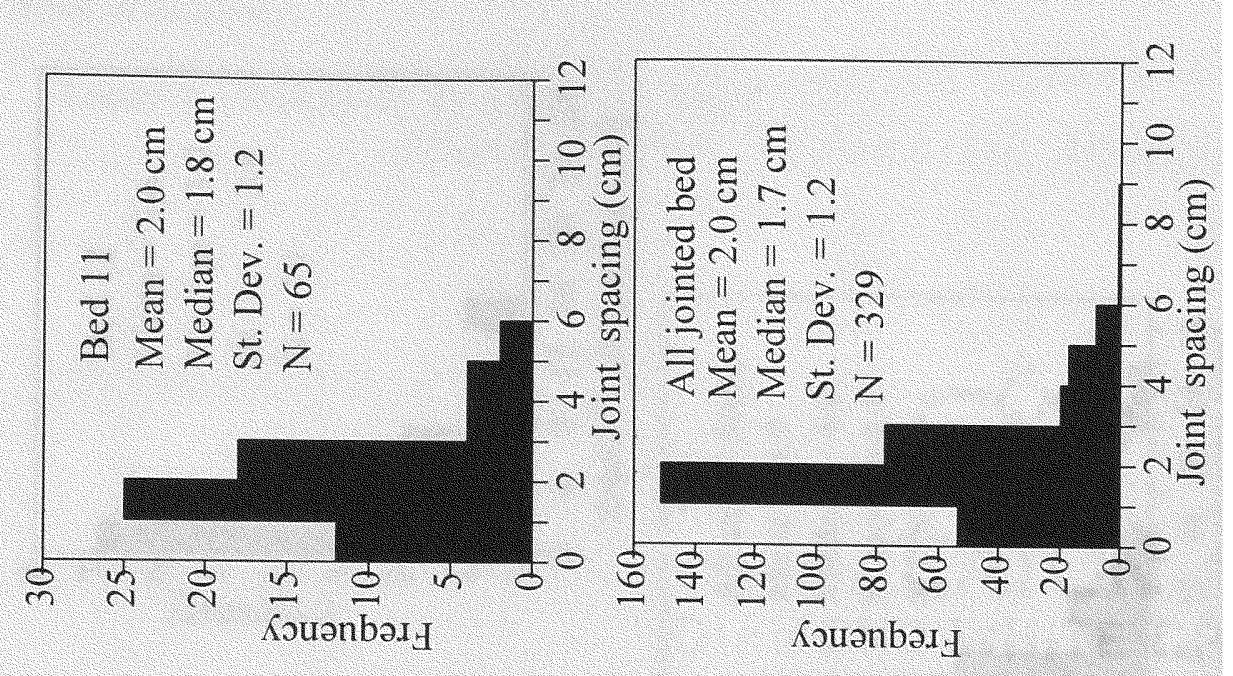

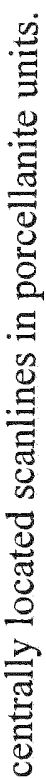

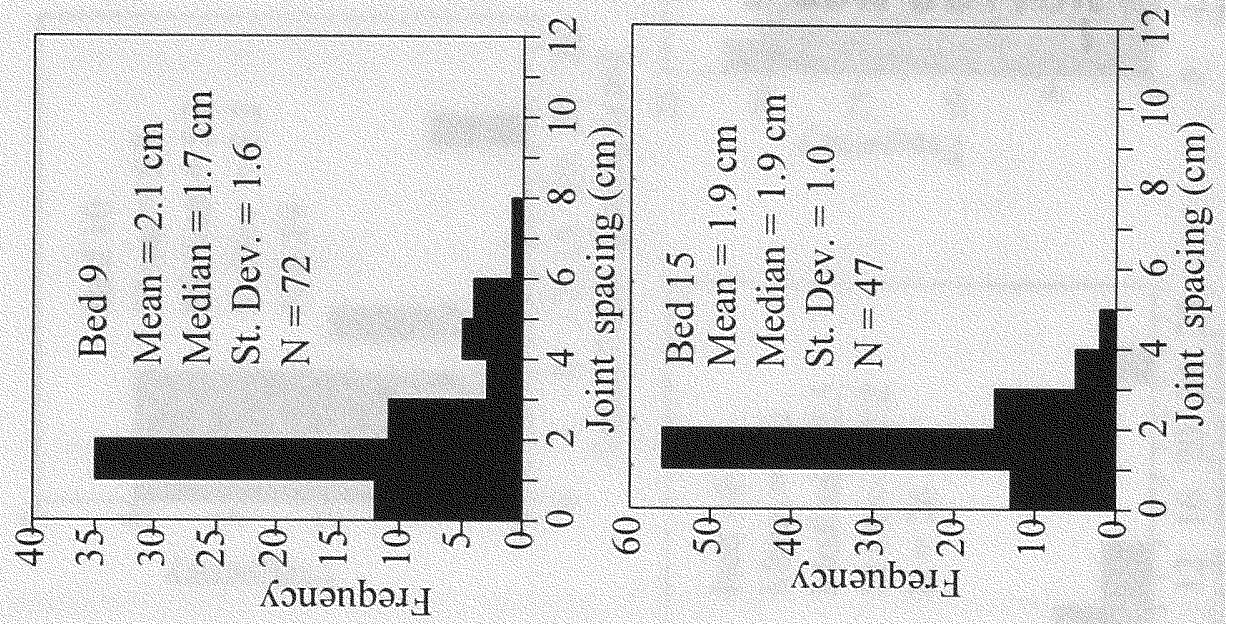

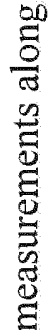
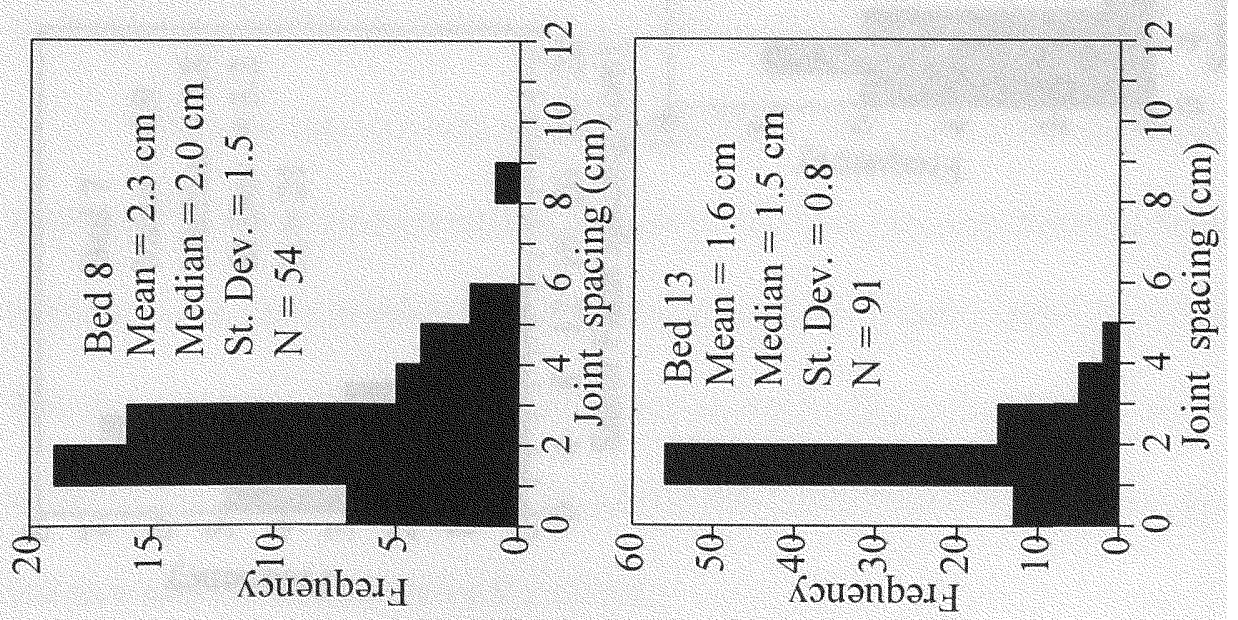

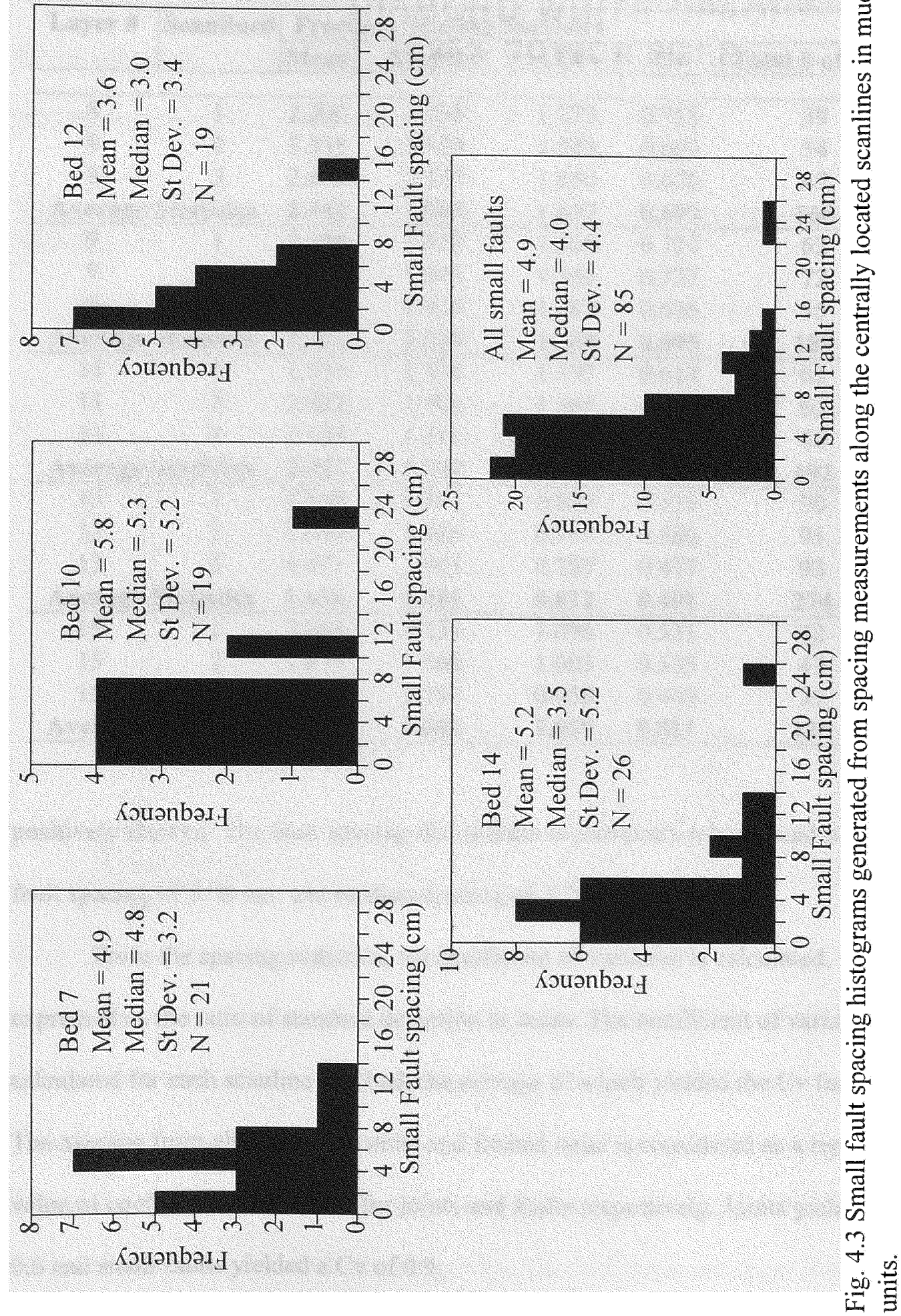
Table 4.1. Table showing joint spacing statistics along 3 scanlines within porcellanite units of Section 1.

\begin{tabular}{|c|c|c|c|c|c|c|}
\hline \multirow[t]{2}{*}{ Layer \# } & \multirow[t]{2}{*}{ Scanline\# } & \multicolumn{5}{|c|}{ Fracture Spacing Statistics } \\
\hline & & Mean & Median & St.Dev. & $\mathrm{Cv}$ & Total \# of data \\
\hline 8 & 1 & 2.208 & 1.736 & 1.673 & 0.758 & 59 \\
\hline 8 & 2 & 2.335 & 2.034 & 1.549 & 0.663 & 54 \\
\hline 8 & 3 & 2.499 & 2.124 & 1.690 & 0.676 & 47 \\
\hline \multicolumn{2}{|c|}{ Average Statistics } & 2.347 & 1.965 & 1.637 & 0.699 & 160 \\
\hline 9 & 1 & 2.296 & 1.628 & 1.660 & 0.723 & 62 \\
\hline 9 & 2 & 2.121 & 1.681 & 1.563 & 0.737 & 72 \\
\hline 9 & 3 & 2.368 & 1.939 & 1.483 & 0.626 & 55 \\
\hline \multicolumn{2}{|c|}{ Average Statistics } & 2.262 & 1.749 & 1.569 & 0.695 & 189 \\
\hline 11 & 1 & 1.951 & 1.626 & 1.197 & 0.614 & 61 \\
\hline 11 & 2 & 2.022 & 1.806 & 1.167 & 0.578 & 65 \\
\hline 11 & 3 & 2.198 & 1.810 & 1.526 & 0.694 & 66 \\
\hline \multicolumn{2}{|c|}{ Average Statistics } & 2.057 & 1.747 & 1.297 & 0.628 & 192 \\
\hline 13 & 1 & 1.638 & 1.391 & 0.843 & 0.515 & 90 \\
\hline 13 & 2 & 1.659 & 1.486 & 0.797 & 0.480 & 91 \\
\hline 13 & 3 & 1.671 & 1.565 & 0.797 & 0.477 & 93 \\
\hline \multicolumn{2}{|c|}{ Average Statistics } & 1.656 & 1.481 & 0.812 & 0.491 & 274 \\
\hline 15 & 1 & 2.065 & 2.131 & 1.096 & 0.531 & 42 \\
\hline 15 & 2 & 1.875 & 1.868 & 1.003 & 0.535 & 47 \\
\hline 15 & 3 & 2.045 & 2.158 & 0.958 & 0.469 & 39 \\
\hline \multicolumn{2}{|c|}{ Average Statistics } & 1.995 & 2.052 & 1.019 & 0.511 & 128 \\
\hline
\end{tabular}

positively skewed. The fault spacing distribution is also positively skewed with a mean fault spacing of $5.08 \mathrm{~cm}$, and median spacing of $3.76 \mathrm{~cm}$.

From the spacing statistics, the coefficient of variation is calculated, which is expressed as the ratio of standard deviation to mean. The coefficient of variation is calculated for each scanline in a bed, the average of which yielded the $\mathrm{Cv}$ for each bed. The average from all the jointed units and faulted units is considered as a representative value of coefficient of variation for joints and faults respectively. Joints yielded a $\mathrm{Cv}$ of 0.6 and small faults yielded a $\mathrm{Cv}$ of 0.9 . 
The fracture spacing measured in this study is the apparent spacing. Since the angle between the average fracture orientation and the trend of the scanlines is very small ( $5^{\circ}$ for joints and $12^{\circ}$ for small faults), the cosine correction required to get the true spacing is minimal ( 0.996 for joints and 0.978 for small faults).

Table 4.2. Table showing small fault spacing statistics along 3 scanlines within mudstone units of Section 1.

\begin{tabular}{|c|c|c|c|c|c|c|}
\hline \multirow[t]{2}{*}{ Layer \# } & \multirow[t]{2}{*}{ Scanline\# } & \multicolumn{5}{|c|}{ Fracture Spacing Statistics } \\
\hline & & Mean & Median & St.Dev. & $\mathrm{Cr}$ & Total \# of data \\
\hline 7 & 2 & 4.952 & 4.824 & 3.248 & 0.656 & 21 \\
\hline 7 & 3 & 4.461 & 3.636 & 3.127 & 0.701 & 18 \\
\hline \multicolumn{2}{|c|}{ Average Statistics } & 4.706 & 4.230 & 3.187 & 0.678 & 39 \\
\hline 10 & 1 & 4.421 & 4.904 & 4.511 & 1.021 & 17 \\
\hline 10 & 2 & 5.832 & 5.303 & 5.185 & 0.889 & 19 \\
\hline 10 & 3 & 4.336 & 2.810 & 4.505 & 1.039 & 31 \\
\hline \multicolumn{2}{|c|}{ Average Statistics } & 4.863 & 4.339 & 4.734 & 0.983 & 67 \\
\hline 12 & 1 & 3.218 & 2.674 & 3.366 & 1.046 & 22 \\
\hline 12 & 2 & 3.563 & 3.045 & 3.399 & 0.954 & 19 \\
\hline 12 & 3 & 3.803 & 3.111 & 3.670 & 0.965 & 17 \\
\hline \multicolumn{2}{|c|}{ Average Statistics } & 3.528 & 2.943 & 3.478 & 0.988 & 58 \\
\hline 14 & 1 & 7.835 & 5.618 & 6.762 & 0.863 & 20 \\
\hline 14 & 2 & 5.162 & 3.487 & 5.208 & 1.009 & 26 \\
\hline 14 & 3 & 7.329 & 4.886 & 7.051 & 0.962 & 19 \\
\hline \multicolumn{2}{|c|}{ Average Statistics } & 6.775 & 4.664 & 6.340 & 0.945 & 65 \\
\hline
\end{tabular}

\subsubsection{Fracture intensity results}

The joint intensity statistics extracted from the matrix of cells in the grid, yielded a mean value of $0.14 / \mathrm{cm}$ for (Figs. $4.4,4.5$ ) with a range of intensity varying from 0 $1.2 / \mathrm{cm}$. The average joint intensity, for porcellanite units is $0.35 / \mathrm{cm}$ as opposed to $0.03 / \mathrm{cm}$ in the mudstone units. On the other hand, the small fault intensity yielded a bulk value of $0.08 / \mathrm{cm}$ for the whole area (Fig. 4.6). The fault intensity ranges from 0 to a 


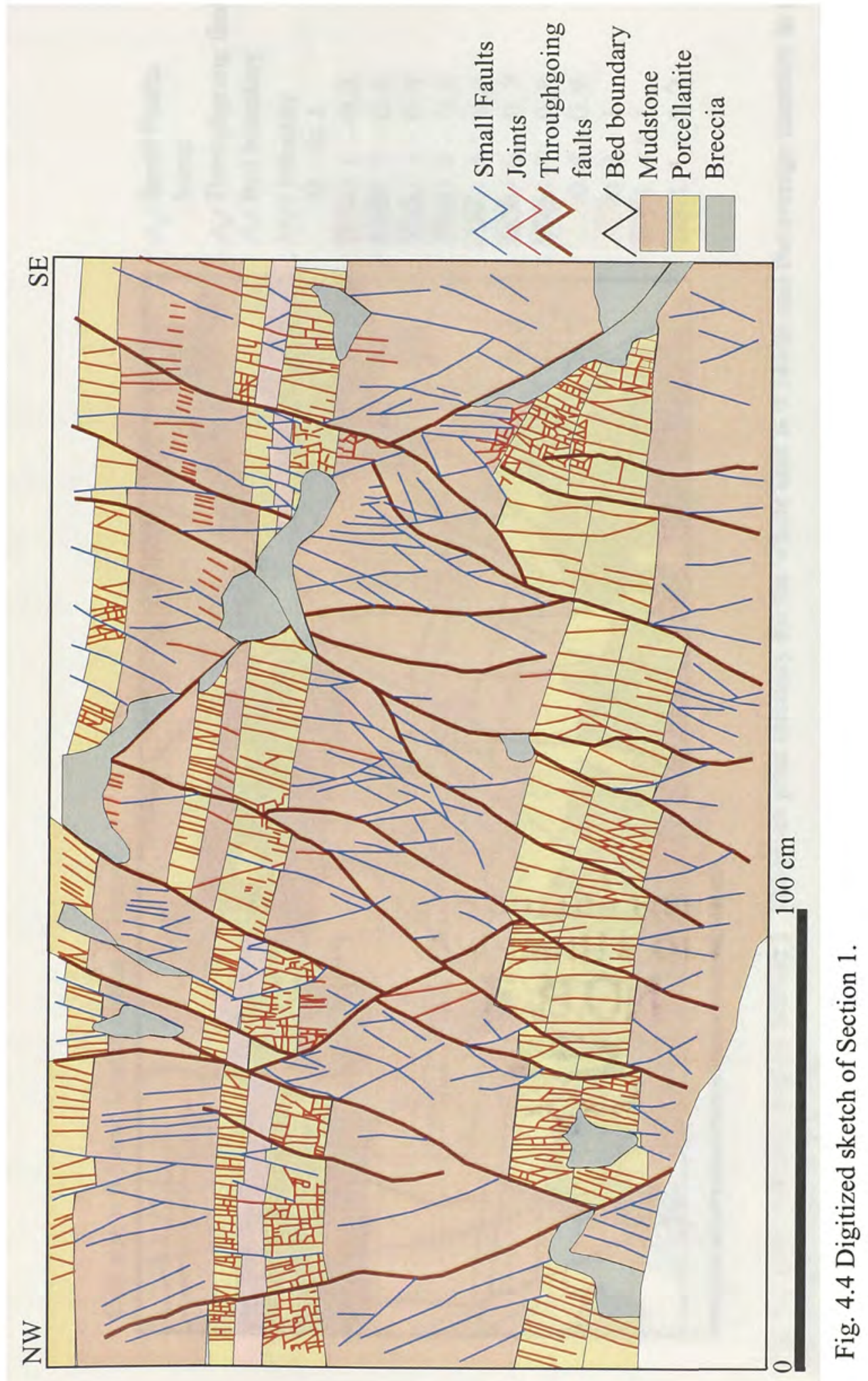




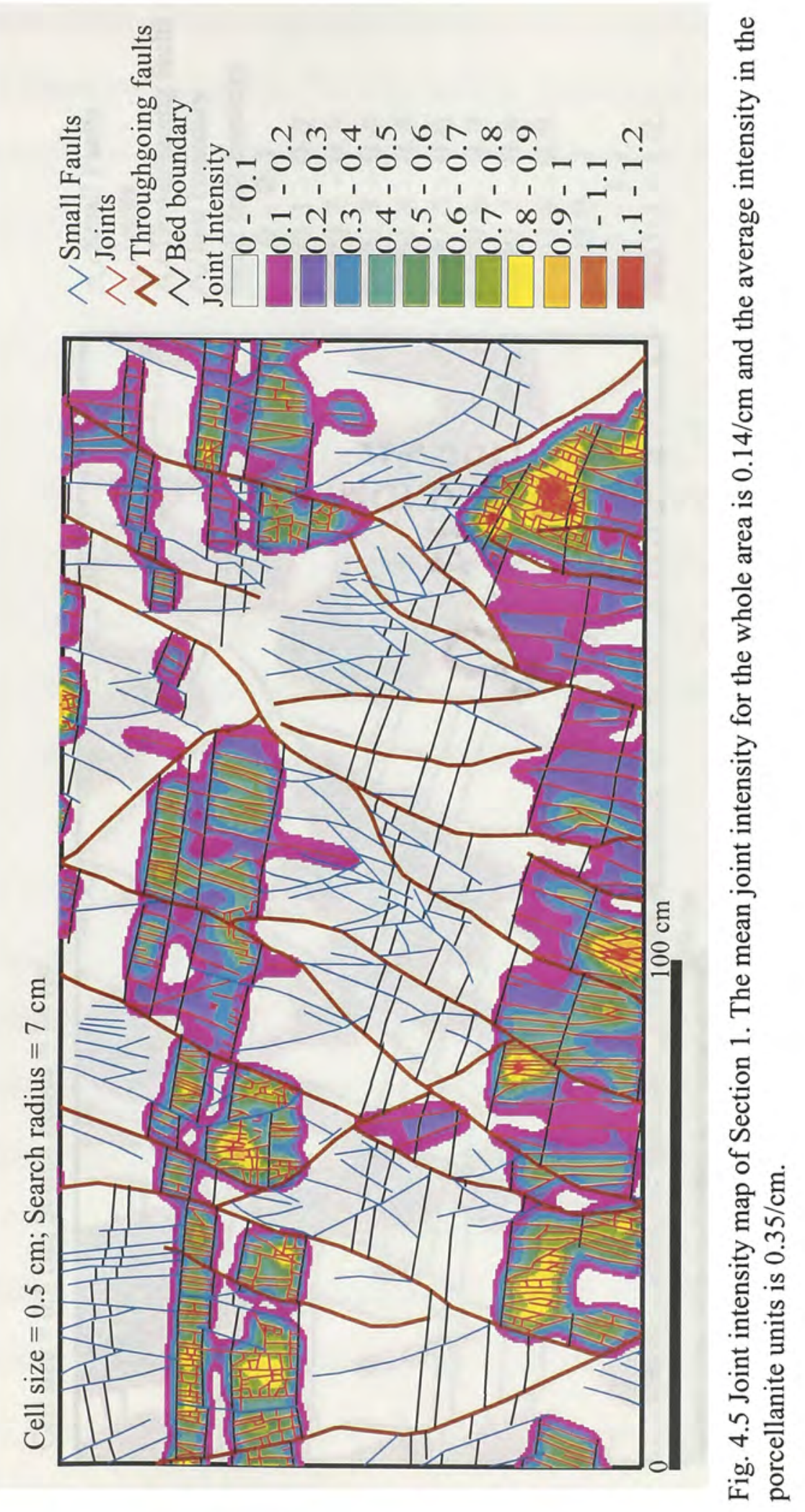




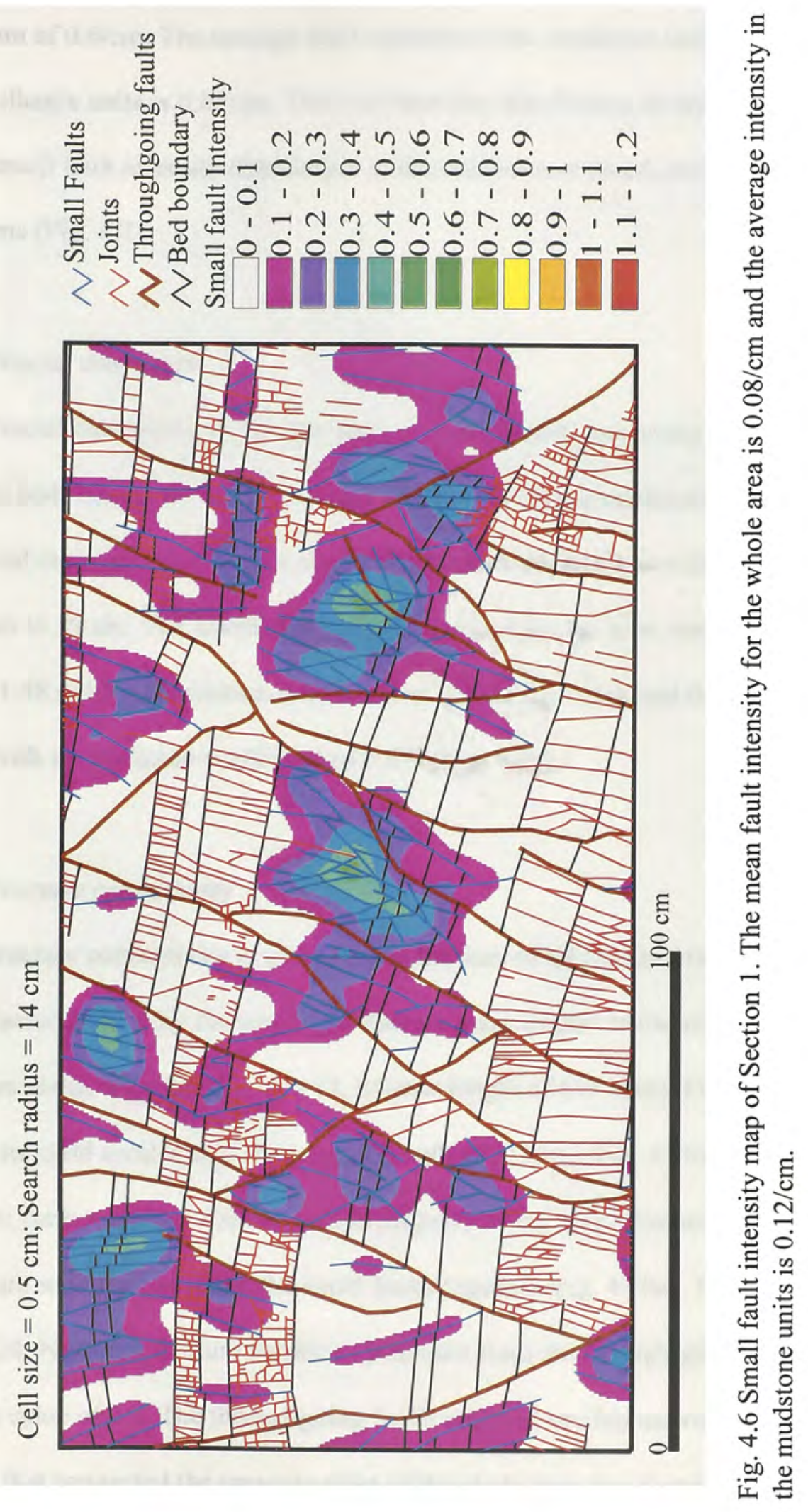


maximum of $0.6 / \mathrm{cm}$. The average fault intensity in the mudstone units is $0.12 / \mathrm{cm}$ and in the porcellanite units is $0.05 / \mathrm{cm}$. The joint intensity distribution in the porcellanite units and the small fault intensity distribution in the mudstone units are presented as frequency histograms (Fig. 4.7).

\subsubsection{Fractal dimension}

Fractal dimension, D, for the joints and small faults, occurring in porcellanite and mudstone beds respectively, were calculated using the box counting method. The analysis was carried out over 1.3 orders of magnitude for both populations with box sizes ranging from $1 \mathrm{~cm}$ to $20 \mathrm{~cm}$. The fractal dimension calculated for the joint network yielded a value of 1.48 (with a correlation coefficient of 0.99) (Fig. 4.8a), and that for small faults is 1.27 (with a correlation coefficient of 0.99) (Fig. 4.8b).

\subsubsection{Fracture connectivity}

Fracture connectivity is quantified as the sum of all fracture trace lengths in the largest cluster divided by the sum of all fracture trace lengths in the study area. The joint population yields a cluster size of 0.14 , (cluster length of $613.4 \mathrm{~cm}$ ) (Fig. 4.9a) and the small faults yield a value of 0.09 , (cluster length of $212 \mathrm{~cm}$ ) (Fig. $4.9 \mathrm{~b}$ ).

To further analyze the conductive property of the entire fracture network a cluster map is built with the joints and the small faults together (Fig. 4.10a). The resulting cluster size is 0.24 . Next, the fracture cluster is generated from the through-going faults, it yielded a value of 0.8 . The throughgoing faults returned one big network of connected fractures that connected the opposite sides of the study area thus forming a fracture 


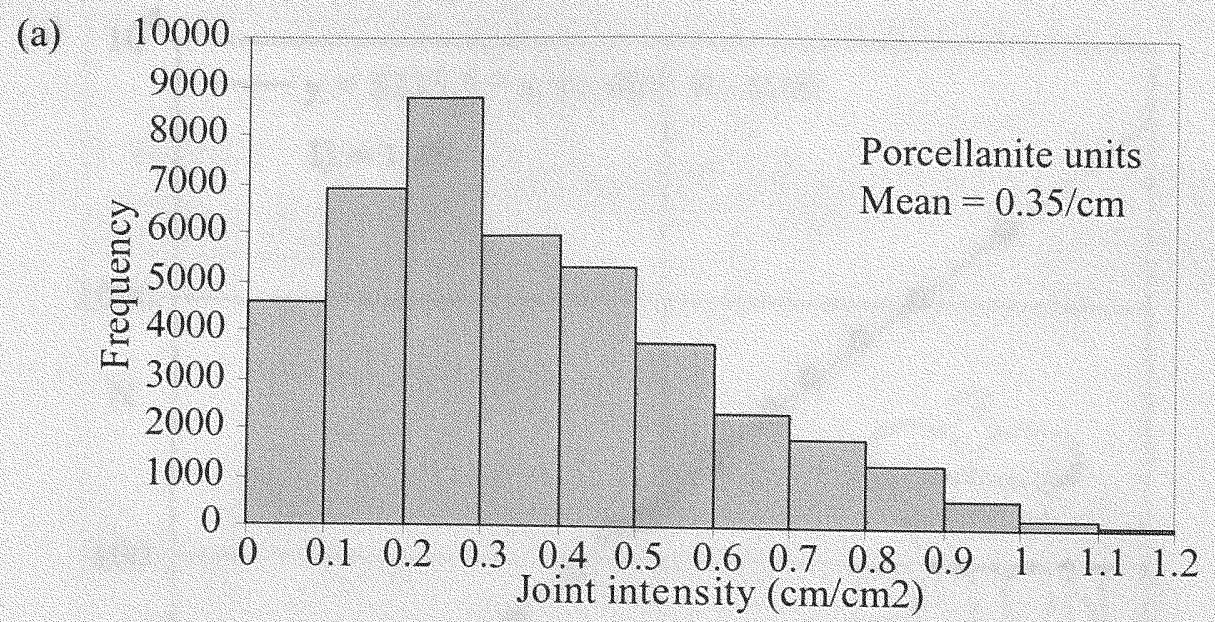

(b)

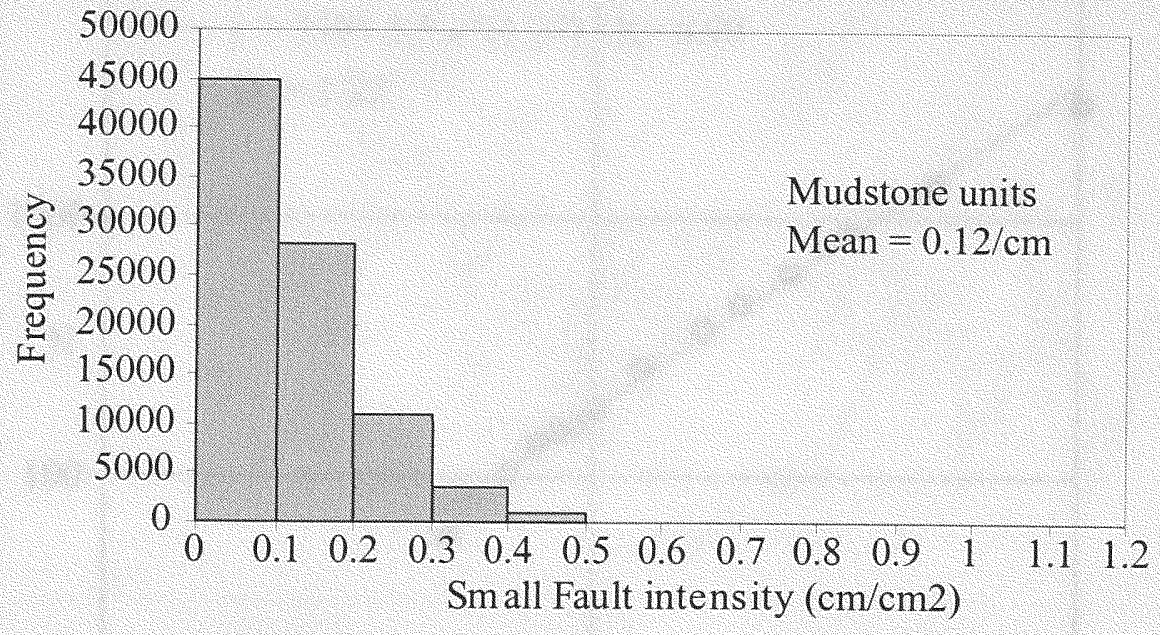

Fig. 4.7 Fracture intensity histograms of (a) joints in porcellanites (b) small faults in mudstones of Section 1. 


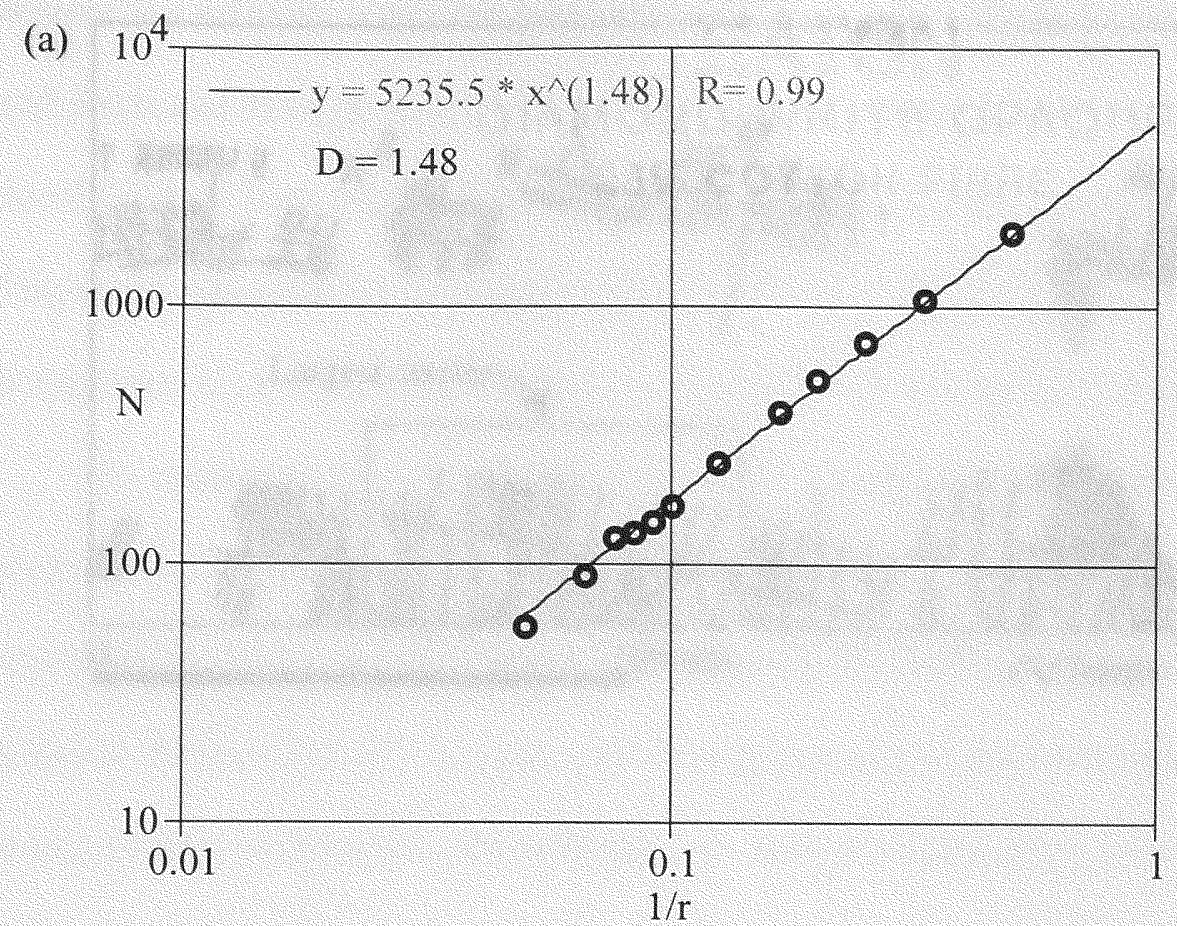

(b)

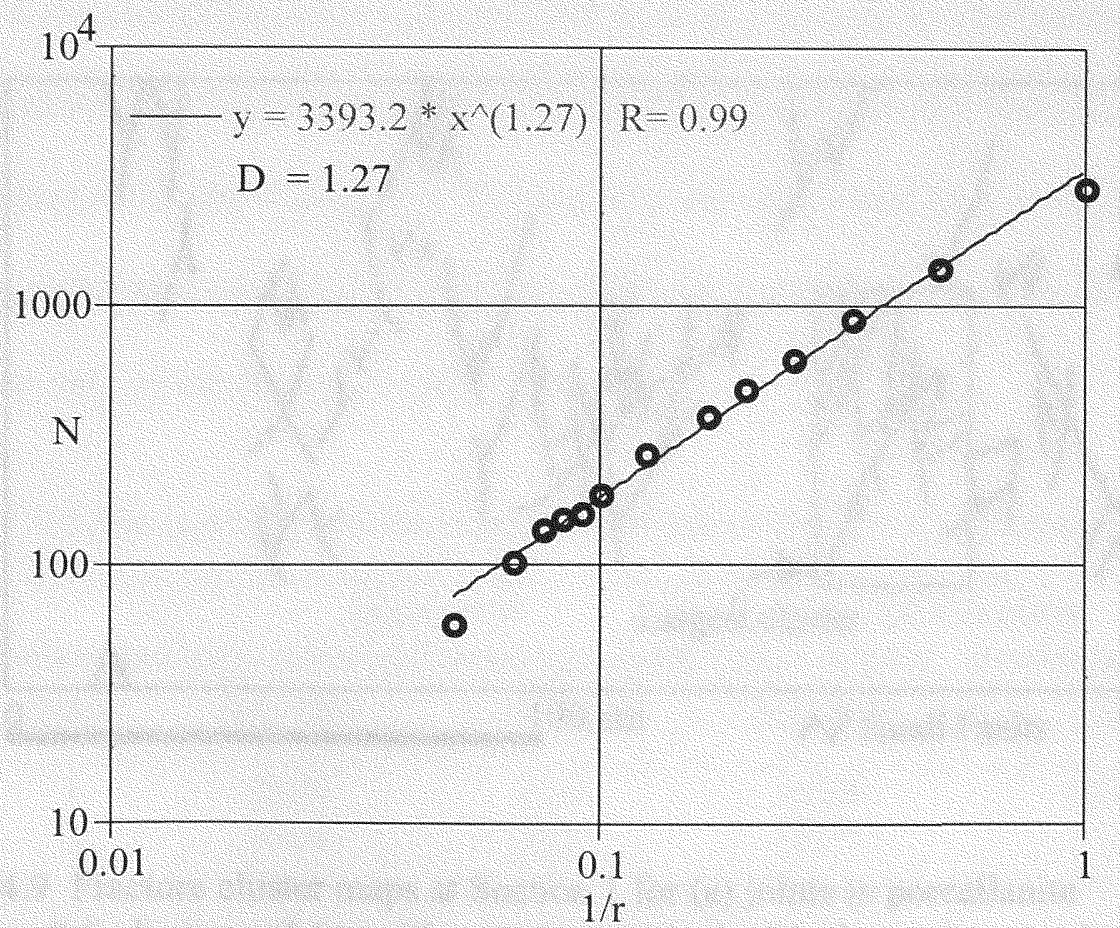

Fig. 4.8 Fractal dimension plots for (a) joints in porcellanite (b) small faults in mudstone of Section $1 . \mathrm{N}=$ Number of cells intersected by a fracture, $\mathrm{r}=$ cell size. 
(a)

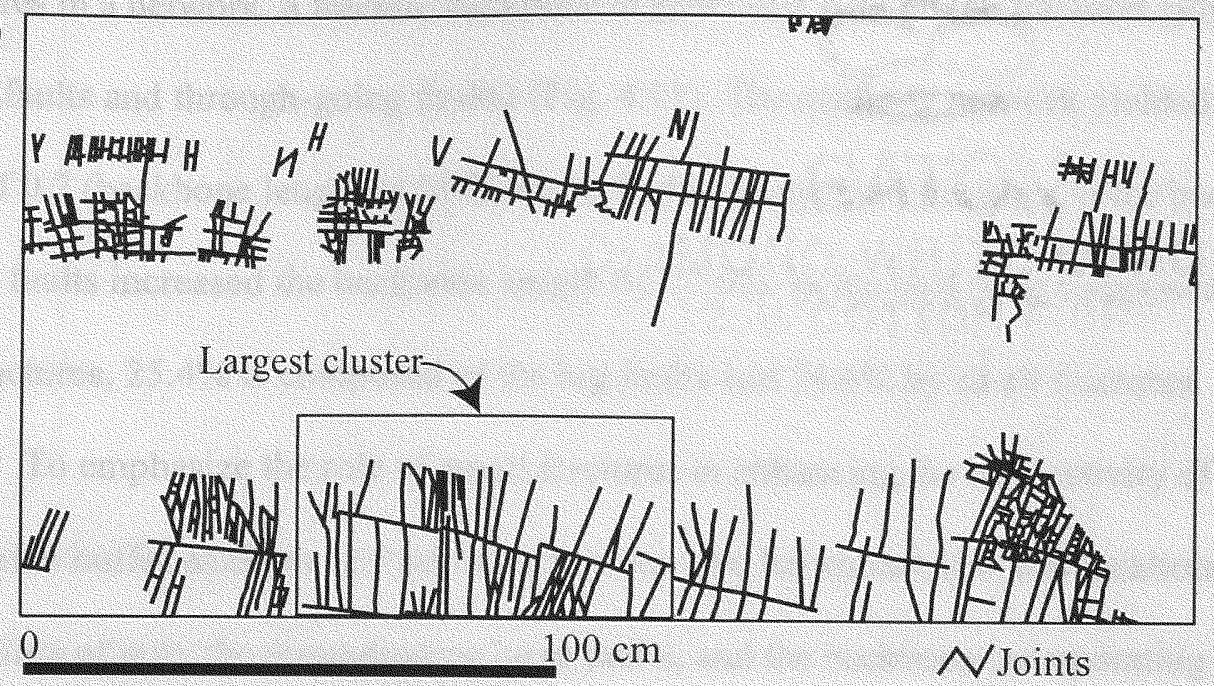

(b)

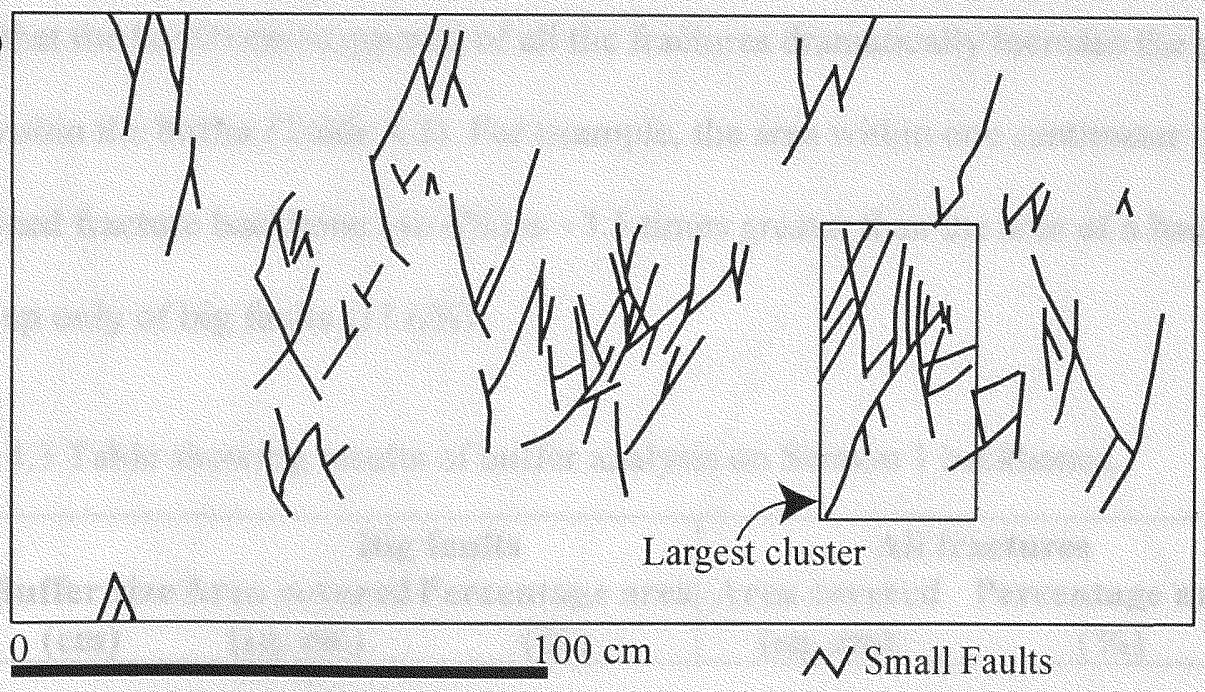

Fig. 4.9 Fracture cluster maps at Section 1 for (a) joints in porcellanite

(b) small faults in mudstone. The cluster within the box is the largest cluster of the respective fracture network. 
backbone (backbone length of $1271.3 \mathrm{~cm}$ ) (Fig. $4.10 \mathrm{~b}$ ). To analyze the effect of small fractures in a network, a fracture backbone is generated with all the fractures (joints, small faults and through-going faults) (Fig. 4.11). The resulting network yielded a cluster size of 0.7 (backbone length of $5672.9 \mathrm{~cm}$ ). Inclusion of small fractures in the backbone of big faults increased the backbone length by $77.6 \%$. In the backbone composed of all the fractures, $25.4 \%$ is composed of the big faults and $74.6 \%$ by small fractures.

To emphasize the role of small fractures in enhancing the connectivity of the network a buffer analysis was performed on the two backbones (i.e. the backbone consisting of only the throughgoing large faults, and the backbone incorporating all the fractures). Buffer sizes of 1 through $5 \mathrm{~cm}$ were drawn around the backbones to compare the area of rock within a prescribed distance to two backbones (Figs. $4.12-4.16$ ). The result is presented as a percent of total rock area in proximity to the backbone. The results show that the backbone composed of all the fractures dramatically increase the percent area within the buffer (Table 4.3). For example, the area within one centimeter of the combined fracture backbone $(40.6 \%)$ is $\sim 3.5$ times greater than the area of a backbone made up only of big faults (11.6\%).

Table 4.3 Table showing results of buffer analysis on Section 1 backbones.

\begin{tabular}{|c|c|c|c|c|}
\hline & & & All I & actures \\
\hline $\begin{array}{c}\text { Buffer si } \\
(\mathrm{cm})\end{array}$ & $\begin{array}{r}\text { rea cover } \\
(\mathrm{sq} \cdot \mathrm{cm})\end{array}$ & $\begin{array}{l}\text { ntage area } \\
(\%)\end{array}$ & $\begin{array}{c}\text { Area covered } \\
(\mathrm{sq} . \mathrm{cm})\end{array}$ & $\begin{array}{c}\text { Percentage area } \\
(\%)\end{array}$ \\
\hline 1 & 2928 & 11.6 & 10269 & 40.6 \\
\hline 2 & 5108 & 20.2 & 14577 & 57.6 \\
\hline 3 & 7369 & 29.1 & 17711 & 70.0 \\
\hline 4 & 9315 & 36.8 & 19784 & 78.2 \\
\hline 5 & 11374 & 45.0 & 21543 & 85.2 \\
\hline
\end{tabular}


(a)

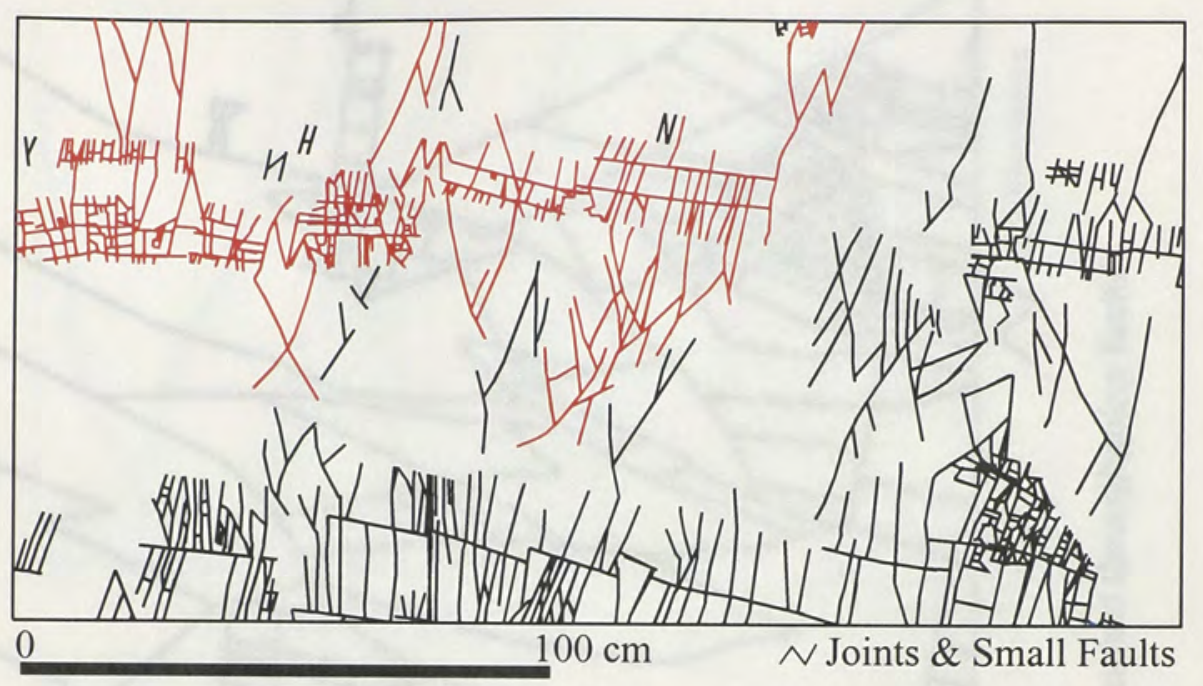

(b)

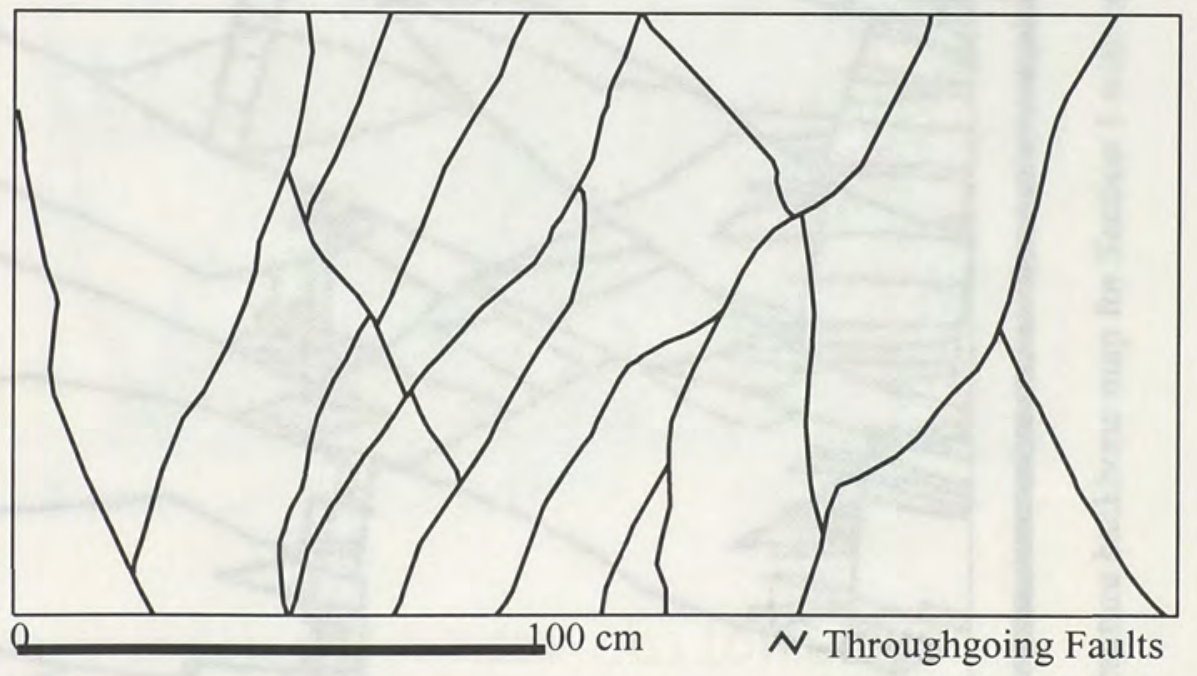

Fig. 4.10 Fracture cluster maps for Section1 for (a) joints and small faults together, fractures belonging to the largest cluster is indicated by red color, and (b) throughgoing faults. 


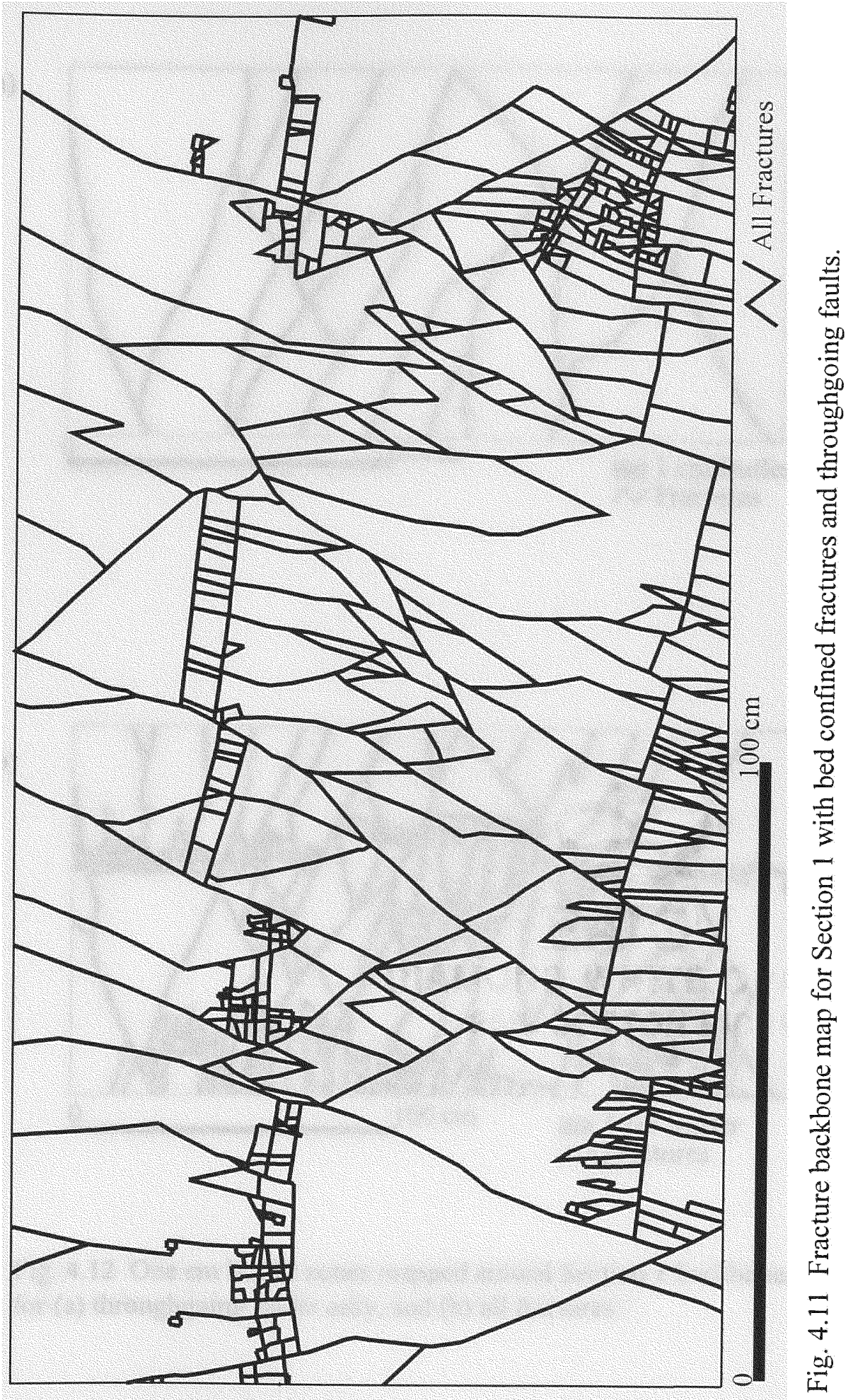


(a)

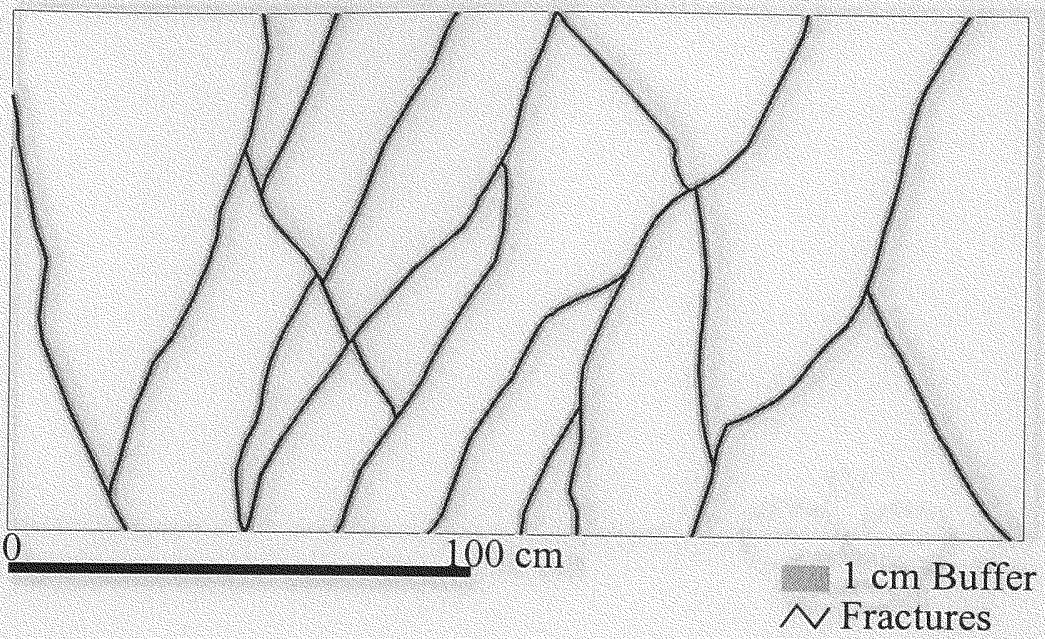

(b)

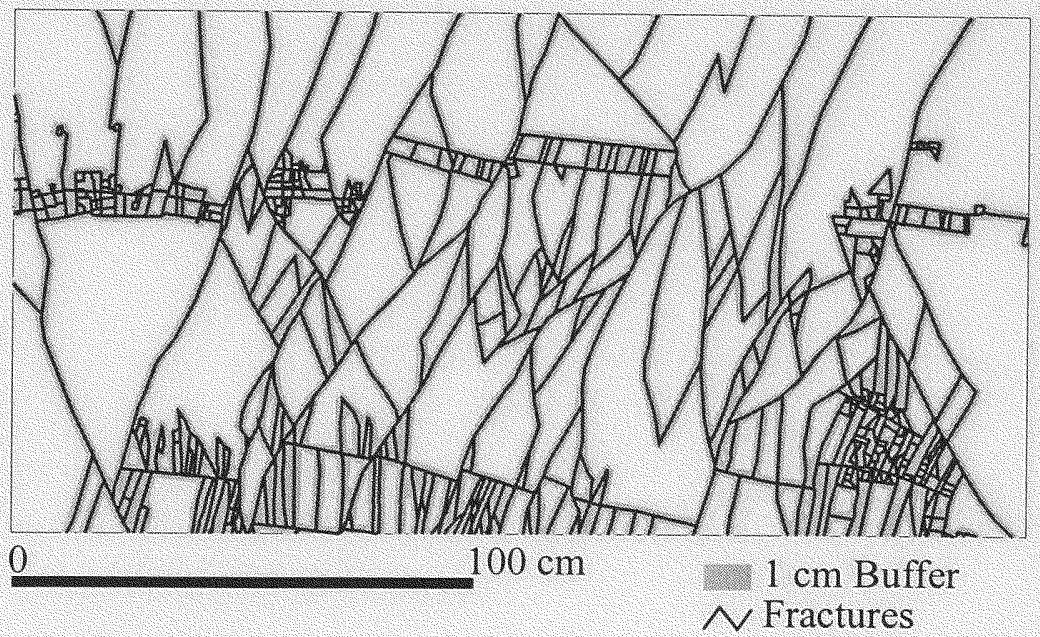

Fig. 4.12 One $\mathrm{cm}$ buffer zones mapped around Section 1 backbones for (a) throughgoing faults only, and (b) all fractures. 
(a)

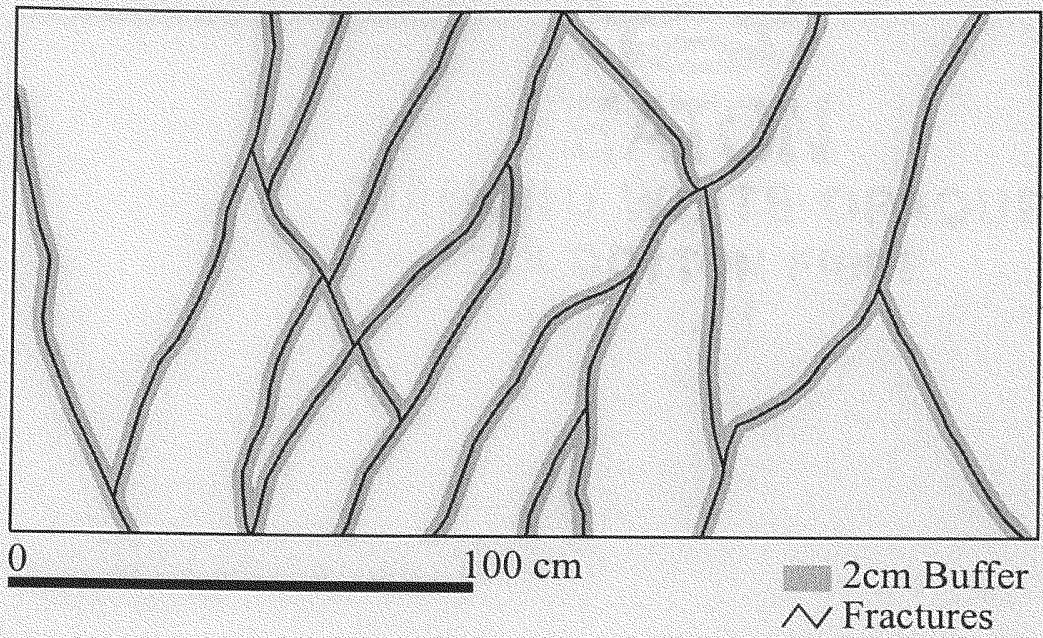

(b)

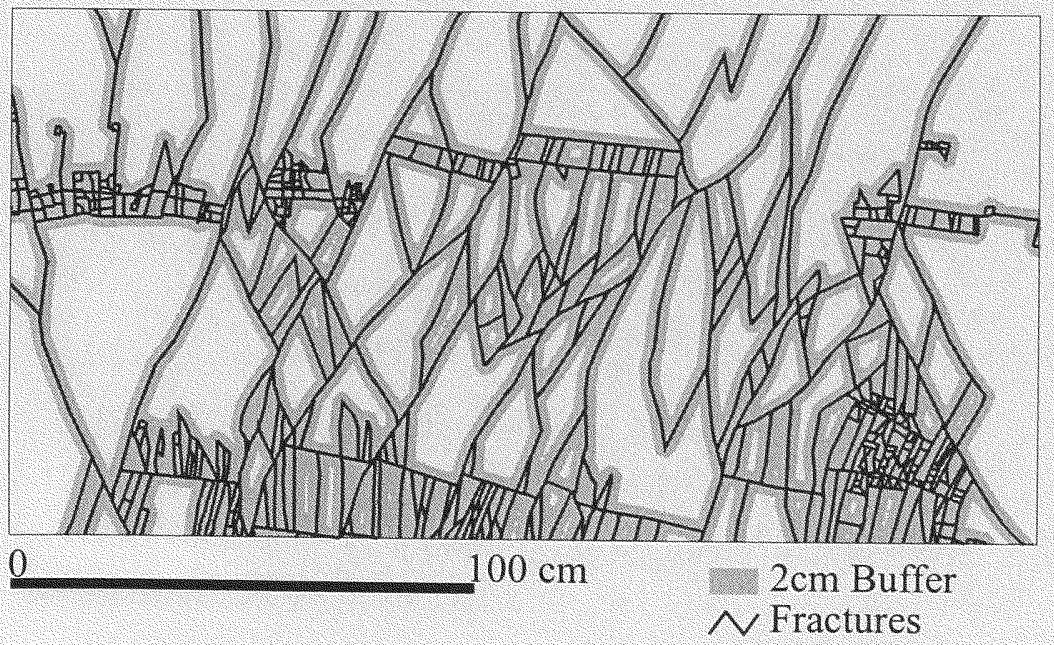

Fig. 4.13 Two $\mathrm{cm}$ buffer zones mapped around Section 1 backbones for (a) throughgoing faults only, and (b) all fractures. 


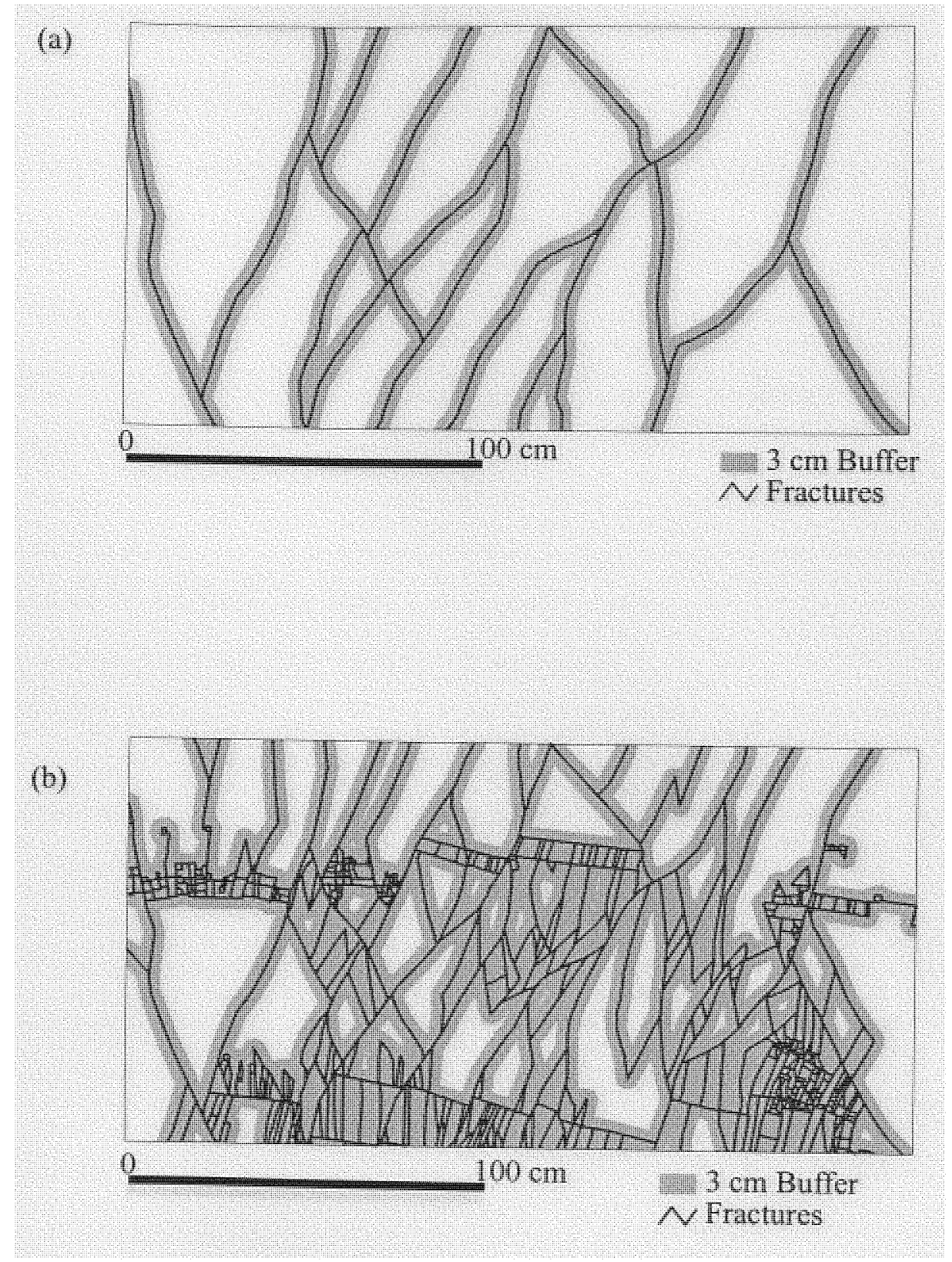

Fig. 4.14 Three $\mathrm{cm}$ buffer zones mapped around Section 1 backbones for (a) throughgoing faults only, and (b) all fractures. 


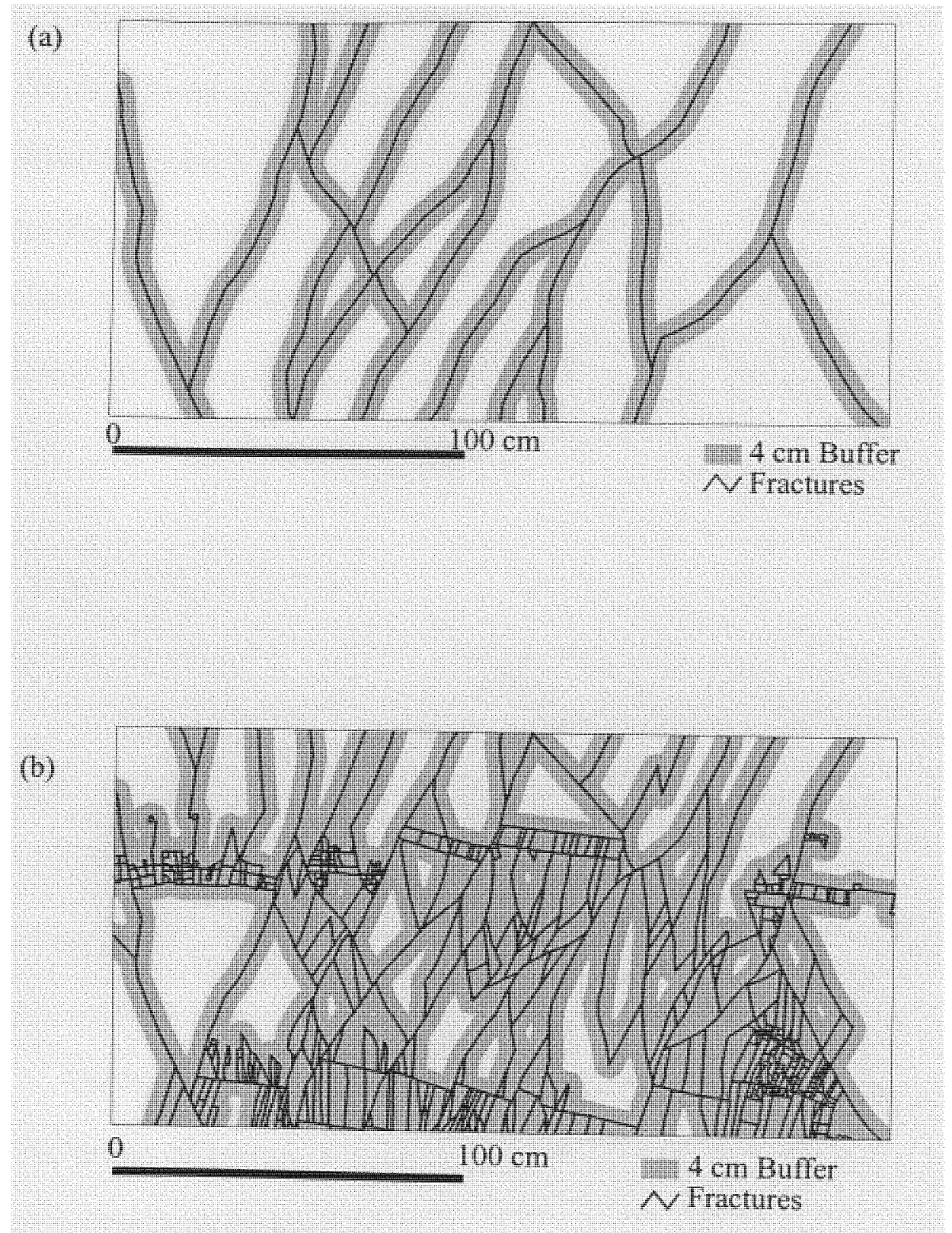

Fig. 4.15 Four $\mathrm{cm}$ buffer zones mapped around Section 1 backbones for (a) throughgoing faults only, and (b) all fractures. 


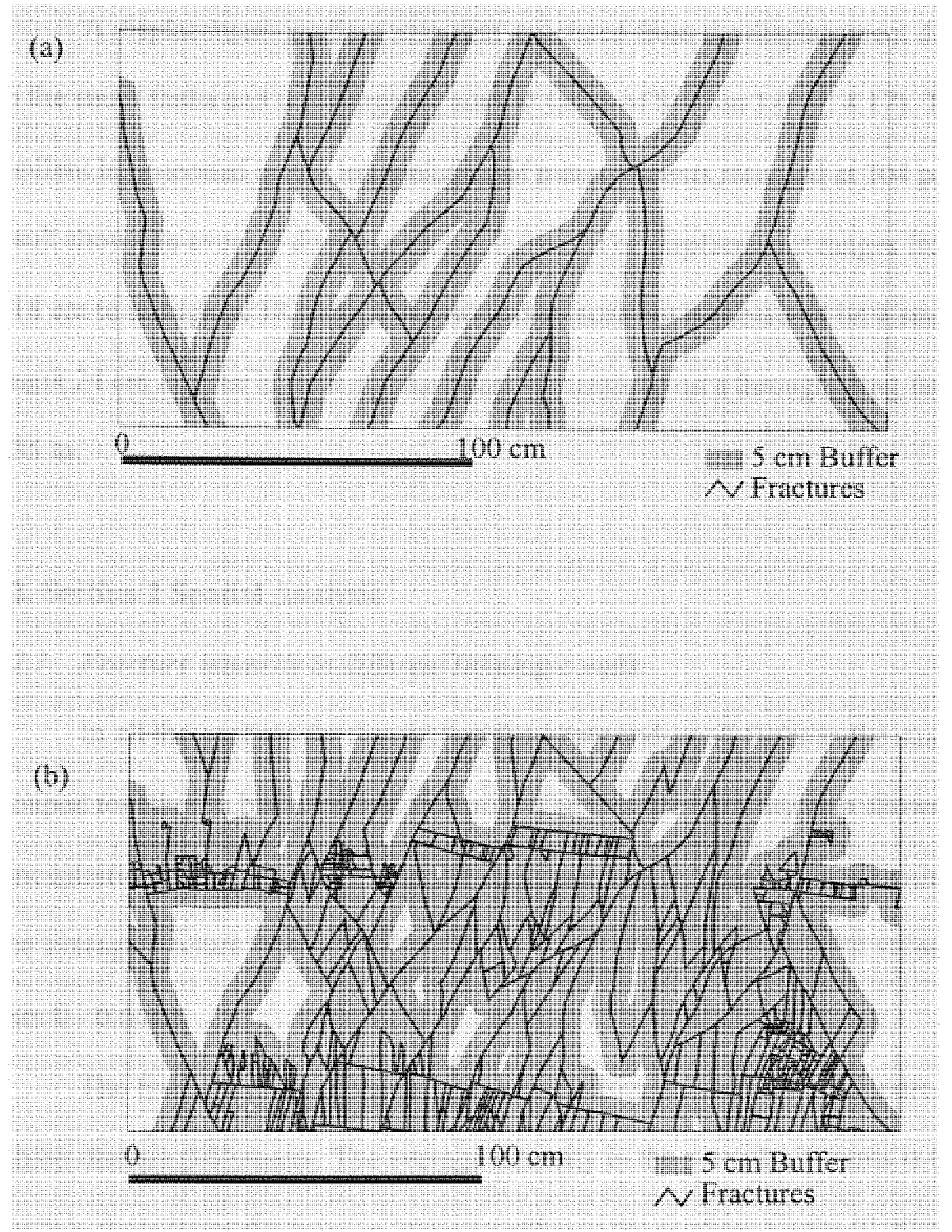

Fig. 4.16 Five $\mathrm{cm}$ buffer zones mapped around Section 1 backbones for (a) throughgoing faults only, and (b) all fractures. 


\subsubsection{Dip separation map of faults of Section I}

A displacement gradient map was generated from the displacement data measured on the small faults and throughgoing normal faults of Section 1 (Fig. 4.17). The gradient is generated by the interpolation of measurements recorded at 304 points. The result shows an average displacement of $2.6 \mathrm{~cm}$. The displacement ranges from as low as $0.18 \mathrm{~cm}$ to as high as $18.1 \mathrm{~cm}$. The lowest displacement is measured on a small fault of length $24 \mathrm{~cm}$ and the highest displacement is measured on a throughgoing fault of length $1.35 \mathrm{~m}$.

\subsection{Section 2 Spatial Analysis}

\subsubsection{Fracture intensity in different lithologic units.}

In all the analysis for this section the joints and small faults in the study area are grouped together as bed-confined fractures. The fracture intensity map shows concentration of high values within the fault zone and in the porcellanite units (Fig. 4.18). The average fracture intensity value for the whole area is $0.09 / \mathrm{cm}$, with values ranging from $0-0.6 / \mathrm{cm}$.

The fracture intensity statistics extracted from the mudstone and porcellanite units exhibit distinct differences. The average intensity in the porcellanite units is $0.27 / \mathrm{cm}$, which is three times the average intensity value in the mudstone units $(0.09 / \mathrm{cm})$. The fracture intensity distribution in the mudstone and porcellanite units is represented in the form of frequency histograms. In mudstones, the intensity statistics show that the mean intensity is considerably greater than the median, representing a skewed distribution (skewness 1.5) (Fig. 4.19a). On the other hand, in the porcellanite unit the mean is 
approximately equal to the median representing a normal distribution (Fig. 4.19b). The statistics of intensity values are presented in Table 4.4 .

Table 4.4 Table showing fracture intensity statistics in different lithologic units of Section 2.

\begin{tabular}{c|ccccc}
\hline \multirow{2}{*}{ Rock Name } & \multicolumn{5}{|c}{ Statistics } \\
\cline { 2 - 6 } & Mean & Median & St. Dev. Variance Skewness \\
\hline Porcellanite & 0.266 & 0.270 & 0.115 & 0.013 & 0.049 \\
Mudstone & 0.089 & 0.070 & 0.078 & 0.006 & 1.560 \\
\hline
\end{tabular}

\subsubsection{Fracture intensity as a function of proximity to large faults.}

Visual inspection of the fracture intensity map of Section 2 reveals that the cells with high intensity values tend to occur close to the big faults (4.17b). To support the visual interpretation, a buffer analysis was performed on the big faults. In this process, a buffer grid is generated for the big faults that covers the area analysis, and from the grid, buffer zones are generated (Fig. 3.12). Three buffer zone intervals of $10 \mathrm{~cm}, 15 \mathrm{~cm}$ and $20 \mathrm{~cm}$ were used in this study. The fracture intensity statistics for each of the buffer zones is extracted and plotted against the distance from the big fault (Fig. 4.20). In all the plots, the trend of scatter shows a decrease in fracture intensity with increasing distance from the big faults. A curve is fitted through the data points to determine the function that best represents the data. This helps to define the spatial variability of fracture distribution and can be used as a model for the prediction of fracture envelope dimensions around subsurface faults. An exponential curve is fit through the scatter, with correlation 
coefficient of $0.95-0.97$. The data is also represented in the form of frequency histograms (Fig. 4.21). 


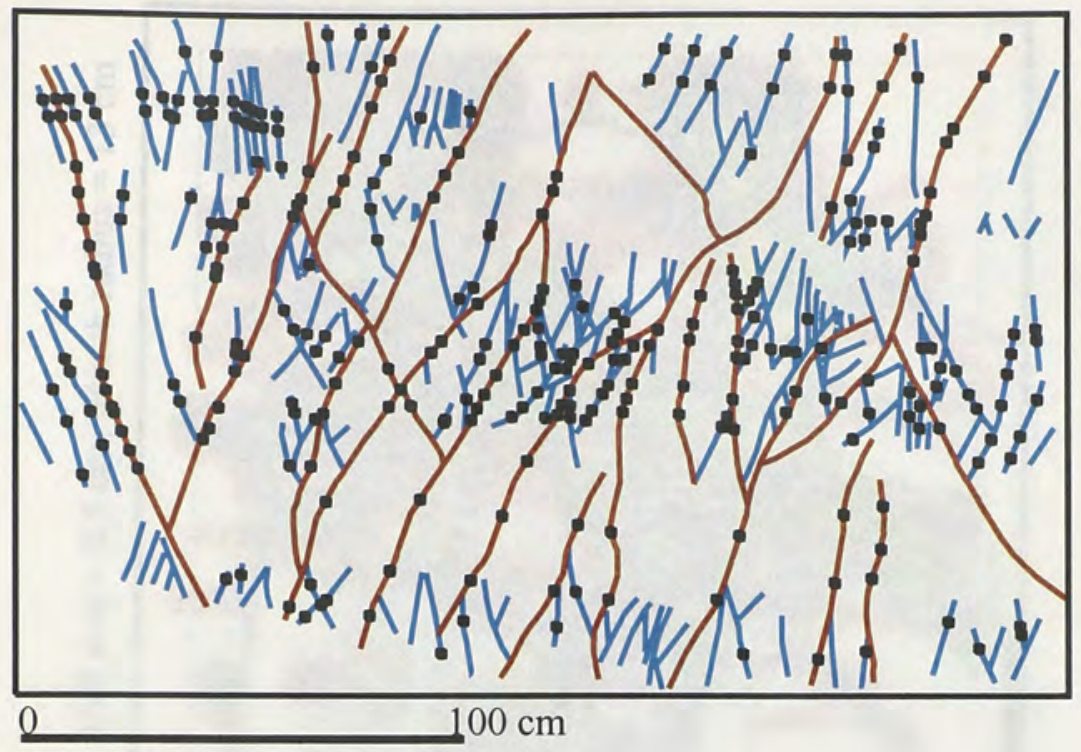

- Location of displacement measurements

$\checkmark$ Throughgoing faults

$\mathcal{N}$ Small faults

Breccia

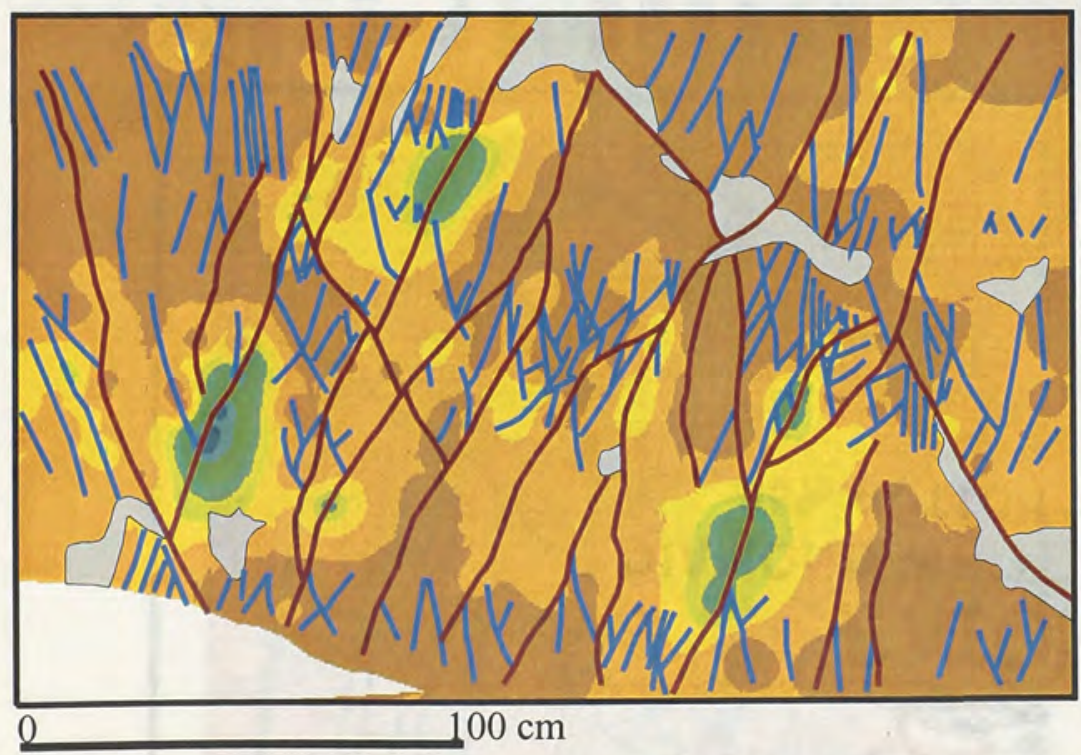

Displacement

Gradient $(\mathrm{cm})$

$\square 0$ - 2

$\square 2-4$

$4-6$

$\square 6-8$

$8-10$

$10-12$

$12-14$

$14-16$

$16-18$

- $18-20$

Fig. 4.17 (a) Fault map of Section 1 with points indicating location of displacement measurements. (b) Dip separation map of faults of Section 1 generated by interpolation of displacement measurements recorded at 304 points. 


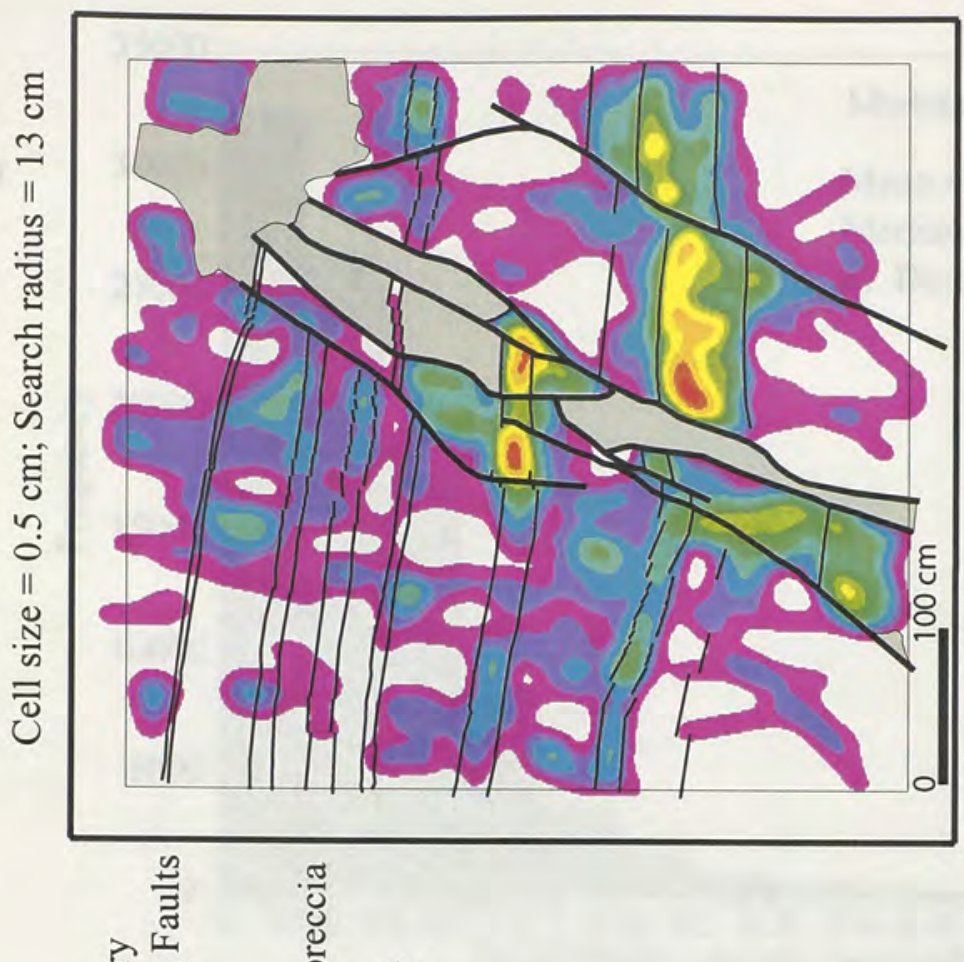

בี

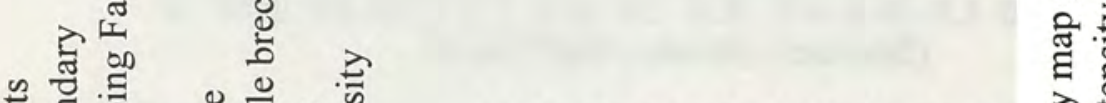
莺苛 $\Omega$ I

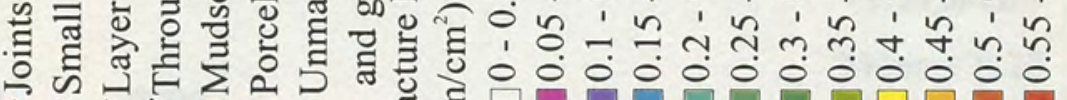
২२ZZ

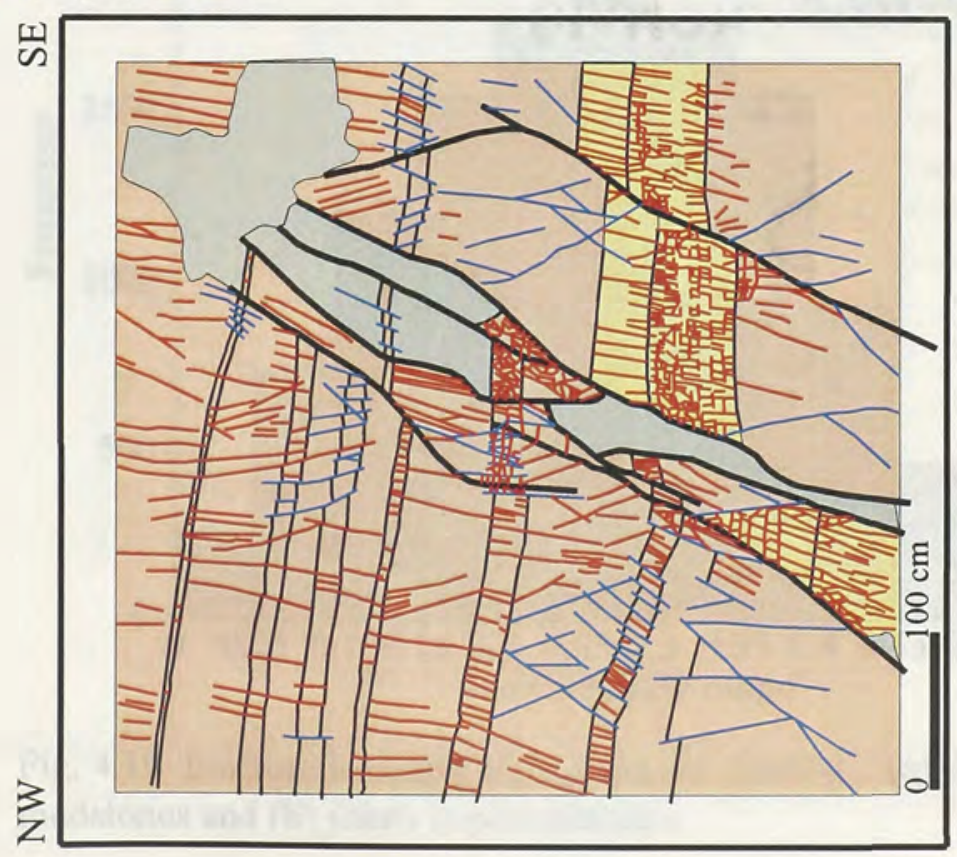

的. 
(a)

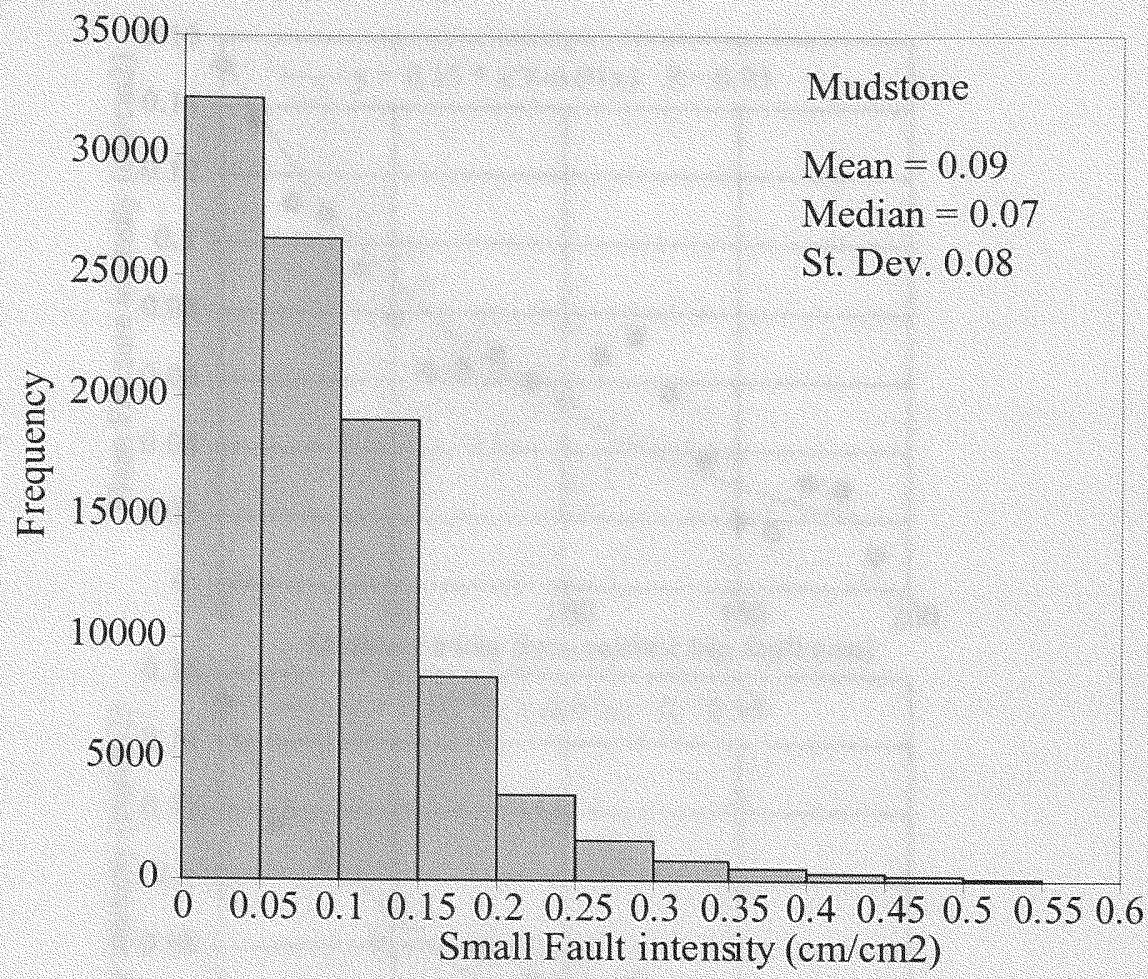

(b)

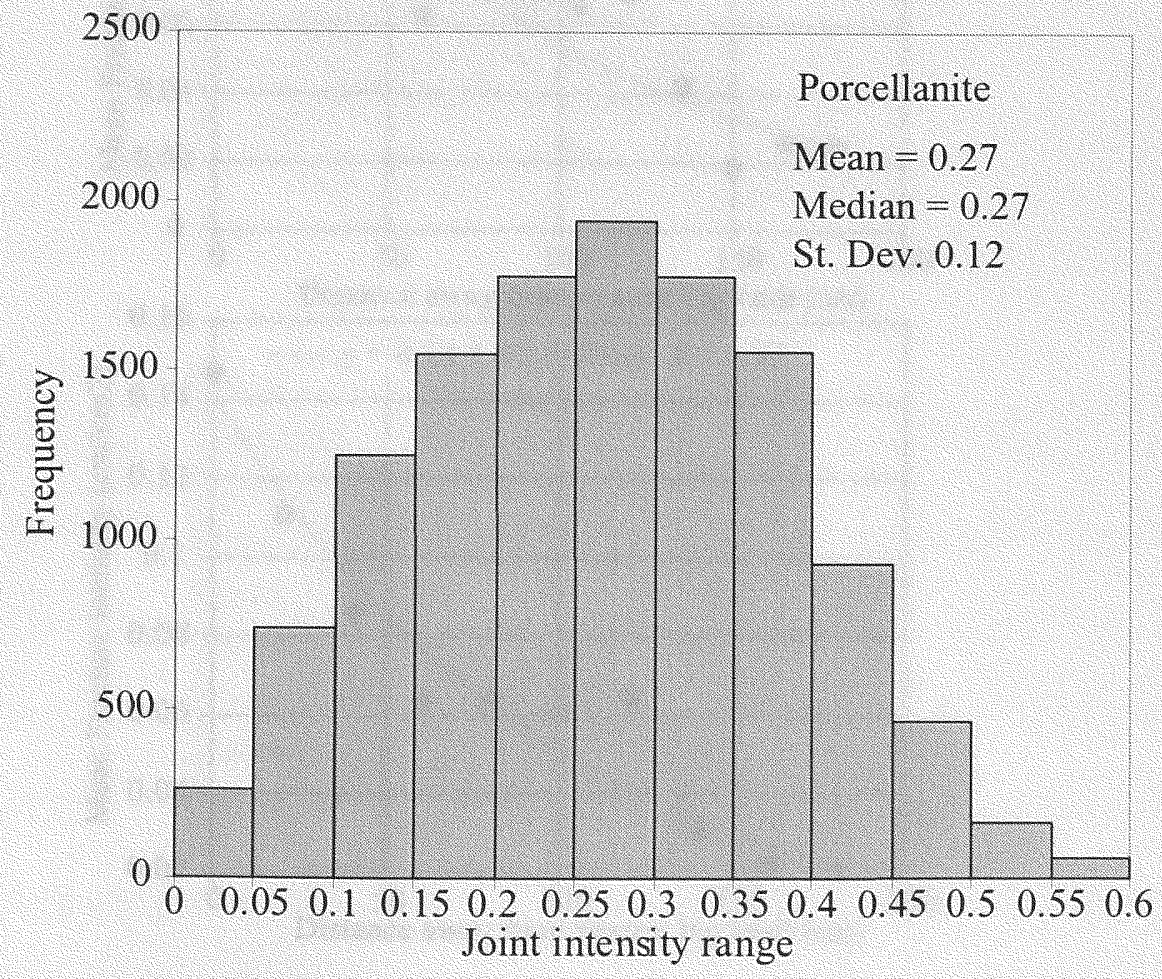

Fig. 4.19 Fracture intensity histograms for Section 2 (a) small faults in mudstones and (b) joints in porcellanites. 
(a)

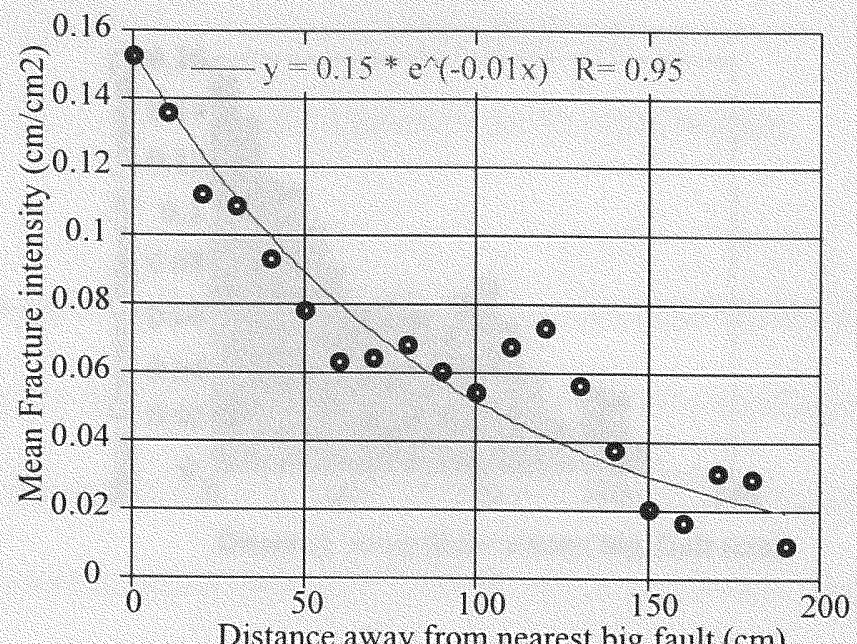

(b)

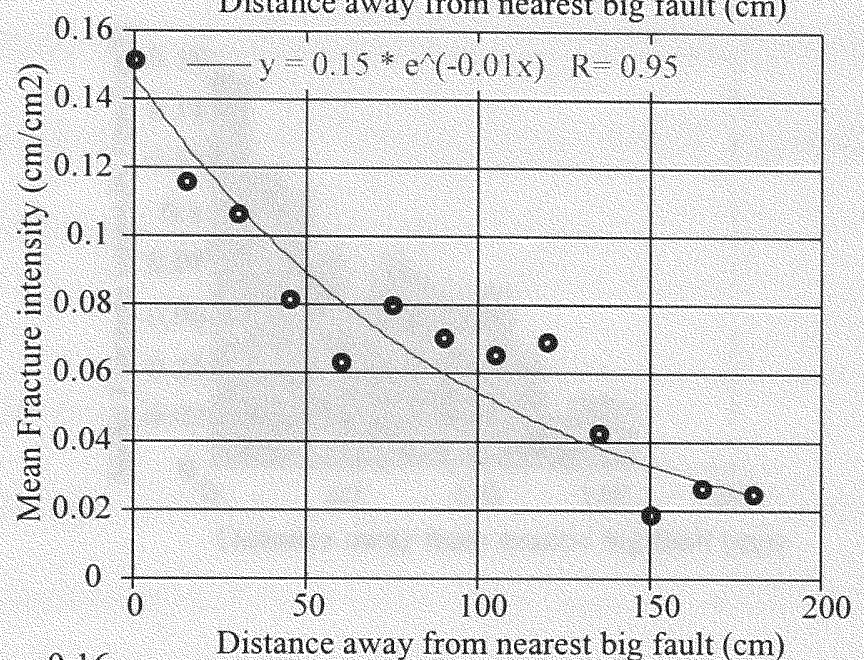

(c)

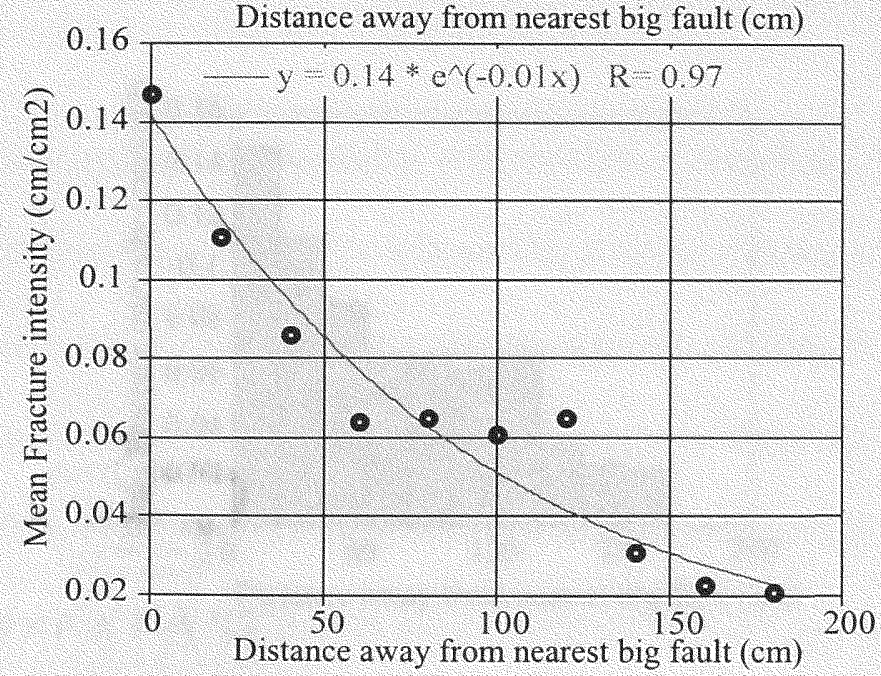

Fig. 4.20 Plots of average fracture intensity as a function of distance from nearest big fault in Section 2. Buffer sizes are (a) $10 \mathrm{~cm}$ (b) $15 \mathrm{~cm}$ (c) $20 \mathrm{~cm}$. See text for more details. 
(a)

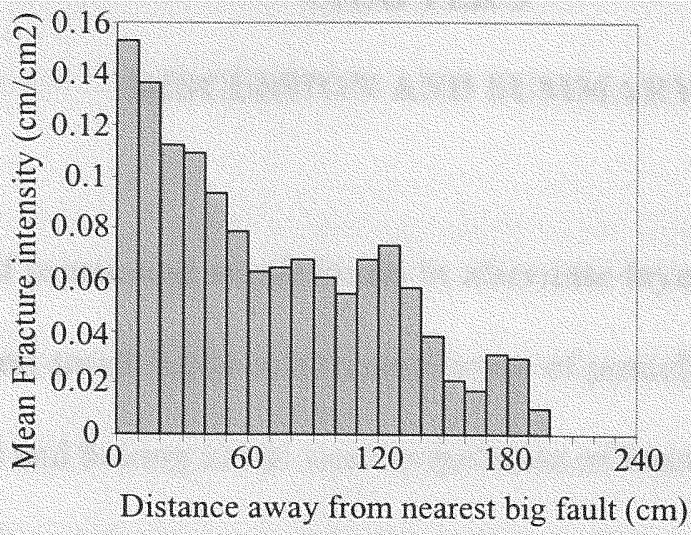

(b)

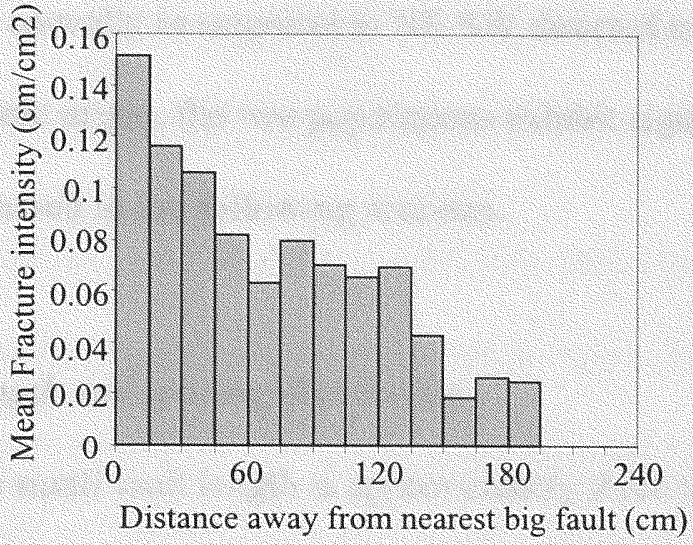

(c)

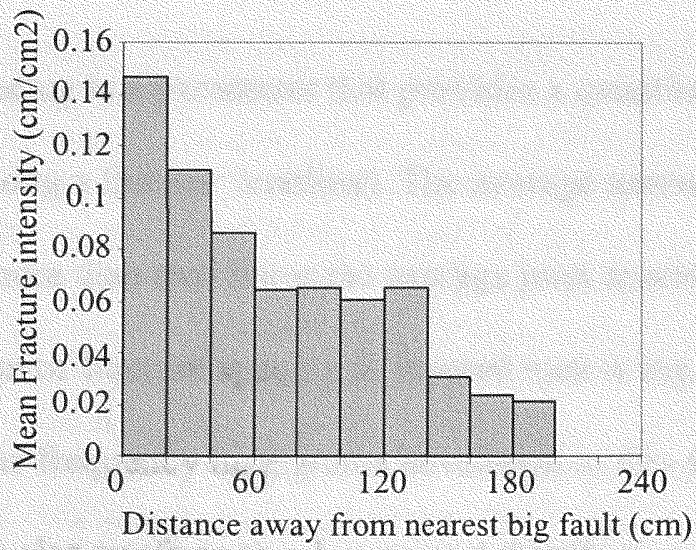

Fig. 4.21 Histogram frequency plots of average fracture intensity as a function of distance from nearest big fault in Section 2. Buffer sizes are (a) $10 \mathrm{~cm}$ (b) $15 \mathrm{~cm}$ (c) $20 \mathrm{~cm}$. 


\section{CHAPTER 5}

\section{DISCUSSION AND SUMMARY}

\subsection{Comparison of joints and small faults in alternate layers of Section 1}

The joints and small faults in alternate layers of porcellanite and mudstone units share similar trends and belong to the same population of fractures measured by Gross and Engelder (1995) and Gross et al. (1997b) at Arroyo Burro. These two different types of fractures formed coevally in response to NE-SW directed tectonic shortening. Despite their common tectonic origin, the two populations exhibit significant parametric differences, as discussed in the following sections.

\subsubsection{Fracture length and spacing distribution}

The average small fault length is approximately three times that of the mean joint length. Small fault lengths show a much wider range of variability than joint lengths (Fig. 4.1).

Fracture spacing is a parameter that provides a quantitative description of fracture trace distribution along a line (or scanline). The average spacing of small faults in mudstone units is more than two times the average joint spacing in porcellanite units. A common distribution of fracture spacing in layered rock is log-normal (Huang and Angelier, 1989). The frequency histograms developed in this study, of both joint and small fault spacings also conform to a log normal distribution, except for bed number 15 (jointed porcellanite unit) where the distribution is normal (Figs. 4.2, 4.3). Summary 
statistics calculated for joint and fault spacing measurements from the centrally positioned scanlines are presented in Table 5.1.

Table 5.1. Summary table of fracture spacing statistics for jointed and faulted units at Section 1.

\begin{tabular}{ccc}
\hline $\begin{array}{c}\text { Rock type } \\
\text { Fracture type }\end{array}$ & $\begin{array}{c}\text { Porcellanite } \\
\text { Joints }\end{array}$ & $\begin{array}{c}\text { Mudstone } \\
\text { Faults }\end{array}$ \\
\hline Mean (cm) & 2 & 4.9 \\
Median (cm) & 1.7 & 4.0 \\
St. Dev. & 1.2 & 4.4 \\
Skewness & 1.7 & 2.3 \\
Kurtosis & 4.0 & 7.2 \\
N & 329 & 85 \\
\hline
\end{tabular}

The coefficient of variation $(\mathrm{Cv})$ is calculated from the fracture spacing statistics. It is a parameter used to quantify the degree of clustering of fractures along a line (Cox and Lewis, 1966; and Gillespie et al., 1999). The coefficient of variation shows the variation of a variable around its mean. It is a scale independent means of comparing two different populations. The value of the coefficient of variation ranges from zero to infinity. A fracture spacing distribution with a standard deviation of zero corresponds to a population of equally spaced fractures, where the coefficient of variation is zero. On the other hand, where the standard deviation is equal to the mean, the coefficient of variation is 1 , indicating that the spacing is random. Gillespie et al. (1999), proposed an index for comparing fracture clustering based on the coefficient of variation. A clustered set of fractures has $\mathrm{Cv}>1$, while anti-clustered (more regularly spaced) fractures have $\mathrm{Cv}<1$. The results (Table 5.2, 5.3) show that the spacing distribution for both joints and faults fall within the range of the anti-clustered classification, but the coefficient of variation for 
small faults is $50 \%$ greater than that for joints. Thus the joints at Arroyo Burro are more regularly spaced than the small faults.

The statistical significance of the results are determined by comparing the results of this study with the confidence limits for the coefficient of variation calculated by Gillespie (2003) (Fig. 5.1). According to Gillespie (2003), if the coefficient of variation of the sample is greater than the value of the $95^{\text {th }}$ percentile then the sample is significantly more clustered than a random sample. On the other hand, if the coefficient of variation is less than the value of the $5^{\text {th }}$ percentile then the sample is significantly more anticlustered than a random sample. The coefficient of variation of joints (calculated from 807 samples) is less than the value of the $5^{\text {th }}$ percentile indicating that the joint population is significantly anticlustered, whereas the coefficient of variation of small faults ( $=0.9$ calculated from 191 samples) is more likely to be within the zone of random distribution.

Table 5.2. Summary values for the coefficient of variation calculated from scanlines in porcellanite units.

\begin{tabular}{ccc}
\hline Layer \# & Cv & Total \# of data \\
\hline & & \\
\hline 8 & 0.699 & 160 \\
9 & 0.695 & 189 \\
11 & 0.628 & 192 \\
13 & 0.491 & 274 \\
15 & 0.511 & 128 \\
\hline Average & $\mathbf{0 . 6 0 5}$ & $\mathbf{9 4 3}$ \\
\hline
\end{tabular}




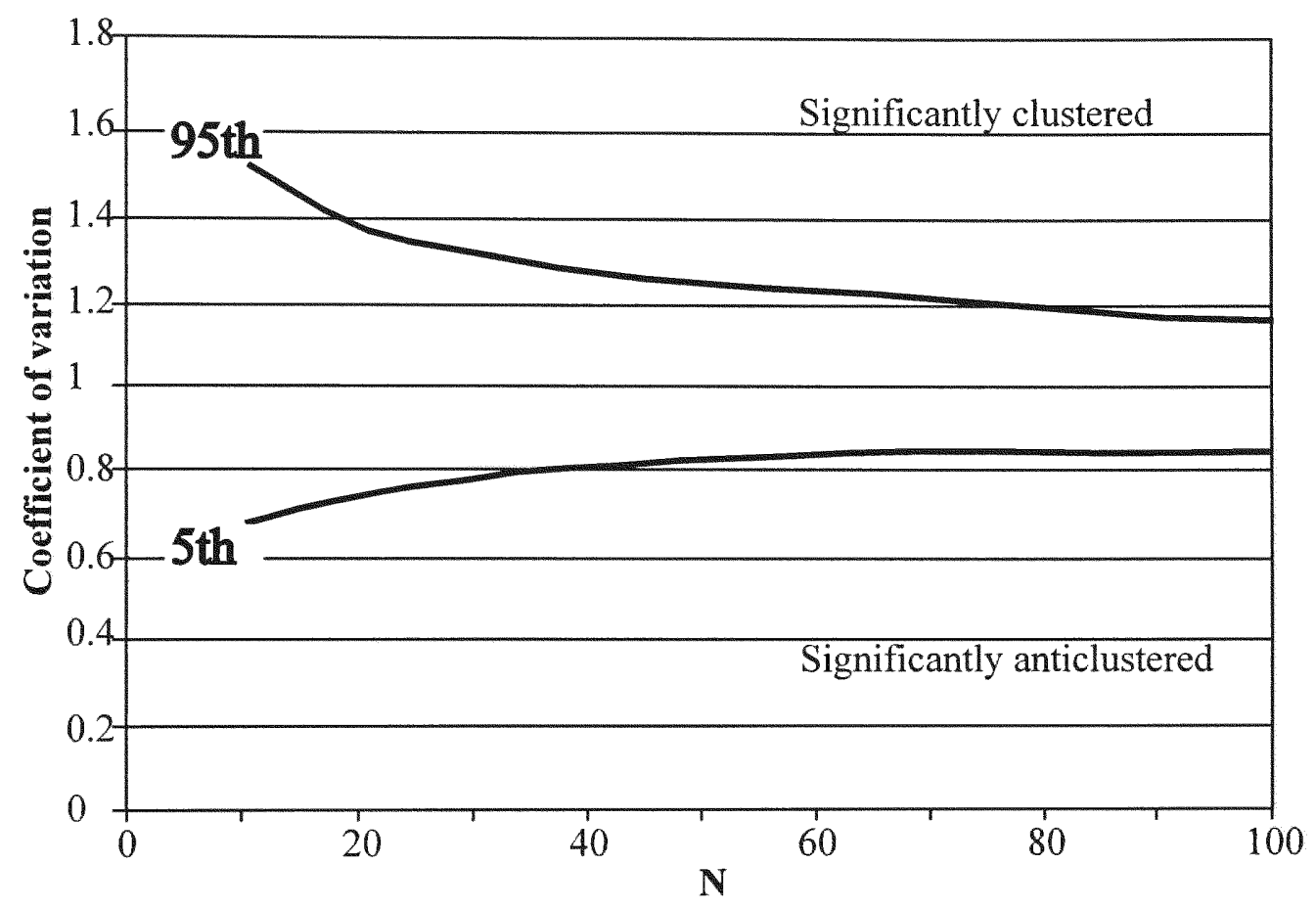

Fig. 5.1 Confidence intervals for the coefficient of variation for different number of fractures, $\mathrm{N}$, calculated from the 5 th and 95 th percentiles of a Monte Carlo simulation. Samples falling outside the confidence intervals are clustered or anticlustered at the $95 \%$ confidence interval (Gillespie, 2003). 
Table 5.3 Summary values for the coefficient of variation calculated from small fault scanlines in mudstone units.

\begin{tabular}{ccc}
\hline Layer \# & Cv & Total \# of data \\
\hline & & \\
\hline 7 & 0.678 & 39 \\
10 & 0.983 & 67 \\
12 & 0.988 & 58 \\
14 & 0.945 & 65 \\
\hline Average & $\mathbf{0 . 8 9 9}$ & $\mathbf{2 2 9}$ \\
\hline
\end{tabular}

\subsubsection{Fracture intensity}

Fracture intensity is a two-dimensional approach of quantifying fracture spacing, proposed by Gross et al., (2000). The fracture intensity maps exhibit a wider range of variability for joints $(0-1.2 / \mathrm{cm})$ as compared to small faults $(0-0.06 / \mathrm{cm})$. The statistics extracted from the cells of the fracture intensity maps (Figs. $4.4,4.5$ ) reveal that the average joint intensity $(0.14 / \mathrm{cm})$ for the whole area is approximately $75 \%$ greater than the average small fault intensity $(0.08 / \mathrm{cm})$. The joint and the small fault intensities are extracted for the individual units (Table $5.4,5.5$ ), showing that the average joint intensity in porcellanite units is $60 \%$ greater than the overall bulk joint intensity for the entire study area. Similarly, the average small fault intensity in the mudstone unit is $33 \%$ greater than the bulk small fault intensity derived for the whole area. 
Table 5.4. Joint intensity statistics in porcellanite units.

\begin{tabular}{cccc}
\hline Laver \# & $\begin{array}{c}\text { Mean } \\
(\mathbf{c m})\end{array}$ & $\begin{array}{c}\text { Range } \\
(\mathbf{c m})\end{array}$ & $\begin{array}{c}\text { St.Dev. } \\
(\mathbf{c m})\end{array}$ \\
\hline & & & \\
\hline 8 & 0.335 & 1.067 & 0.210 \\
9 & 0.376 & 1.148 & 0.250 \\
11 & 0.425 & 1.044 & 0.213 \\
13 & 0.398 & 1.000 & 0.217 \\
15 & 0.213 & 1.003 & 0.192 \\
\hline Average & $\mathbf{0 . 3 4 9}$ & $\mathbf{1 . 0 5 2}$ & $\mathbf{0 . 2 1 6}$ \\
\hline
\end{tabular}

Table 5.5. Small fault intensity statistics in mudstone units.

\begin{tabular}{cccc}
\hline Laver \# & $\begin{array}{c}\text { Mean } \\
(\mathbf{c m})\end{array}$ & $\begin{array}{c}\text { Range } \\
(\mathbf{c m})\end{array}$ & $\begin{array}{c}\text { St.Dev. } \\
(\mathbf{c m})\end{array}$ \\
\hline & & & \\
\hline 7 & 0.102 & 0.427 & 0.080 \\
10 & 0.126 & 0.528 & 0.104 \\
12 & 0.076 & 0.302 & 0.081 \\
14 & 0.111 & 0.431 & 0.091 \\
\hline Average & $\mathbf{0 . 1 0 4}$ & $\mathbf{0 . 4 2 2}$ & $\mathbf{0 . 0 8 9}$ \\
\hline
\end{tabular}

The visual inspection of the intensity maps reveals that the areas of high joint intensity and the areas of high small fault intensity are mostly exclusive of each other. The areas of high joint intensity follow linear trends that are approximately parallel to the porcellanite units and the areas of high fault intensity are parallel to the mudstone units. Map overlay analysis is performed with the joint intensity and small fault intensity maps (Fig. 5.2), using the technique explained in Chapter 3 . The joint intensity map is superimposed on the small fault intensity map, and a third map is generated (Fig. 5.3) that is classified in the following order:

a) Cells with joint intensity values greater than $0.1 / \mathrm{cm}$

b) Cells with fault intensity values greater than $0.1 / \mathrm{cm}$ 

c) Cells with both joint and fault intensity values greater than $0.1 / \mathrm{cm}$
d) Cells with both joint and fault intensity values less than $0.1 / \mathrm{cm}$.

The area occupied by different classes of cells is expressed as a percentage of total area (Fig. 5.4a). The results show that $39 \%$ of the total area is covered by class "a" (high joint intensity cells) and 34\% is covered by class "b" (high small fault intensity cells) as opposed to only $6 \%$ covered by class "c" (high joint or small fault intensity). The results are presented in the form of a histogram (Fig. 5.4b). The results show very clearly the effects of mechanical stratigraphy on fracture style, whereby faults and joints develop coevally in adjacent lithologies. The stratigraphic control on fracture development is manifested by only $6 \%$ overlap of fracture types in the section. These encouraging results suggest that GIS can provide a rigorous quantitative means to evaluate fracture partitioning in layered rocks.

\subsubsection{Fractal dimension}

Fractal dimension (D) is an indicator of degree of complexity or homogeneity. The value of $\mathrm{D}$ for a 2-dimensional fracture network varies between 1 and 2 . The fractal dimension of 2 indicates a perfectly homogeneous distribution (Babadagli, 2001). Thus D value less than 2 for both joints and faults suggest that the distribution of both the populations are heterogeneous. The fractal dimensions calculated from the small faults and joints exhibit an $18 \%$ difference in D values, which is higher than the $6 \%$ difference required to indicate a significant dissimilarity in distribution (Barton et al., 1991; Ehlen, 1999). The lower $D$ value for faults indicates that faults are more irregularly spaced than joints. A low fractal dimension is also indicative of increased clustering (Velde, 1990; 
量

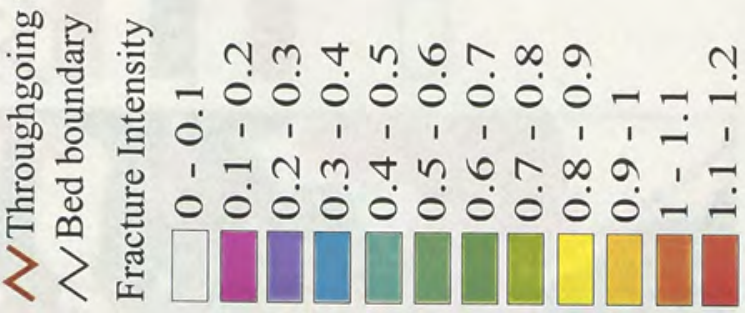

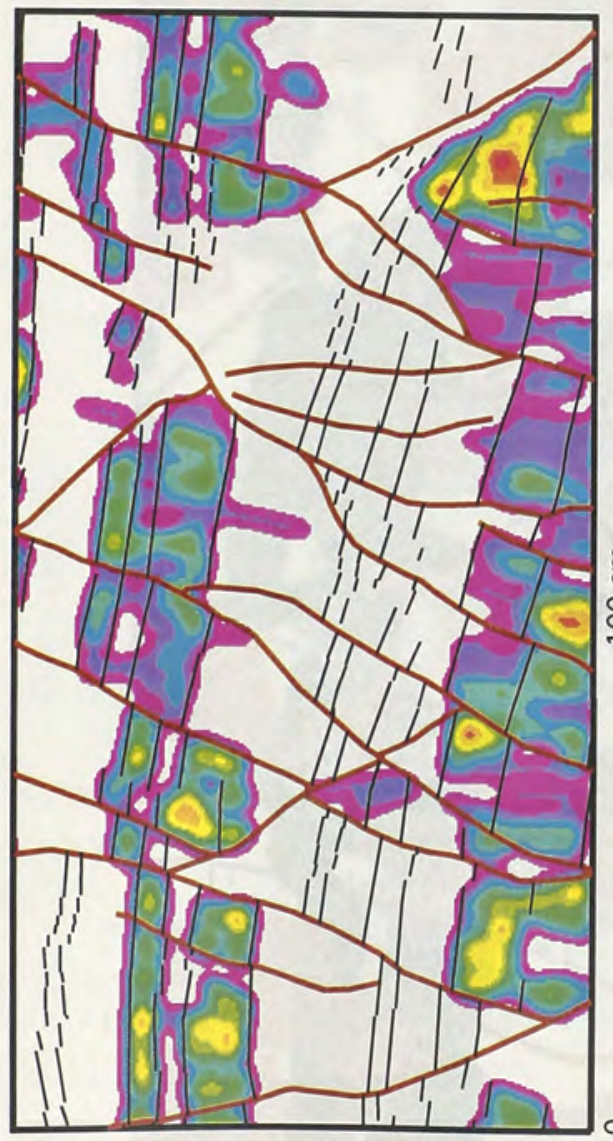

(త)

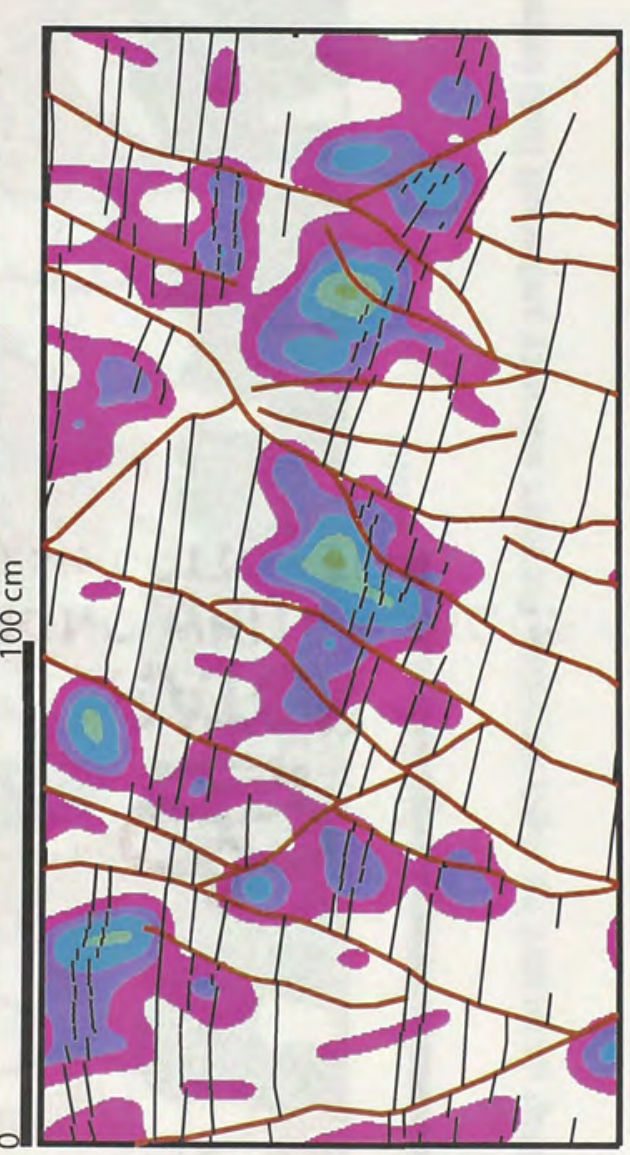

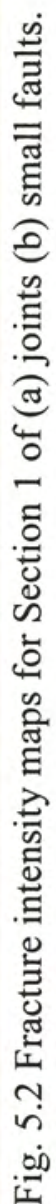

은 


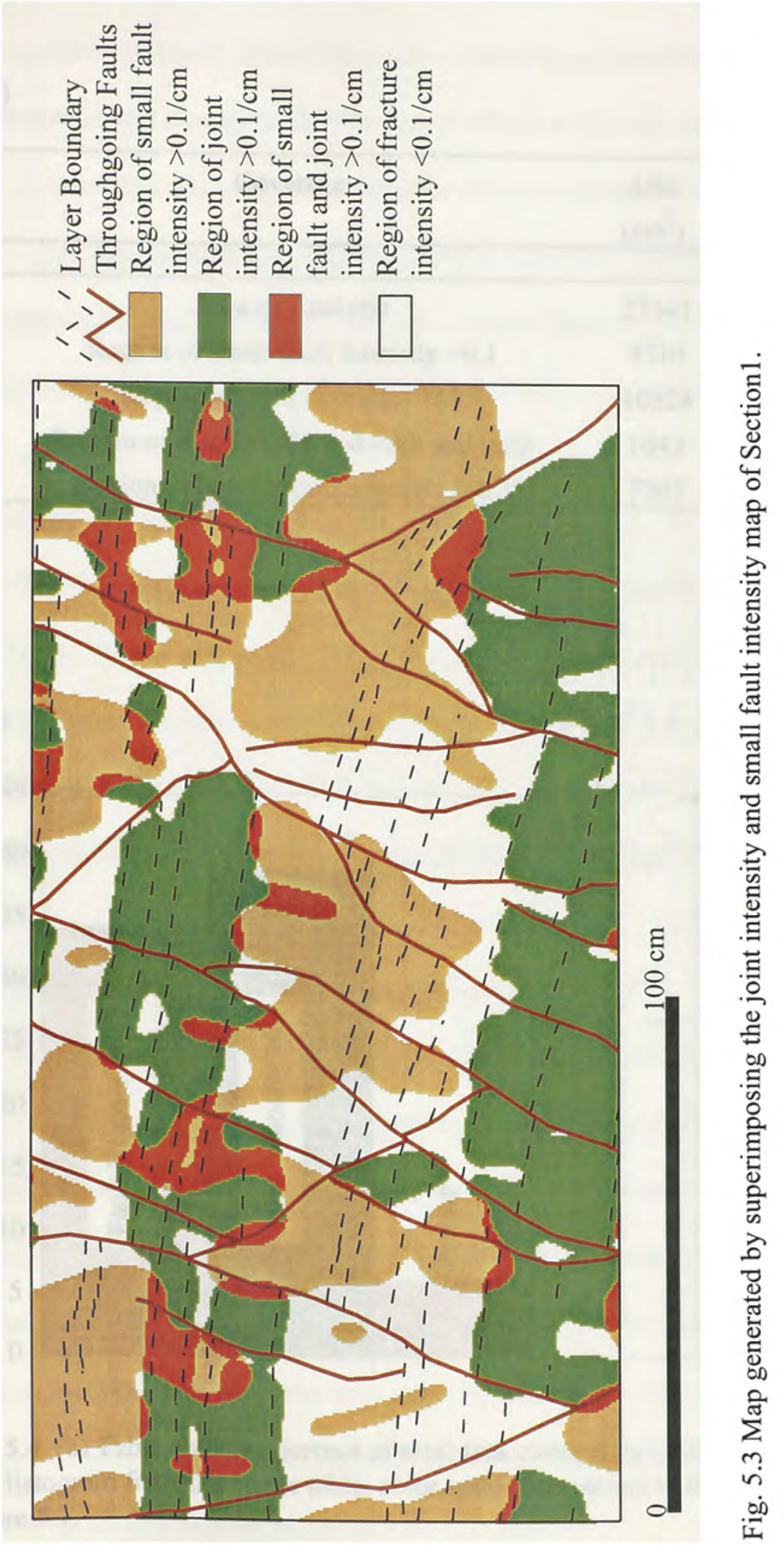


(a)

\begin{tabular}{ccc}
\hline Coverage & $\begin{array}{c}\text { Area } \\
\left(\mathrm{cm}^{2}\right)\end{array}$ & $\begin{array}{c}\text { Percentage } \\
\%\end{array}$ \\
\hline Area of Analysis & 27141 & \\
Region of small fault intensity $>0.1$ & 9310 & 34 \\
Region of joint intensity $>0.1$ & 10524 & 39 \\
Region of overlap of small fault and joint & 1643 & 6 \\
Region of low fracture intensity $(<0.1)$ & 7307 & 27 \\
\hline
\end{tabular}

(b)

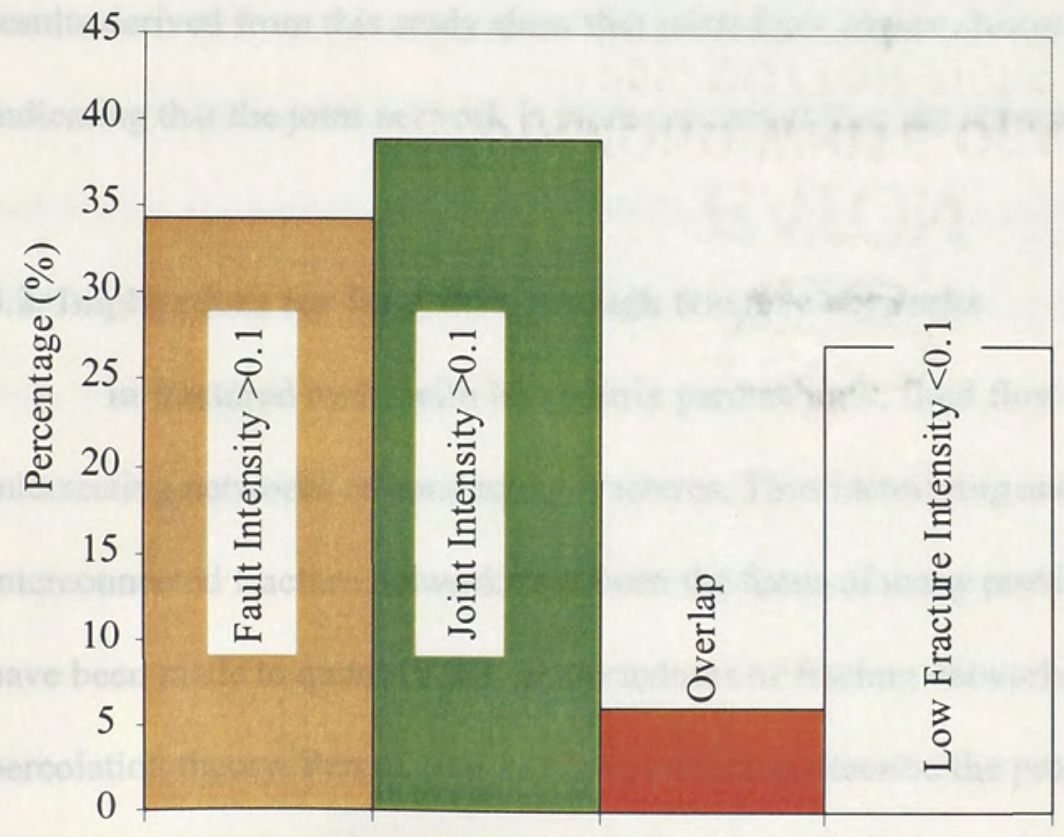

Fig. 5.4 (a) Table showing percent of total area covered by each fracture type. (b) Histogram from the above table, color codes correspond to the map of Figure 5.1. 
Manning, 1994; Belfield, 1998). Thus, a low fractal dimension for small faults (as compared to joints) conforms with the results obtained from the coefficient of variation.

Fractal dimension is also an indicator of the connectivity of a fracture pattern, with a higher fractal dimension corresponding to increased connectivity (Barton, 1995). This suggests that the joint population with a fractal dimension of 1.48 is capable of forming a more connected network than the population of small faults $(D=1.27)$.

\subsubsection{Fracture connectivity}

The ability of a fracture system to transmit fluids depends on the fracture network connectivity. The cluster size is a parameter that indicates the degree of connectivity of a fracture network; the higher the cluster size, the higher will be the connectivity. The results derived from this study show that joints have higher cluster sizes than small faults, indicating that the joint network is more connected than the network of small faults.

\subsection{Implications for fluid flow through fracture networks}

In fractured rocks with low matrix permeability, fluid flow is regulated by intersecting networks of conducting fractures. Thus identifying and characterizing interconnected fracture networks has been the focus of many previous studies. Attempts have been made to quantify the connectedness of fracture networks using concepts of

percolation theory. Percolation is a term coined to describe the property of a system of conductors, which emerges at the onset of macroscopic connectivity within the system (Berkowitz, 1995). A simple percolation model is composed of sites on a regular Euclidean space that may be occupied with a probability $p$ or unoccupied with a 
probability (1-p) (Bebbington et al. 1990) (Fig.5.5). In a 2 dimensional fracture network, the sites are represented by fracture-intersection-points. For any finite lattice system, there is a critical value of $p$, above which the bonds extend to connect the opposite faces of the lattice. This critical value of $p$ is called the percolation threshold. In terms of fracture networks the percolation threshold signifies a value above which the fracture cluster will be large enough to form a backbone.

Barton (1995) suggested that fracture systems with higher fractal dimensions (D) are likely to be more connected. Further he suggested the percolation threshold of a fracture system is reached with fractal dimensions greater than 1.35. This indicates that the joint system $(\mathrm{D}=1.48)$ in the present study should be able to form a backbone. But the analyses show that the joints are not capable of forming a backbone by themselves. This is probably due to the fact that the box counting method of calculating fractal dimension does not account for the fracture orientation, which is an important parameter that affects connectivity (Zhang and Sanderson, 1995). In this study the joints are dominantly oriented in one direction, which makes the network pattern less connected even with a high fractal dimension.

Odling (1997) suggested a threshold value of cluster size $=0.5$, above which the fracture cluster will be percolating. In other words, a fracture network with a cluster size higher than 0.5 is capable of forming a fracture backbone that can establish a continuous pathway for fluid flow. The results from the present study show that only the large fault cluster (cluster size $=0.8)$ and the cluster composed of all the fractures (cluster size $=$ 0.7 ), yielded a cluster size greater than the threshold and the clusters span to connect the 


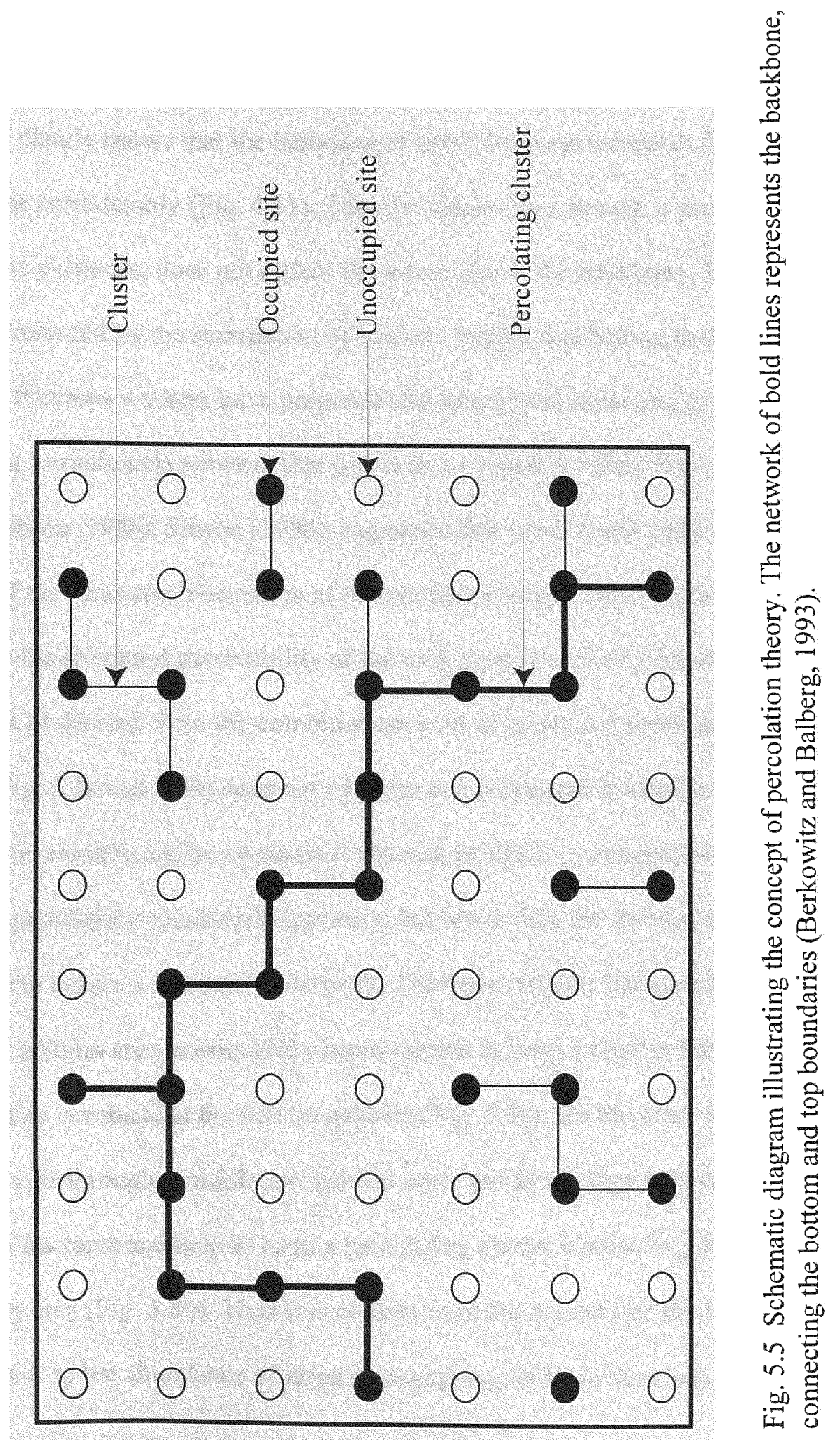


opposite ends of the study area. The cluster size values indicate that the cluster composed of all fractures is smaller than that of the big-fault cluster, though the visual inspection of the map clearly shows that the inclusion of small fractures increases the size of the backbone considerably (Fig. 4.11). Thus the cluster size, though a good indicator of backbone existence, does not reflect the actual size of the backbone. The backbone size is well represented by the summation of fracture lengths that belong to the backbone.

Previous workers have proposed that interlinked shear and extension fractures can form a continuous network that serves as a conduit for fluid flow (Fig. 5.6a) (Hill, 1977; Sibson, 1996). Sibson (1996), suggested that small faults and joints in alternate layers of the Monterey Formation at Arroyo Burro form a fault-fracture mesh that can enhance the structural permeability of the rock mass (Fig. 5.6b). However, the cluster size of 0.24 derived from the combined network of joints and small faults reported in this study (Fig. 5.7a and 5.7b) does not conform to a connected fracture network. The cluster size of the combined joint-small fault network is higher in comparison to cluster sizes for the two populations measured separately, but lower than the threshold value of 0.5 required to ensure a continuous network. The bed-confined fractures in alternate layers of the rock column are occasionally interconnected to form a cluster, but more commonly the clusters terminate at the bed boundaries (Fig. 5.8a). On the other hand, the large faults that traverse through multiple mechanical units, act as a bridge between isolated clusters of small fractures and help to form a percolating cluster connecting the opposite ends of the study area (Fig. 5.8b). Thus it is evident from the results that the fracture connectivity is sensitive to the abundance of large throughgoing faults in the study area. 
(a)

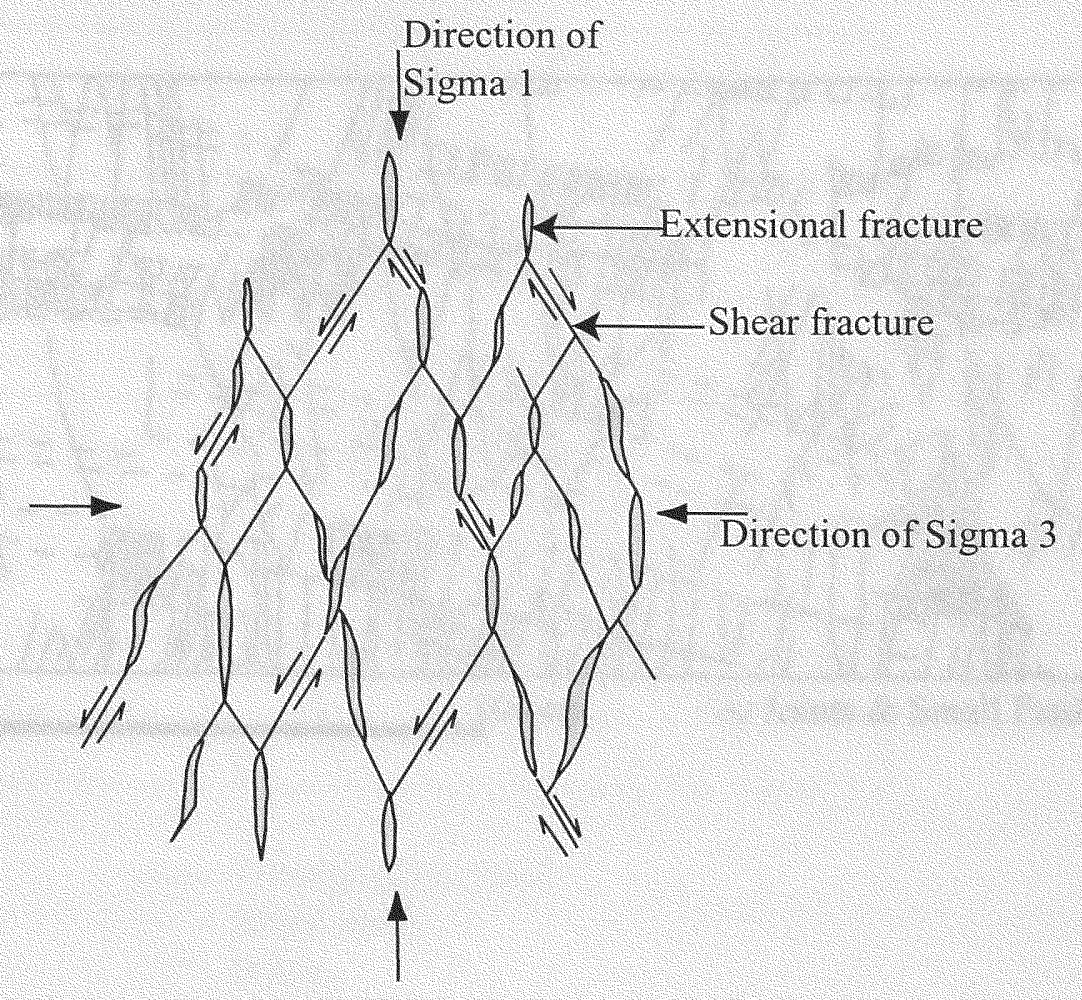

(b)

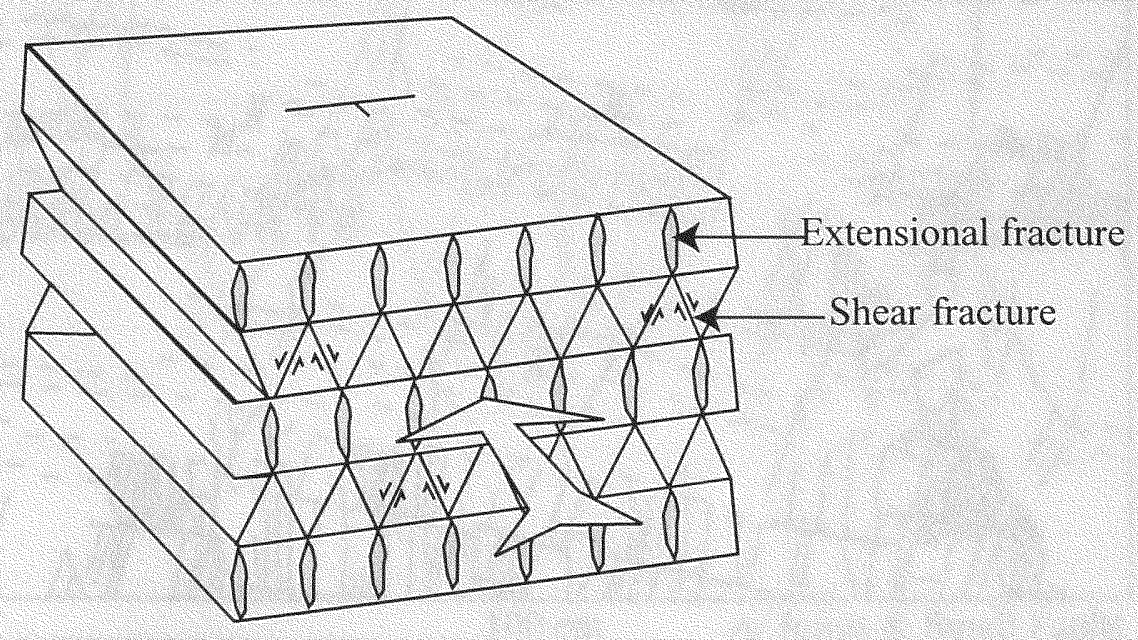

Fig. 5.6 (a) Schematic diagram illustrating mesh model of interlinked shear and extensional fractures (Hill, 1977). (b) Schematic diagram illustrating fault fracture mesh in alternate layers of competent and incompetent strata. The arrow indicates direction of fluid flow (Sibson 1996). 
(a)

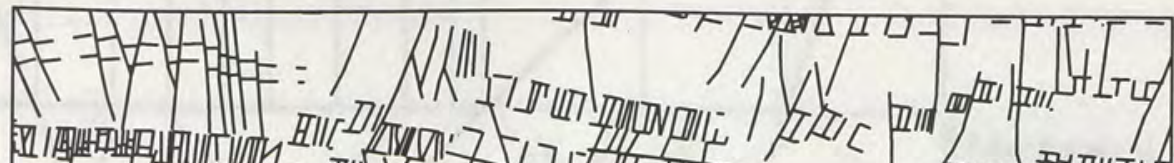

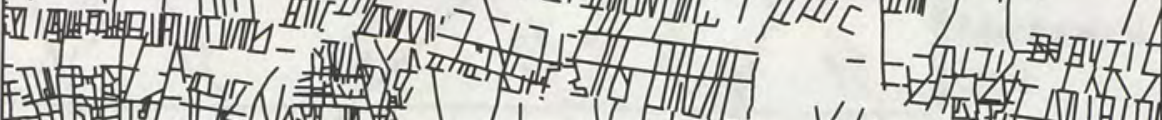

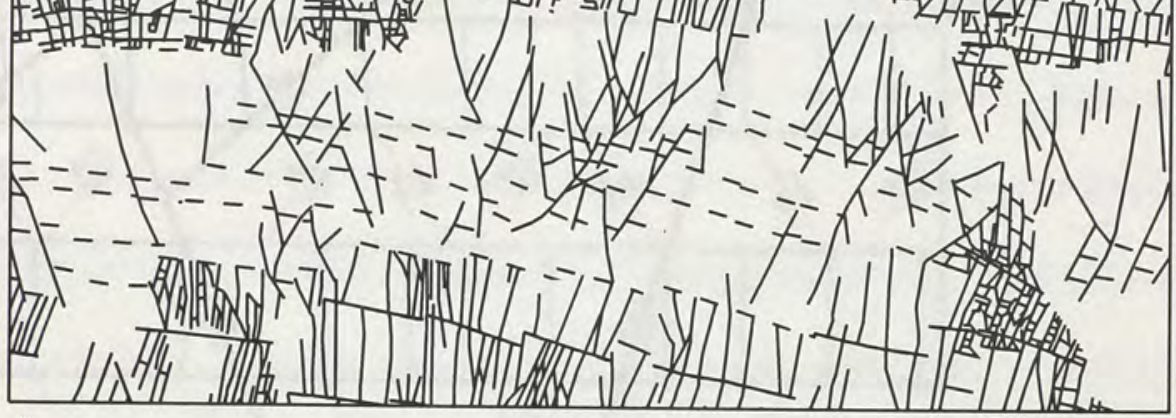

$0 \quad 100 \mathrm{~cm} \quad \sim$ Joints \& Small Faults

(b)

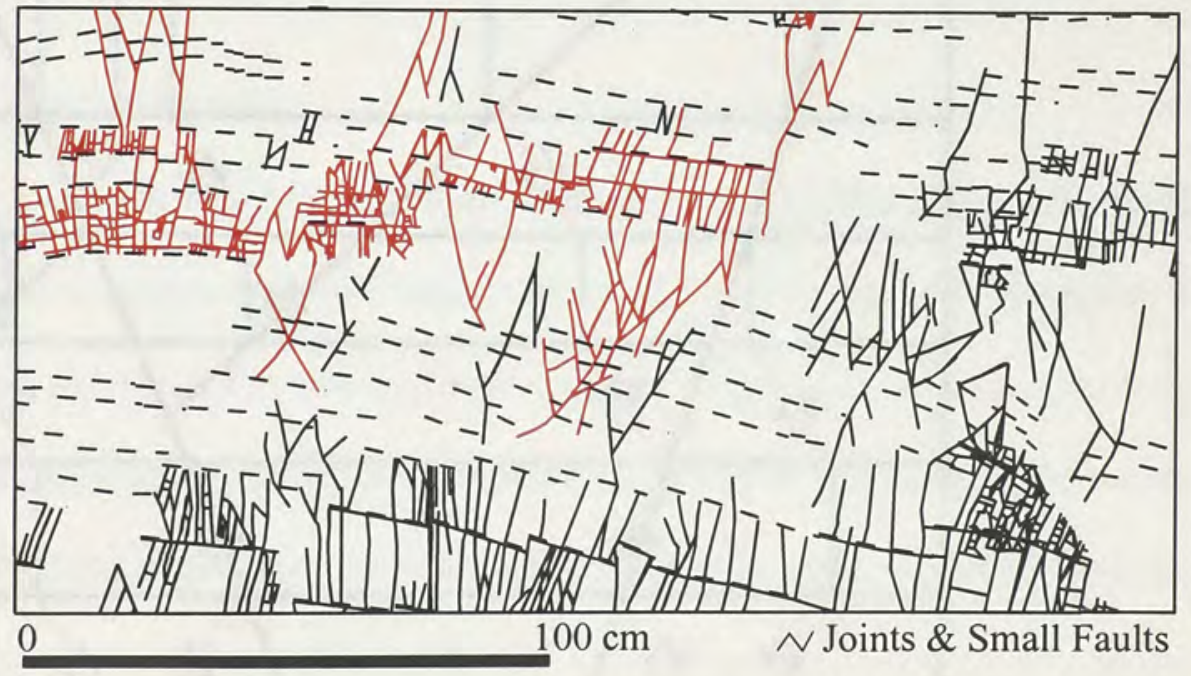

Fig. 5.7 (a) Bed confined fracture map of Section 1 (b) Fracture cluster maps for Section 1 for joints and small faults together, fractures belonging to the largest cluster is indicated by red color. 


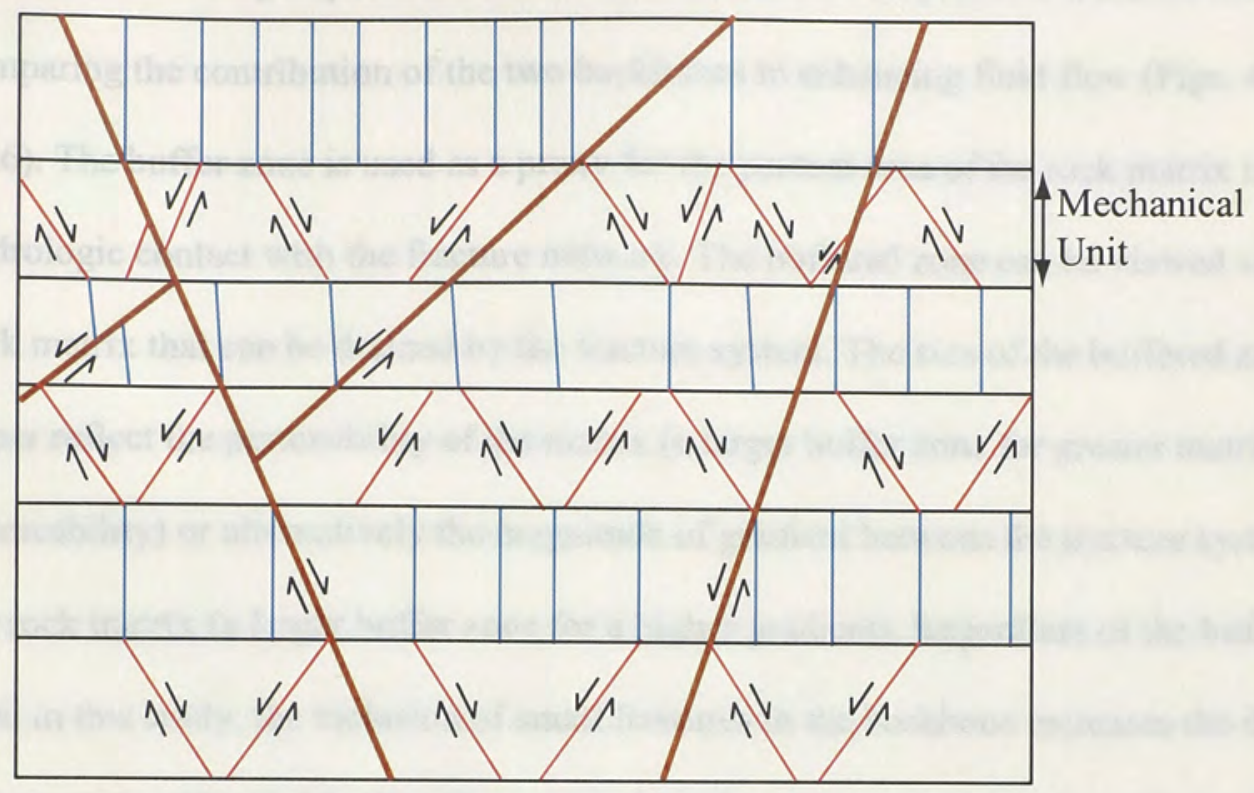

— Throughgoing faults

_ Small faults

- Joints

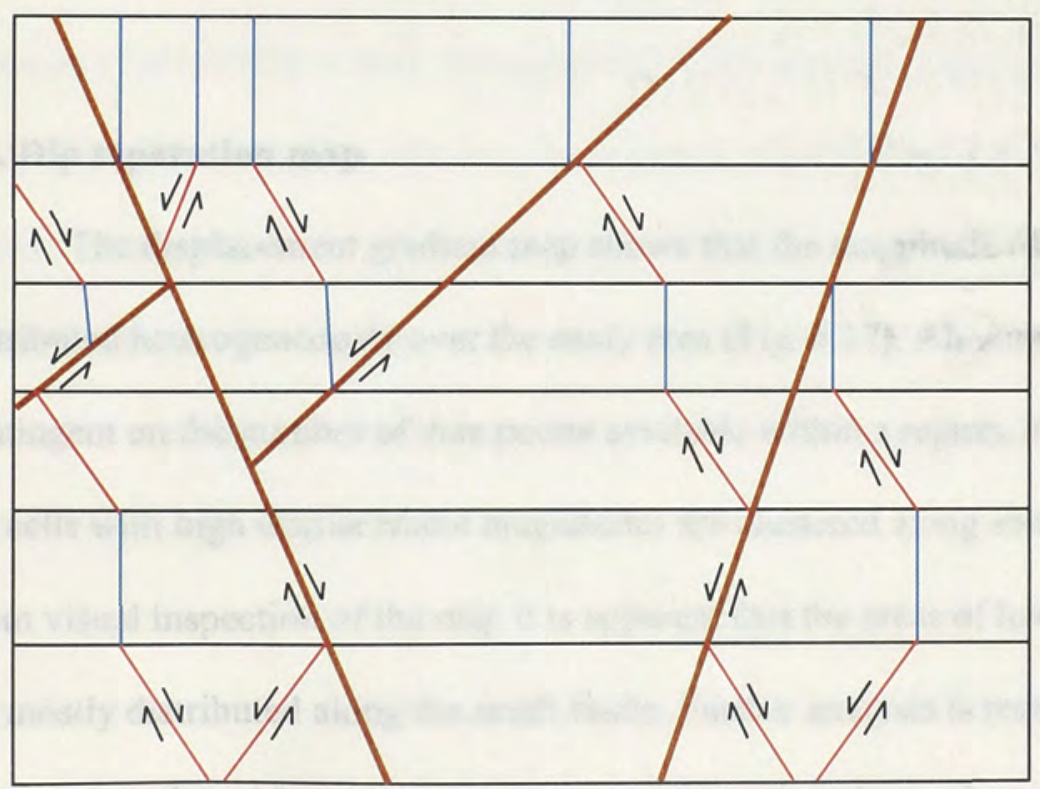

Fig. 5.8 (a) Fracture map composed of throughgoing faults and bed-confined fractures. (b) Fracture backbone generated from the fracture map of Figure 5.8 a. 
Buffer analysis performed on the fracture backbone provides a framework for comparing the contribution of the two backbones in enhancing fluid flow (Figs. 4.124.16). The buffer zone is used as a proxy for the percent area of the rock matrix in close hydrologic contact with the fracture network. The buffered zone can be viewed as the rock matrix that can be drained by the fracture system. The size of the buffered zone can either reflect the permeability of the matrix (a larger buffer zone for greater matrix permeability) or alternatively the magnitude of gradient between the fracture system and the rock matrix (a larger buffer zone for a higher gradient). Regardless of the buffer sizes used in this study, the inclusion of small fractures in the backbone increases the drainage area considerably (Table 4.3). Thus it can be inferred from these analyses that, while large faults are required to establish the backbone of a fracture network in layered rocks, the small fractures considerably increase the structural permeability of the rock.

\subsection{Dip separation map}

The displacement gradient map shows that the magnitude of fault displacement is distributed heterogeneously over the study area (Fig. 4.17). Although the results are contingent on the number of data points available within a region, it reflects nicely that the cells with high displacement magnitudes are clustered along some of the larger faults. From visual inspection of the map it is apparent that the areas of low displacement values are mostly distributed along the small faults. Further analysis is required to support the visual inspection. Also more study is required to select the method of interpolation that is suitable for analyzing this kind of dataset. 


\subsection{Fracture intensity as a function of proximity to large faults}

The effect of structural position on fracture distribution has been addressed by many previous workers to predict the control of folds (Narr, 1991; Lisle, 1994;

Masaferro, et al., 2003) and faults (Becker and Gross 1996; Gross et al., 1997a; Peacock, 2001) on the distribution of mesoscale fractures. Peacock (2001) studied joint intensity as a function of proximity to faults, to predict the temporal relation between the two fracture types. Becker and Gross (1996) examined the control of large throughgoing fractures on the development of small bed confined fractures, by comparing the fracture distribution within the fault zone, with the fracture distribution away from the fault zone. Gross et al. (1997a) established a relation between fault slip variation and joint intensity and suggested a model for local stain variation around fault zones.

In Section 2 the spatial relation between small fracture intensity is studied as a function of proximity to large throughgoing faults located in the central region of the study area. The analysis shows that the intensity of small fractures in the immediate vicinity of large faults is higher and decreases with increasing distance away from throughgoing faults. The plots of fracture intensity versus proximity to large faults reveal a negative exponential relation between the small fracture intensity and distance from big faults (Fig. 4.20).

As evident from Table 4.4 , the fracture intensity is considerably higher in the porcellanite units than in the mudstone units, so it is possible that the concentration of high values of fracture intensity within the fault zone is due to the porcellanite units exposed adjacent to the big faults. To factor out the influence of lithology on fracture intensity the buffer analysis was repeated excluding the fracture intensity values in the 
porcellanite units. The results from the analyses show a consistent decrease in fracture intensity with distance away from the big faults, although the correlation is not as strong (Figs. 5.9, 5.10). Thus it is evident from the results that the variation in fracture intensity correlates directly with proximity to the throughgoing faults.

The bed-confined fractures and the large faults in this section display similar trends, which indicates that all the fractures were formed in the same deformation phase. The spatial relation between small fractures and the large faults, may reflect the fact that all the fractures originated as small bed confined fractures. Clusters of small fractures may subsequently have coalesced into the larger faults. 
(a)

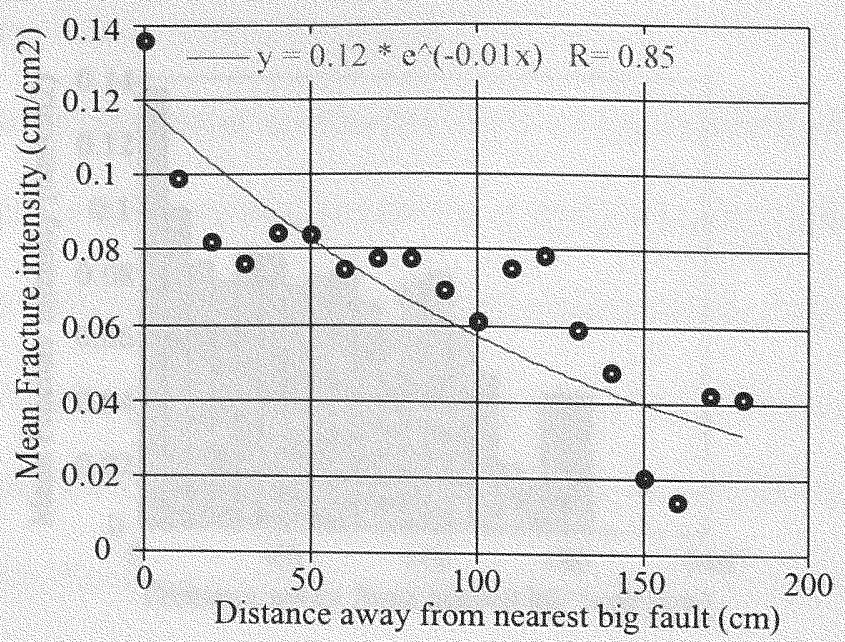

(b)

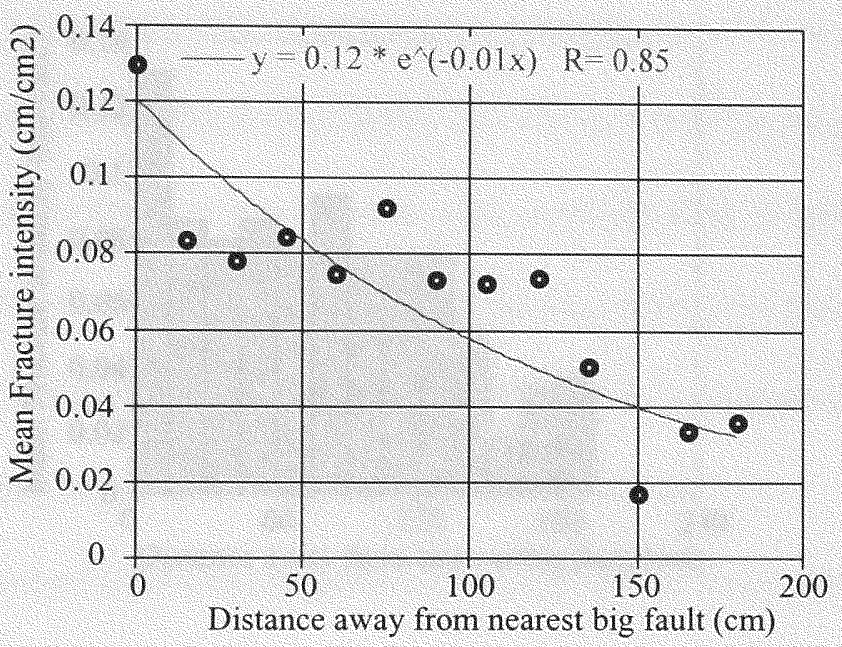

(c)

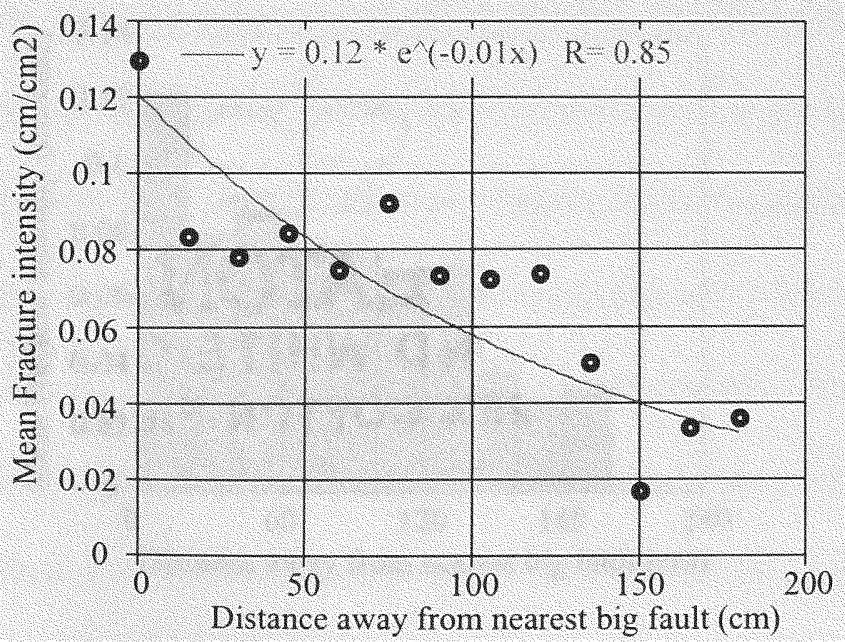

Fig. 5.9 Plots of average fracture intensity in the mudstone units (excluding porcellanite units) as a function of distance from nearest big fault in Section 2. Buffer sizes are (a) $10 \mathrm{~cm}$ (b) $15 \mathrm{~cm}$ (c) $20 \mathrm{~cm}$. 
(a)

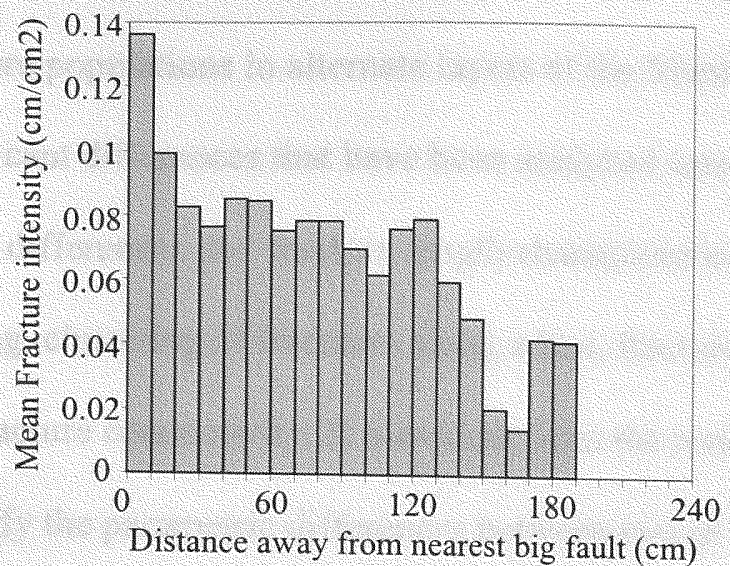

(b)

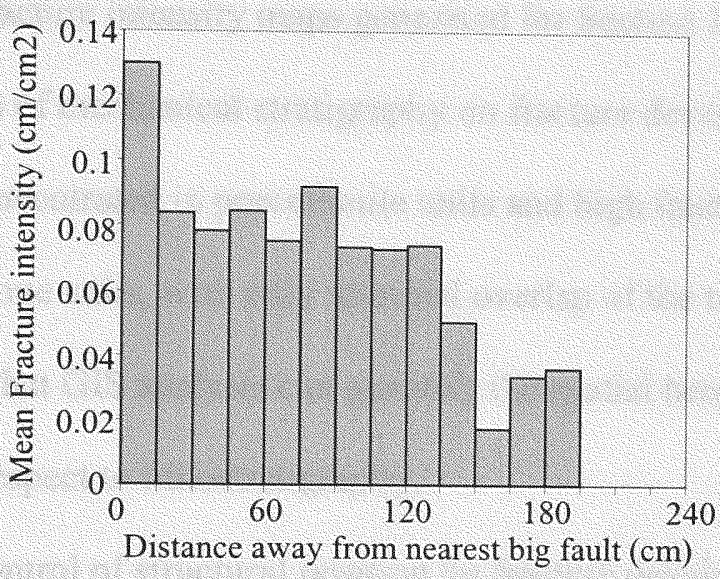

(c)

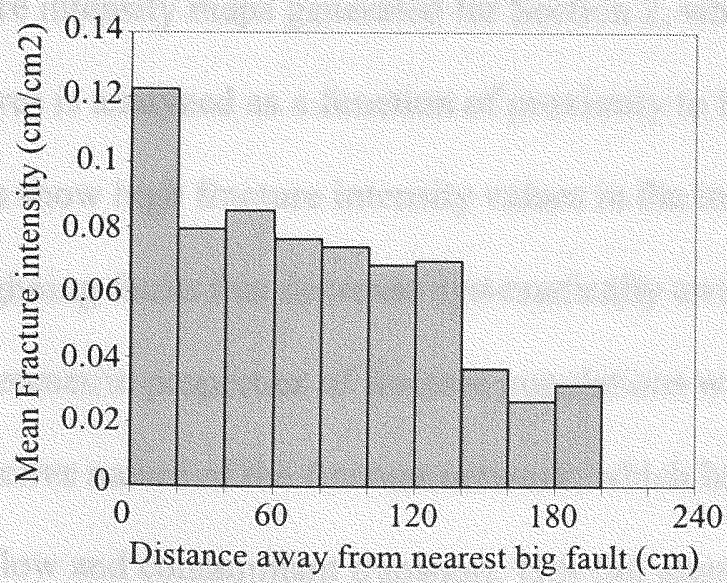

Fig. 5.10 Histogram frequency plots of average fracture intensity in mudstone units (excluding porcellanite units) as a function of distance from nearest big fault in Section 2. Buffer sizes are (a) $10 \mathrm{~cm}$ (b) $15 \mathrm{~cm}$ (c) $20 \mathrm{~cm}$. 


\subsection{Summary}

1. Fracture populations in alternate layers of the Monterey Formation exhibit significant differences that have been analyzed using GIS-based techniques. These differences are: fracture length characteristics, one dimensional fracture spacing, clustering of fractures along a line, fracture intensity, fractal dimension and fracture connectivity. It is evident from the results that GIS is an ideal tool to quantify the parametric differences between two or more fracture populations.

2. The fracture intensity maps generated for Section 1 demonstrate very strongly the effects of mechanical stratigraphy on fracture development. High joint intensities are concentrated in porcellanite units and high fault intensities are concentrated in mudstone units, with only minimal overlap of the two fracture types. Results show that GIS analysis can quantify the spatial heterogeneity of fracture systems with respect to lithostratigraphy.

3. The control of structural position on fracture development is demonstrated by the fracture intensity maps generated for Section 2, where the intensity of small fractures is analyzed as a function of proximity to large throughgoing faults. The results show high fracture intensity values in the immediate vicinity of the large throughoing faults that decrease systematically away from the fault zone.

4. The geometric properties of fracture populations were characterized to analyze the conductive nature of the fracture network, which has important implications for fluid flow and contaminant transport. GIS can identify fracture clusters and fracture backbones, important parameters that control the connectivity of fracture networks. The results show that the connectivity of a fracture network is sensitive 
to the abundance of large fractures in the study area as the large fractures increase the chances for a continuous pathway across the study area. On the other hand, small fractures dramatically increase the area of rock in contact with the fracture network, allowing for greater communication between the rock matrix and the fracture network. 


\section{REFERENCES}

Atwater, T., 1989, Plate tectonic history of the northeast Pacific and western North America, in Winterer, E.L, et al., eds., The Eastern Pacific Ocean and Hawaii: Boulder, Colorado, Geological Society of America, The Geology of North America, v. N, p.15-72.

Angelier, J., 1994, Fault slip analysis and paleostress reconstruction, in Hancock, P.L., ed., Continental deformation: Oxford, United Kingdom, Pergamon Prss, p.52-100.

Argus, D.F., and Gordon, R.G., 2001, Present tectonic motion across the Coast Ranges and San Andreas fault system in central California: Geologic Society of America Bulletin, v. 113, p. 1580-1592.

Babadagli, T., 2001, Fractal analysis of 2-D fracture networks of geothermal reservoirs in south-western Turkey: Journal of Volcanology and Geothermal Research, v. 112, p. 83-103.

Bahat, D., 1988, Early single-layer and late multi-layer joints in Lower Eocene chalks near Beer Sheva, Israel: Annales Tectonicae, v. 2, p. 3-11.

Bai, T., and Pollard, D.D., 2000 Fracture spacing in layered rocks: a new explanation based on the stress reduction: Journal of Structural Geology, v. 22, p. 43-57.

Barron, J.A., 1986, Updated diatom biostratigraphy for the Monterey Formation of California, in Casey, R.E., and Barron, J.A., eds., Siliceous microfossils and microplankton - Studies of the Monterey Formation and Modern Analogs: Pacific Section SEPM Special Publication, p.105-120.

Barton C.C., La Pointe, P.R., and Malinverno, A., 1991, Fractal and their use in the Earth Sciences: Short course manual, Geological Society of America Annual meeting, San Diego, CA.

Barton C.C., 1995, Fractal analysis of scaling and spatial clustering of fractures, in Barton, C.C., and La Pointe, P.R., eds., Fractals in the earth sciences: New York, New York, Plenum Press, p.141-178.

Bebbington, M., Vere-Jones, D., and Zheng, X., 1990, Percolation Theory; a model for rock fracture?: Geophysical Journal International, v. 100, p. 215-220.

Becker, A., and Gross, M.R., 1996 Mechanisms for joint saturation in mechanically layered rocks: An example from southern Israel: Tectonophysics, v. 257, p. 223-237. 
Behl, R.J., 1999, Since Bramlette (1946): The Miocene Monterey Formation of California revisited in Moores, E.M, et al. eds., Classic Cordielleran Concepts: View from California: Boulder, Colorado, Geological Society of America Special Paper 338, p. 301-313.

Belfield, W.C., Helwig, J., LaPointe, P., and Dahleen, W.K., 1983, South Ellwood oil field, Santa Barbara Channel California, a Monterey Formation fractured reservoir, in Isaacs, C.M., and Garrison, R.E., eds., Petroleum generation and occurrence of the Miocene Monterey Formation, California: Pacific Section of the Society of Economic Paleontologists and Mineralogists Special Publication, v. 17, p. 213-222.

Belfield, W.C., 1998, Incorporating spatial distribution into stochastic modeling of fractures: multi-fractals and Levy-stable statistics: Journal of Structural Geology, v. 20, p. $473-486$.

Berkowitz, B., and Balberg, I., 1993, Percolation Theory and Its Application to Groundwater Hydrology: Water Resources Research, v. 29, p. 775-794.

Berkowitz, B., 1995, Analysis of Fracture Network Connectivity Using Percolation Theory: Mathematical Geology, v. 27, p.467-483.

Bonham Carter, G. F., 1994, Geographic Information Systems for Geoscientists: Modelling with GIS: Oxford, United Kingdom, Pergamon Press, 398 p.p.

Brown, S.R., 1987, Fluid Flow Through Rock Joints; the effect of surface roughness: Journal of Geophysical Research, v. 92, p. 1337-1347.

Cande, S.C., Raymond C.A., Stock, J., and Haxby W.F., 1995, Geophysics of the Pitman fracture zone and Pacific-Antarctic plate motions during Cenozoic: Science, v. 270, p. $947-953$.

Chelidze, T. L., 1986, Percolation Theory as a Tool for Imitation of Fracture Process in Rocks: Pure and Applied Geophysics, v. 124, p. 731-748.

Clark, D.H., Hall, N.T., Hamilton, D.H., and Heck, R.G., 1991, Structural analysis of late Neogene deformation in the central off-shore Santa Maria Basin: Journal of Geophysical Research, v. 96, p. 6435-6458.

Clark, D.G., Slemmons, D.F., Caskey, S.J., and dePolo, D.M., 1994, Seismotectonic framework of coastal central California, in Alterman, I.B., et al., eds., Seismotectonics of the Central California Coast Ranges: Boulder, Colorado, Geological Society of America Special Paper, v. 292, p. 9-30.

Cox, D.R., and Lewis, P.A. W., 1966, The statistical analysis of series events: London, UK, Chapman and Hall, 285 p.p. 
Crouch, J.K., 1979, Neogene tectonic evolution of the California Continental borderland and western Transverse Ranges: Geological Society of America, v. 90, p. 338-345.

Dershowitz W.S., and Herda, H.H., 1992, Interpretation of fracture spacing and intensity in Tillerson, J.R., and Wawersik, W.R., eds., Proceedings of the $33^{\text {rd }}$ U.S Symposium on Rock Mechanics: Rotterdam, Balkema, p. 757-766.

Dibblee, T.W., 1982, Regional geology of the Transverse Ranges Province of southern California, in Fife, D.L. and Minch, J.A., eds., Geology and Mineral Wealth of the California Transverse Ranges: South Coast Geological Society Geuidebook, p.7-26.

Ehlen, J., 1999, Fracture characteristics in weathered granites: Geomorphology, v. 31, p. 29-45.

Ehlen, J., 2000, Fractal analysis of joint patterns in granite: International Journal of Rock Mechanics and Mining Sciences, v. 37, p. 909-922.

Eichhubl, P. and Boles, J.R., 1998, Vein formation in relation to burial diagenesis in the Miocene Monterey Formation, Arroyo Burro Beach, Santa Barbara, California, in Eichhbul, P. ed., Diagenesis Deformation and Fluid Flow in the Miocene Monterey Formation: Pacific Section, SEPM Special Publication, v. 83, p.15-36.

Eichhubl, P. and Boles, J.R., 2000, Focused fluid flow along faults in the Monterey Formation, coastal California: Geological Society of America, v. 112, p. 1667-1679.

Engelder, T., 1993, Stress regimes in the lithosphere: Princeton, New Jersey, Princeton University Press, 475 p.p.

Engelder, T., and Gross M.R., 1993, Curving joints and the lithospheric stress field in eastern North America: Geology, v. 21, p. 817-820.

Erdas, Inc., Erdas Imagine ${ }^{\circledR}$ Tour Guides, Version 8.6. Atlanta, GA: Erdas Inc., 2001.

ESRI, 1996, Using the Arc View spatial analysis: Redlands, CA, Environmental Systems Research Institute, Inc.

ESRI, 1997, GRID commands, ARC/INFO Version 7.12: Redlands, CA, Environmental Systems Research Institute, Inc.

Feder, J., 1988, Fractals: New York, New York, Plenum Press, 283 p.p.

Gillespie, P.A., Howard, C.B., Walsh, J .J., and Watterson, J., 1993, Measurement and characterization of spatial distributions of fractures: Tectonophysics, v.226, p.113-141. 
Gillespie, P.A., Johnston, J.D., Loriga, M.A., McCaffrey, K.L.W., Walsh, L.L., and Watterson, L., 1999, Influence of layering on vein systematics in line samples, in McCaffrey, K.J. W., et al., eds. Fractures fluid flow in and mineralization: Geological Society of London, Special Publication 155, p.35-56.

Gillespie, P.A., Walsh, J.J., Watterson, J., Bonson, C.G., and Manzocchi, T., 2001, Scaling relationships of joint and vein arrays from the Burren Co. Clare, Ireland: Journal of structural geology, v. 23, p. 183-201.

Gillespie, P. A., 2003, Comments on "The geometric and statistical evolution of normal fault systems: an experimental study of the effects of mechanical layer thickness on scaling laws" by R.V. Ackermann, R.W. Schlische and M. O. Withjack: Journal of Structural Geology, v. 25, p. 819-822.

Gross, M.R., 1993, The origin and spacing of cross joints: examples from the Monterey Formation, Santa Barbara Coastline, California: Journal of Structural geology, v. 15, p. 737-751.

Gross, M.R., and Engelder, T., 1995, Strain accommodated by brittle failure in adjacent units of the Monterey Formation, U.S.A.: Scale effects and evidence for uniform displacement boundary conditions: Journal of Structural geology, v. 17, p. 1303-1318

Gross, M.R., Fischer, M.P., Engelder, T., and Greenfield, R., 1995, Factor controlling joint spacing in interbedded sedimentary rocks: integrating numerical models with field observations from Monterey Formation, U.S.A., in Ameen, M.S. ed., Fractography: fracture topography as a tool in fracture mechanics and stress analysis: Geological Society Special Publication n. 2, p. 215-233.

Gross, M.R., 1995, Fracture partitioning: failure mode as a function of lihtology in the Monterey Formation of coastal California: Geological Society of America Bulletin, v. 107, p. 779-792.

Gross, M.R., Bahat, D., and Becker, A., 1997a, Relations between jointing and faulting based on fracture-spacing ratios and fault-slip profiles: A new method to estimate strain in layered rocks: Geology, v. 25, p. $887-890$.

Gross, M.R., Gutierrez-Alonso, G., Bai, T., Wacker, M.A., Collinsworth, K.B., and Behl, R.J., 1997b, Influence of mechanical stratigraphy and kinematics on fault scaling relations: Journal of Structural geology, v. 19, p. 171-183.

Gross, M.R., Finn, M.D., Whitman, D., and Ojeda, G. Y., 2000, Fracture density modeling using GIS: implications for the development of throughgoing fracture zones and subsurface fluid flow: American Association of Petroleum Geologists Annual Convention, v. 9, p. A60. 
Gueguen, Y., Chelidze, T., and Le Ravalec, M., 1997, Microstructures, Percolation Thresholds, and Rock Physical Properties: Tectonophysics, v. 279, p. 23-35.

Gutierrez-Alonso, G., and Gross, M.R., 1997, Geometry of inverted faults and related folds in the Monterey Formation: implications for the structural evolution of the southern Santa Maria basin, California: Journal of Structural geology, v. 19, p. 1303-1321.

Hennings, P.H., Olson, J.E., and Thompson, L.B., 2000, Combining outcrop data and three dimensional structural models to characterize fractured reservoirs: An example from Wyoming: American Association of Petroleum Geologists, v. 84, p. 830-849.

Hill, D.P., 1970, A model for earthquake swarms: Journal of Geophysical Research, v. 82, p. $347-352$,

Hornafius, J.S., 1985, Neogene tectonic rotation of the Santa Ynez Range, Western Transverse Ranges, California, suggested by paleomagnetic investigation of the Monterey Formation: Journal of Geophysical Research, v. 90, p. 12503-12522.

Hornafius, J.S., 1994, Field trip road to the Monterey Formation between Santa Barbara and Gaviota, California, in Hornafiu, J.S., ed., Field guide to the Monterey Formation between Santa Barbara and Gaviota, California: Pacific Section American Association of Petroleum Geologists, GB72, p.107-123.

Howell, D.G., Crouch, J.K., Greene, H.G., McCulloch, D.S., and Vedder, J.G., 1980, Basin development along the late Mesozoic and Cenozoic California margin: a plate tectonic margin of subduction, oblique subduciton and transform tectonics, in Balance, P.F., and Readin, H.G., eds., Sedimentation in Oblique-slip Mobile Zones: International Association of Sedimentologists Special Publication 4, p. 43-62.

Huang, Q., and Angelier, J., 1989, Fracture spacing and its relation to bed thickness: Geological Magazine, v. 126, p. 355-362.

Ingle, J.C., 1981, Cenozoic depositional history of the northern continental borderland of southern California and the origin of associated Miocene diatomites, in Issacs, C.M., ed., Guide to the Monterey Formation in the California coastal area, Ventura to San Luis Obispo: American Association of Petroleum Geologists, Pacific Section Field Guide, v. 52 , p. $9-24$.

Issacs, C.M., 1980, Diagenesis of the Monterey Formation examined laterally along the coast near Santa Barbara, California [Ph.D. dissertation]: Stanford, Stanford University, California, 329 p.p.

Issacs, C.M., 1981, Lithostratigraphy of the Monterey Formation, Goleta to Point Conception, Santa Barbara Coast, California, in Isaacs, C.M., ed., Guide to the Monterey 
Formation in the California coastal area, Ventura to San Luis Obispo: American Association of Petroleum Geologists, Pacific Section Field Guide, v. 52, p. 9-24

Issacs, C.M., 1983, Compositional variation sequence in the Miocene Monterey Formation, Santa Barbara coastal area, California, in Lame, D.K., and Steel, R.J., eds., Cenozoic Marine Sedimentation, Pacific Margin, USA: Pacific Section of the Society of Economic Paleontologists and Mineralogists Special Publication, p.117-132.

Isaacs, C.M., and Petersen, N.F., 1987, Petroleum in the Miocene Monterey Formation, California, in Hein, J.R., ed., Siliceous sedimentary rock-hosted ores and petroleum: New York, New York, Van Nostrand Reinhold Co., p. 83-116.

La Pointe, P.R., and Hudson, J.A., 1985, Characterization and interpretation of rock mass joint pattern: Geological Society of America, Special Paper 199. 37p.p.

La Pointe, P.R., 2002, Derivation of parent fracture population statistics from trace length measurements of fractal fracture populations: International Journal of Rock Mechanics and Mining Sciences, v. 39, p. 381-388.

Lawn, B.R., 1993, Fractures of brittle solids: Cambridge, New York, Cambridge University Press, 378 p.p.

Lisle, R.J., 1994, Detection of zones of abnormal strains using Gaussian curvature analysis: American Association of Petroleum Geologists Bulletin, v. 78, p. 1811-1819.

Long, J.C.S., and Witherspoon, P.A., 1985, The relationship of the degree of interconnection to permeability in fracture networks: Journal of geophysical research, 90(B), p. 3087-3098.

Luyendyk, B.P., Kamerling, M.J., and Terres, R., 1980, Geometric model for Neogene crustal rotations in southern California: Geological Society of America Bulletin, v. 91, p. 211-217.

Malinverno, A., 1995, Fractals and ocean floor topography: A review and a model, in Barton, C.C., and La Pointe, P.R., eds., Fractals in the earth sciences: New York, New York, Plenum Press, p.107-130.

Mandelbrot, B.B., 1967, How long is the coast of Britain? Statistical self-similarity and fractal dimension: Science, v. 156, p. 636-638.

Mandelbrot, B.B., 1983, The fractal geometry of nature: New York, New York, W.H. Freeman, 468 p.p.

Manning, C.E., 1994, Fractal clustering of metamorphic veins: Geology, v. 22, p. 335-338. 
Masaferro, J.L., Bulnes, M., Poblet, J., and Casson, N., 2003, Kinematic evolution and fracture prediction from 3-D seismic data, Salta province, northwest Argentina: American Association of Petroleum Geologists Bulletin, v. 87, p. 1083-1104.

Mauldon, M., and Dershowitz, W., 2000, A multi-dimensional system of fracture abundance measures: Geological Society of America Abstracts with Programs, v. 32, n. 7 , p. A474.

Mauldon, M., Dunne, W.M., Rohrbaugh, M.B., 2001, Circular scanlines and circular windows: new tools for characterizing the geometry of fracture traces: Journal of structural geology, v. 23, p. 247-258.

McIntosh, K.D., Reed, D.L., Silver, E.A., and Meltzer, A.S., 1991, Deep structure and structural inversion along the central California continental margin from EDGE seismic profile RU-3: Journal of Geophysical research, v. 96, p. 6459-6474.

McKinnon, T.C., 1989, Petroleum geology of the Monterey Formation in the Santa Maria and Santa Barbara Coastal offshore areas, in McKinnon, T.C., ed., Oil in the Monterey Formation: Washington, D.C., American Geophysical Union, $28^{\text {th }}$ International Geological Congress Field Trip Guidebook T311, p. 11-27.

McCulloch, D.S., 1989, Evolution of off-shore central California margin, in Winterer, E.L., et al., eds., The Esatern Pacific Ocean and Hawaii: Boulder, Colorado, Geological Society of America, The Geology of North America, v.N, p.439-470.

Namson, J., and Davis, T., 1990, Late Cenozoic fold and thrust belt of the southern Coast Ranges and Santa Maria Basin, California: American Association of Petroleum Geologists Bulletin, v. 74, p. 467-492.

Narr, W., 1991, Fracture density in the deep subsurface: Techniques with application to Point Arguello oil field: American Association Petroleum Geologists Bulletin, v. 75, p. $1300-1323$.

Narr, W., and Suppe, J., 1991, Joint spacing in sedimentary rocks: Journal of structural geology, v. 13, p. 1037-1048.

Nicholson, C., Sorlien, C.C., and Luyendyk, B.P., 1992, Deep crustal structure and tectonics in the off-shore Coast Ranges and Santa Maria Basin, California: American Association of Petroleum Geologists Bulletin, v. 20, p. 239-242.

Odling, N.E., 1995, The development of network properties in natural fracture patterns: an example from the Devonian sandtones of Western Norway in Proceedings, International ISRM Symposium on Fractured and Jointed Rock Masses: Lake Tahoe, California, A.A., Balkema, Rotterdam, p.35-41. 
Odling, N. E., 1997, Scaling and connectivity of joint systems in sandstones from western Norway: Journal of Structural Geology, v. 19, p. 1251-1271

Paulus, G., 2000, GIS-based analysis of fluid migration in sedimentary basins: Coburn, T.C., and Yarus, J.M., eds., Geographic information systems in petroleum exploration and development: Tulsa, American Association of Petroleum Geologists, p. 121-136.

Peacock, D.C.P., 2001, The temporal relationship between joints and faults: Journal of Structural Geology, v. 23, p. 329-341.

Peacock, D.C.P., Harris, S.D., and Mauldon, M., 2003, Use of curved scanlines and boreholes to predict fracture frequency: Journal of Structural Geology, v. 25, p. 109-119.

Pisciotto, K.A., and Garrison, R.E., 1981, Lithofacies and depositional environments of the Monterey Formation, California, in Garrison, R.E., et al., eds., The Monterey Formation and related siliceous rocks of California: Los Angeles, California, Pacific Section Society of Economic Paleontologists and Mineralogists Special Publication, p. $97-122$.

Pollard, D.D., and Aydin, A., 1988 Progress in understanding jointing over the past century: Geological Society of America Bulletin, v. 100, p. 1181-1204.

Price, N.J., 1966, Fault and joint development in brittle and semibrittle rocks: Oxford, United Kingdom, Pergamon Press, 176 p.p.

Priest, S.D., and Hudson, J.A., 1976, Discontinuity spacings in rock: International Journal of Rock Mechanics and Mining Sciences and Geomechanical Abstracts, v. 13, p. $135-148$.

Priest, S.D., 1993, Fluid Flow in Discontinuities, in Discontinuity Analysis for Rock Engineering,: London, UK, Chapman and Hall, p. 340-381.

Pruess, S.A., 1995, Some remarks on the numerical estimation of fractal dimension, in Barton, C.C., and La Pointe, P.R., eds., Fractals in the earth sciences: New York, New York, Plenum Press, p.65-75.

Reed R.D., and Holister, J.S., 1936, Structural evolution of southern California: Tulsa, American Association of Petroleum Geologists, 157 p.p.

Renshaw, C.E., 1997, Mechanical controls on the spatial density of opening-mode fracture networks: Geology, v. 25, p. 923-926. 
Rohrbaugh, M.B., Dunne, W.M., and Mauldon, M., 2002, Estimting fracture trace intensity, density, and mean length using circular scanlines and windows: American Association of Petroleum Geologists, v. 86, p. 2089-2104.

Scott A., Kellog, K.S., Stanley, R.G., Stone, P., Powell, C.L., Gurrola, L.D., Selting A., J., and Brandt, T.R., 2001, U.S. Geological Survey Digital Map, scale 1:24000.

Shaw, J.H., and Suppe, J., 1994, Active faulting and growth folding in the eastern Santa Barbara Channel, California: Geological Society of America Bulletin, v. 106, p. 607-626.

Sibson, R.H., 1996, Structural permeability of fluid-driven fault-fracture meshes: Journal of Structural Geology, v. 18, p. 1031-1042.

Smith, L., and Schwartz, F.W., 1984, An analysis of the influence of fracture geometry on mass transport in fractured media: Water Resources Research, v. 20, p. 1241-1252.

Star, J., and Estes, J., 1990, Geographic information systems; an introduction: Englewood Cliffs, New Jersey, Prentice Hall, 503 p.p.

Stauffer, D., 1985, Introduction to percolation theory: London, UK, Taylor and Francis, 190 p.p.

Underwood, C.A., Cooke, M.L., Simnon, J.A., and Muldoon, M. A., 2003, Straigraphic controls on vertical fracture patterns in Silurian dolomite, northeastern Wisconsin: American Association of Petroleum Geologists bulletin, v. 87, p. 121-142.

Velde, B., Dubois, J., Touchard, G., Badri, A., 1990, Fractal analysis of fractures in rocks: the Cantor's dust method: Tectonophysics, v. 179, p. 345-352.

Voss, R.F., 1988, Random fractal forgeries, in Earnshaw, R.A., ed., Fundamental algorithms for computer graphics: Berlin, Springer-Verlag, p. 805-835.

Wilkins, S.J., 1999, The influence of mechanical layering on the evolution of brittle structures: fracture partitioning and fault growth in the Glen canyon sandstone, Split Mountain, Utah [Master's dissertation]: Miami, Florida, Florida International University, 209 p.p.

Wu, H., and Pollard, D.D., 1995, An experimental study of the relationship between joint spacing and layer thickness: Journal of structural geology, v. 17, p. 887-905.

Yerkes, R.F., 1985, Geologic and seismologic setting, in Ziony, J.I., ed., Evaluating Earthquake Hazards in the Los Angeles Region - An Earth Science Perspective: Prof. Pap. U.S. Geologocal Surv. 1360, p. 25-42. 
Zhang, X., and Sanderson, D.J., 1995, Anisotropic features of geometry and permability in fractured rock masses: Engineering Geology, v. 40, p. 65-75.

Zoback, M.D., Zoback, M.L., Mount, V.S., Suppe, J., Eaton, J., Healy, J.E., Oppenheimer, D., Reasenberg, P., Jones, L., Raleigh, C.B., Wong, I.G., Scotti, O., and Wentworth, C., 1987, New evidence on the state of stress of the San Andreas fault system: Science, v. 238, p. 1105-1111. 